Prepared in cooperation with the Eastern Nebraska Water Resources Assessment

\title{
Groundwater Quality and Age of Secondary Bedrock Aquifers in the Glaciated Portion of Eastern Nebraska, 2016-18
}

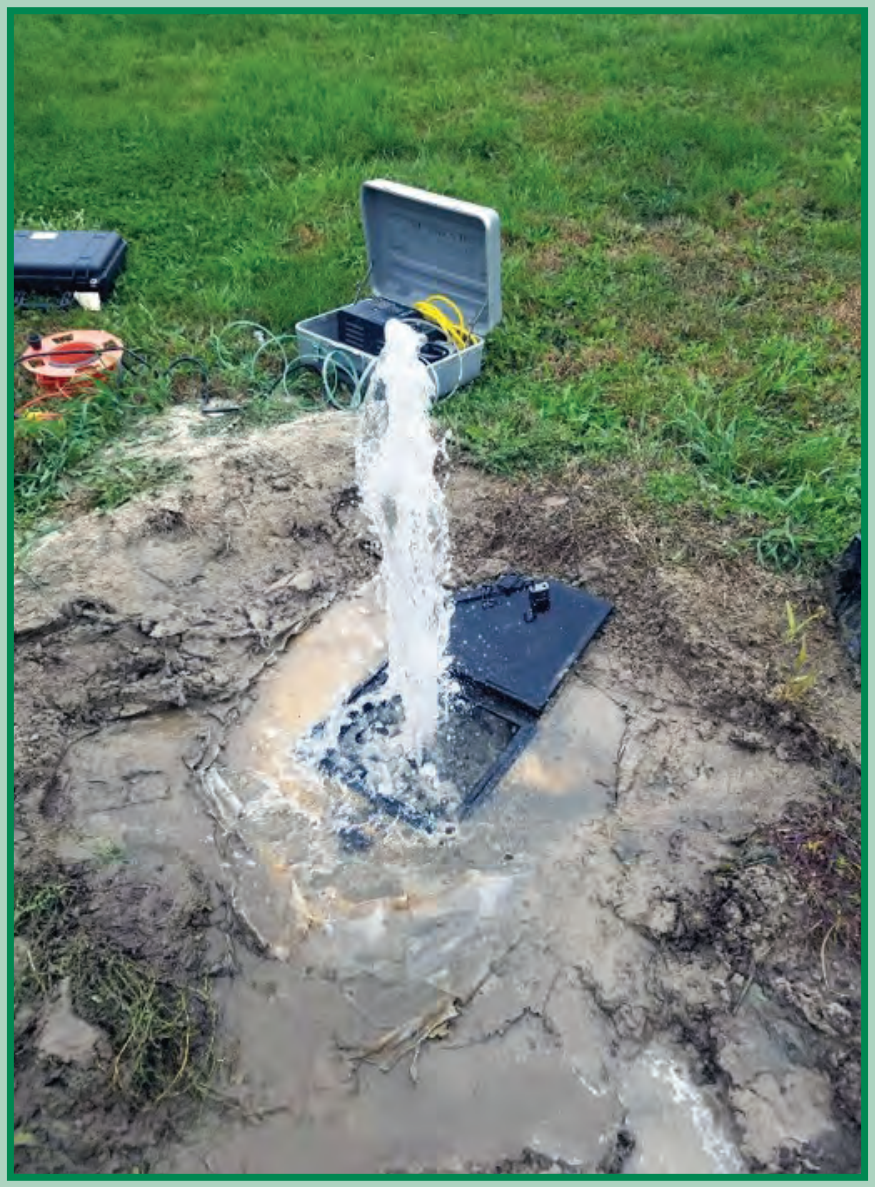

Scientific Investigations Report 2021-5055 
Front cover. Artesian well discharging groundwater from Dakota aquifer, Burt County, Nebraska, 2016. Photograph by Justin Krahulik, U.S. Geological Survey.

Back cover. U.S. Geological Survey hydrologists collecting a groundwater sample, Sarpy County, Nebraska, 2016. Photograph by Amanda Flynn, U.S. Geological Survey. 


\section{Groundwater Quality and Age of Secondary Bedrock Aquifers in the Glaciated Portion of Eastern Nebraska, 2016-18}

By Christopher M. Hobza and Amanda T. Flynn

Prepared in cooperation with the Eastern Nebraska Water Resources

Assessment

Scientific Investigations Report 2021-5055 


\section{U.S. Geological Survey, Reston, Virginia: 2021}

For more information on the USGS - the Federal source for science about the Earth, its natural and living resources, natural hazards, and the environment—visit https://www.usgs.gov or call 1-888-ASK-USGS.

For an overview of USGS information products, including maps, imagery, and publications, visit https://store.usgs.gov/.

Any use of trade, firm, or product names is for descriptive purposes only and does not imply endorsement by the U.S. Government.

Although this information product, for the most part, is in the public domain, it also may contain copyrighted materials as noted in the text. Permission to reproduce copyrighted items must be secured from the copyright owner.

Suggested citation:

Hobza, C.M., and Flynn, A.T., 2021, Groundwater quality and age of secondary bedrock aquifers in the glaciated portion of eastern Nebraska, 2016-18: U.S. Geological Survey Scientific Investigations Report 2021-5055, 42 p., https://doi.org/10.3133/sir20215055.

Associated data for this publication:

U.S. Geological Survey, 2019, USGS water data for the Nation: U.S. Geological Survey National Water Information System database, https://doi.org/10.5066/F7P55KJN.

ISSN 2328-0328 (online) 


\section{Acknowledgments}

The authors would like to thank the Eastern Nebraska Water Resources Assessment (ENWRA) coordinator Katie Cameron as well as the ENWRA technical committee for help with well selection and field logistics during sampling. The authors also would like to thank the managers of the Lewis and Clark, Lower Elkhorn, Lower Platte North, Lower Platte South, Nemaha, and Papio-Missouri River Natural Resources Districts for their financial and technical support. The authors also thank Sue Lackey with the University of Nebraska Conservation and Survey Division and Jim Cannia from Aqua Geo Frameworks for their technical expertise in well selection and interpreting airborne electromagnetic and test-hole data. 



\section{Contents}

Acknowledgments ..................................................................................................................ii

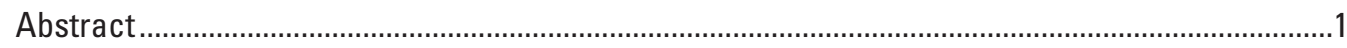

Introduction

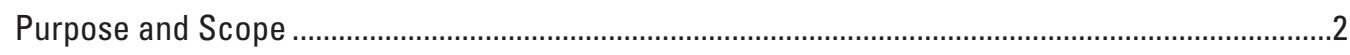

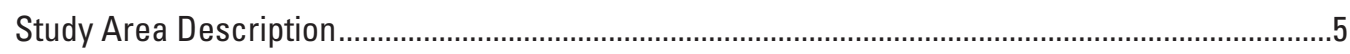

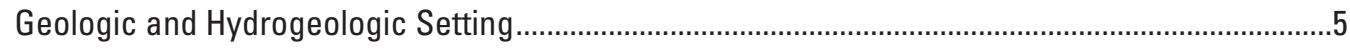

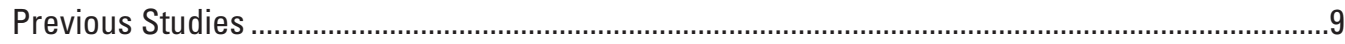

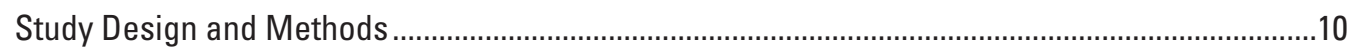

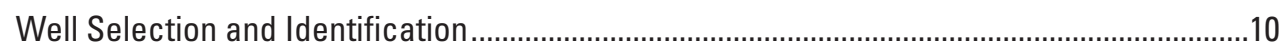

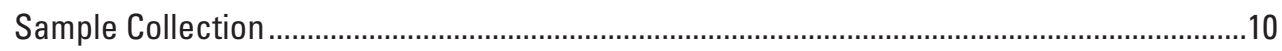

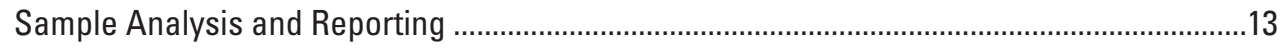

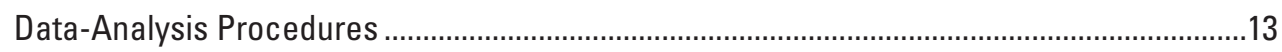

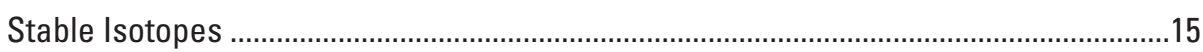

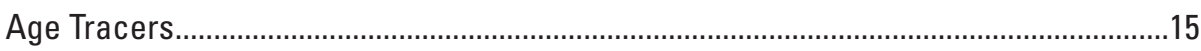

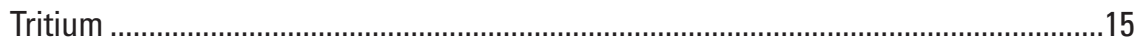

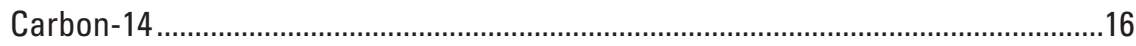

Quality Assurance and Quality Control .............................................................................16

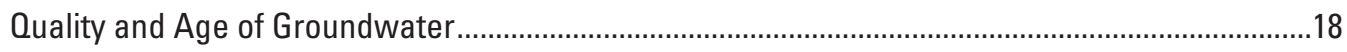

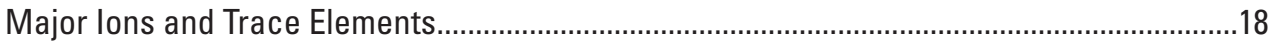

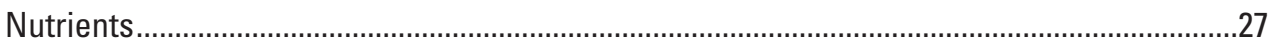

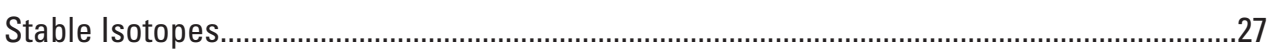

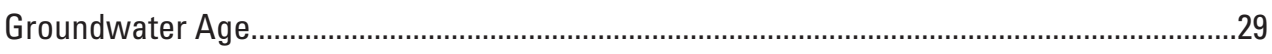

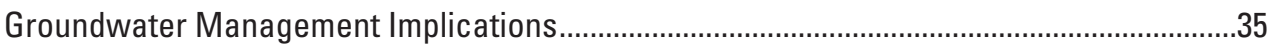

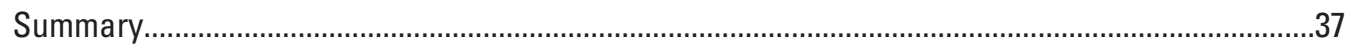

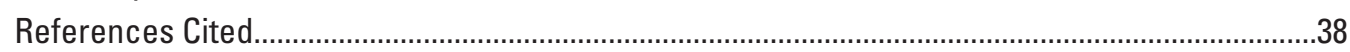




\section{Figures}

1. Map showing the Eastern Nebraska Water Resources Assessment study area and location of sampled wells, eastern Nebraska.. 3

2. Map showing bedrock geology and location of sampled wells, eastern Nebraska .........4

3. Piper diagram showing ionic composition of groundwater from Dakota aquifer, Niobrara aquifer, and Paleozoic aquifers, eastern Nebraska, 2016-18.

4. Map showing dominant water type for wells completed in the Dakota aquifer, Niobrara aquifer, and Paleozoic aquifers, eastern Nebraska, 2016-18

5. Graphs showing concentrations from sampled wells against well depth, eastern Nebraska, 2016-18.

6. Graph showing stable isotopes of oxygen and hydrogen from sampled wells, eastern Nebraska, 2016-18

7. Graph showing concentrations of carbon-14, in percent Modern Carbon, against well depth, eastern Nebraska, 2016-18

8. Map showing radiocarbon ages, in years before present, from sampled wells, eastern Nebraska, 2016-18

9. Graph showing concentrations of tritium against well depth, eastern Nebraska, 2016-18

10. Map showing tritium age category from sampled wells, eastern Nebraska, 2016-18 ...36

\section{Tables}

1. Description of geologic and hydrostratigraphic units, eastern Nebraska

2. Sampled well location, date sampled, completion information, and sampled aquifer, eastern Nebraska, 2016-18

3. Laboratory analytical methods and field preservation procedures for water-quality constituents

4. Selected statistics of field blank samples and relative percent difference between replicate samples, eastern Nebraska, 2016-18

$5 A$. Results of water-quality analyses for selected constituents, eastern Nebraska, 2016-18.

$5 B$. Results of water-quality analyses for selected constituents, eastern Nebraska, 2016-18.

6. Results from the Krustal-Wallis and Wilcoxon Rank Sum statistical tests for selected field properties and constituents.

7. Calculated radiocarbon ages and tritium age categories from sampled wells, eastern Nebraska, 2016-18 


\section{Conversion Factors}

U.S. customary units to International System of Units

\begin{tabular}{lcl}
\hline & Multiply & \multicolumn{1}{c}{ To obtain } \\
\hline inch (in.) & Length & \\
inch (in.) & 2.54 & centimeter $(\mathrm{cm})$ \\
foot (ft) & 25.4 & millimeter $(\mathrm{mm})$ \\
mile (mi) & 0.3048 & meter $(\mathrm{m})$ \\
\hline & 1.609 & kilometer $(\mathrm{km})$ \\
\hline acre & Area & \\
acre & 4,047 & square meter $\left(\mathrm{m}^{2}\right)$ \\
acre & 0.4047 & hectare $($ ha) \\
acre & 0.4047 & square hectometer $\left(\mathrm{hm}{ }^{2}\right)$ \\
\hline & 0.004047 & square kilometer $\left(\mathrm{km}{ }^{2}\right)$ \\
\hline gallon (gal) & Volume & \\
gallon (gal) & 3.785 & liter $(\mathrm{L})$ \\
gallon (gal) & 0.003785 & cubic meter $\left(\mathrm{m}^{3}\right)$ \\
\hline & 3.785 & cubic decimeter $\left(\mathrm{dm}{ }^{3}\right)$ \\
\hline gallon per minute $(\mathrm{gal} / \mathrm{min})$ & Flow rate & \\
inch per year (in/yr) & 0.06309 & liter per second $(\mathrm{L} / \mathrm{s})$ \\
\hline & 25.4 & millimeter per year $(\mathrm{mm} / \mathrm{yr})$ \\
\hline picocurie per liter (pCi/L) & Radioactivity & \\
\hline
\end{tabular}

Temperature in degrees Celsius $\left({ }^{\circ} \mathrm{C}\right)$ may be converted to degrees Fahrenheit $\left({ }^{\circ} \mathrm{F}\right)$ as follows:

$$
{ }^{\circ} \mathrm{F}=\left(1.8 \times{ }^{\circ} \mathrm{C}\right)+32 .
$$

Temperature in degrees Fahrenheit $\left({ }^{\circ} \mathrm{F}\right)$ may be converted to degrees Celsius $\left({ }^{\circ} \mathrm{C}\right)$ as follows:

$$
{ }^{\circ} \mathrm{C}=\left({ }^{\circ} \mathrm{F}-32\right) / 1.8 \text {. }
$$

\section{Datum}

Vertical coordinate information is referenced to the North American Vertical Datum of 1988 (NAVD 88).

Horizontal coordinate information is referenced to the North American Datum of 1983 (NAD 83).

Elevation, as used in this report, refers to distance above the vertical datum. 


\section{Supplemental Information}

Specific conductance is given in microsiemens per centimeter at 25 degrees Celsius $(\mu \mathrm{S} / \mathrm{cm}$ at $\left.25^{\circ} \mathrm{C}\right)$.

Concentrations of chemical constituents in water are given in either milligrams per liter (mg/L) or micrograms per liter ( $\mu \mathrm{g} / \mathrm{L})$.

Activities for radioactive constituents in water are given in picocuries per liter (pCi/L).

Results for measurements of stable isotopes of an element (with symbol E) in water, solids, and dissolved constituents commonly are expressed as the relative difference in the ratio of the number of the less abundant isotope (iE) to the number of the more abundant isotope of a sample with respect to a measurement standard.

\section{Abbreviations}

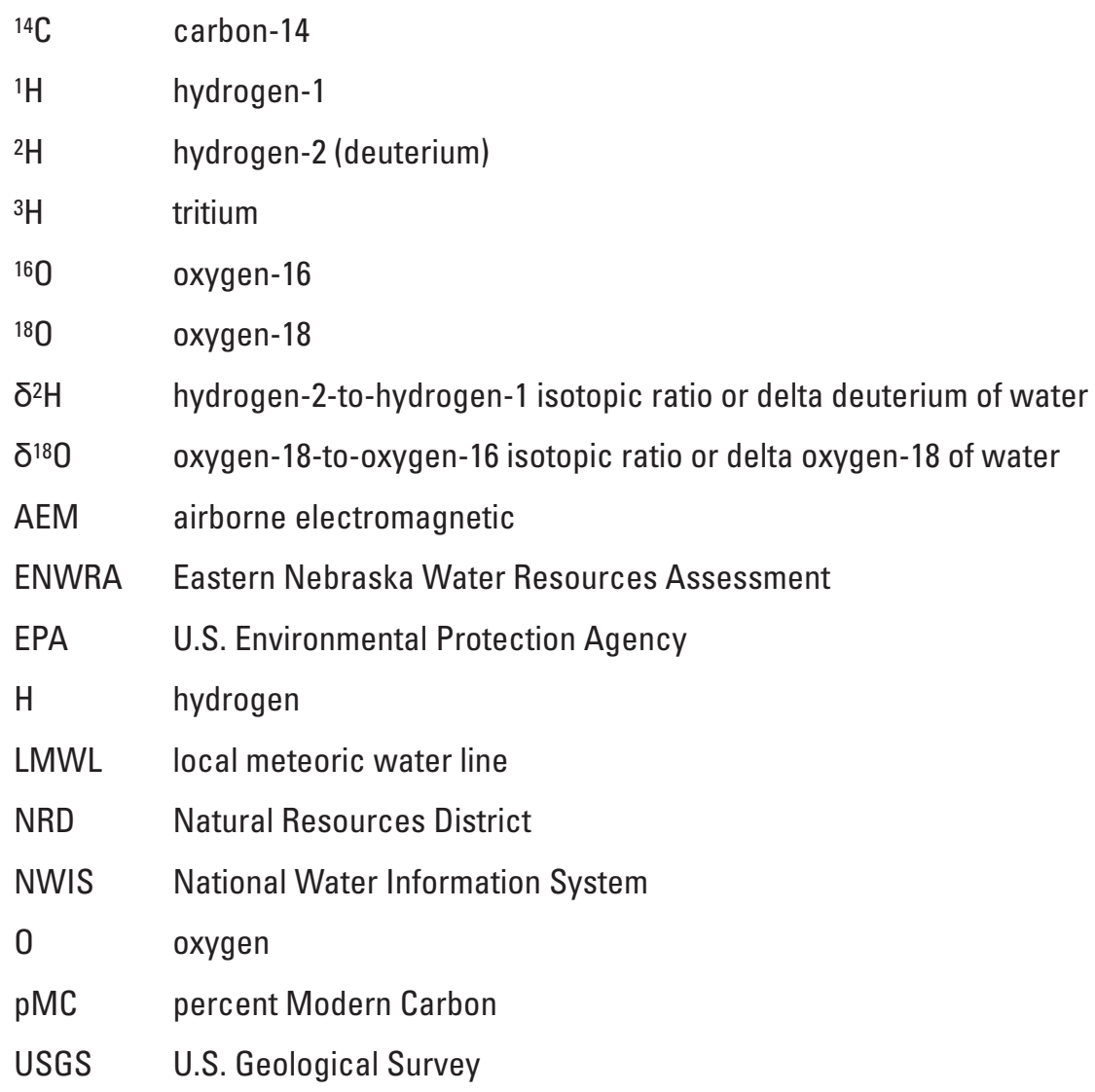




\title{
Groundwater Quality and Age of Secondary Bedrock Aquifers in the Glaciated Portion of Eastern Nebraska, 2016-18
}

\author{
By Christopher M. Hobza and Amanda T. Flynn
}

\section{Abstract}

The Eastern Nebraska Water Resources Assessment (ENWRA) project was initiated in 2006 to assist water managers by developing a hydrogeologic framework and water budget for the glaciated portion of eastern Nebraska. Within the ENWRA area, the primary groundwater sources for municipal, domestic, and irrigation water needs are provided by withdrawals from alluvial, buried paleovalley, and the High Plains aquifer (where present). Generally, other bedrock aquifers are considered a secondary water source. However, in some areas, such as parts of Sarpy and Nemaha Counties, these secondary bedrock aquifers are the only source of water within glaciated upland areas. To improve the understanding of the quality, geochemistry, and age of groundwater from bedrock aquifers, the U.S. Geological Survey (USGS), in cooperation with the ENWRA group, which includes the Lewis and Clark, Lower Elkhorn, Lower Platte North, Lower Platte South, Nemaha, and Papio-Missouri River Natural Resources Districts, designed a study to sample 31 wells completed in the secondary bedrock aquifers and analyze samples for major ions, physical properties, nutrients, stable isotopes, and selected age tracers. Of the 31 samples collected for this report, 22 samples were collected from the Dakota aquifer contained in the Dakota Sandstone, 3 from the Niobrara aquifer contained in the Niobrara Formation of Colorado Group, and 6 from Paleozoic aquifers contained in undifferentiated Paleozoicage units.

The results of this study indicate that major ion data collected from the Dakota aquifer can be used for assessing the quality, recharge source, and age of groundwater. Calcium bicarbonate dominant samples were characterized as modern or mixed, indicating that, in these areas, groundwater is unconfined and is recharged by precipitation and (or) surface water. If groundwater extraction rates exceed recharge rates, total dissolved solid concentrations may increase as a result of upwelling of groundwater from deeper units or formations, which can adversely affect groundwater quality. Sampling results presented in this report indicate water quality is good, but that groundwater in the Dakota aquifer with calcium bicarbonate water type may be vulnerable to surface contamination.
In contrast, groundwater sampled from the Dakota aquifer, having a dominant water type other than calcium bicarbonate, generally has low dissolved oxygen and nitrate concentrations, and higher concentrations of total dissolved solids and trace elements, including iron and strontium. The geochemical characteristics of noncalcium bicarbonate samples from the Dakota aquifer indicated confining conditions and limited groundwater recharge from local precipitation. Apparent groundwater ages estimated from radiocarbon (carbon-14) sampling of noncalcium bicarbonate samples from the Dakota aquifer indicated that the time of groundwater recharge to the Dakota aquifer occurred during Pleistocene time. Depleted stable isotopes results indicate recharge during a colder climate. Groundwater under confined conditions is not easily recharged from precipitation or surface water. Future groundwater-level monitoring in locations where the Dakota aquifer appears to be confined could provide information to evaluate whether groundwater supplies remain sufficient to meet future municipal, domestic, and irrigation needs.

For the Niobrara aquifer and Paleozoic aquifers, the dominant water type was not a diagnostic indicator of recharge source, age, and groundwater quality as with the Dakota aquifer. Most likely this is because the host formation was dominated by calcium-carbonate-rich rocks; however, few samples were collected from these aquifers to be able to confirm this interpretation. Samples collected from wells completed in the Niobrara aquifer and Paleozoic aquifers and characterized as calcium sulfate water type have statistically significantly higher concentrations of total dissolved solids compared to other samples from the Niobrara aquifer and Paleozoic aquifers characterized as calcium bicarbonate. Given that six of the nine of samples collected from the Niobrara and Paleozoic aquifers indicated modern recharge, these secondary bedrock aquifers are reliant on precipitation to sustain groundwater levels and may be vulnerable to a multiyear drought. Well yields of the Niobrara and Paleozoic aquifers are dependent on the presence of secondary porosity and these units offer little storage. Samples collected from wells completed in Paleozoic aquifers were the most isotopically enriched and similar to modern precipitation and had the highest concentrations of nitrate, indicating that groundwater is affected by agricultural 
activities. Future groundwater sampling would be beneficial to characterize groundwater-quality changes within the Niobrara and Paleozoic aquifers over time.

\section{Introduction}

The Eastern Nebraska Water Resources Assessment (ENWRA) project was initiated to assist water managers by developing a hydrogeologic framework and water budget for the area of eastern Nebraska overlain by glacial deposits (Divine and others, 2009). The ENWRA area (fig. 1) covers more than 8,000,000 acres across the Lewis and Clark, Lower Elkhorn, Lower Platte North, Lower Platte South, Nemaha, and Papio-Missouri River Natural Resources Districts (NRDs) and roughly coincides with the extent of glacial till within Nebraska (fig. 2). Since 2007, airborne electromagnetic (AEM) geophysical surveys have been a focus of ENWRA to map the extents and characteristics of aquifers for groundwater resource assessments, better understand vulnerability of aquifers to surface contamination, and examine the connectivity of groundwater and surface water (Smith and others, 2008; Divine and others, 2009; Carney and others, 2015a, $2015 b)$. The AEM geophysical surveys generally have focused on mapping the alluvial, buried paleovalley; upland area; and bedrock aquifers (Divine and others, 2009). However, in 2014, widely spaced reconnaissance flights collected AEM data for deeper Paleozoic- and Cretaceous-age geologic units and bedrock aquifers (Carney and others, 2015a, 2015b).

Municipal, domestic, and irrigation water needs in the ENWRA area are primarily met from alluvial and buried paleovalley aquifers and the High Plains aquifer within Nebraska, and generally, other bedrock aquifers are considered a secondary water source (Divine and Sibray, 2017); however, in some ENWRA areas, such as parts of Sarpy and Nemaha Counties, bedrock aquifers are the only source of water within the upland areas overlain by glacial deposits (Divine and Sibray, 2017). Within eastern Nebraska, population growth has led to increased development of groundwater resources for domestic and municipal needs (Maupin and others, 2014; Dieter and others, 2018). Groundwater pumping for irrigation during recent droughts $(2000-6$; 2012) has reduced streamflows and strained drinking-water supplies for some towns and cities (Laukaitis, 2012). In response to some of these concerns, water resource managers have been evaluating the use of secondary bedrock aquifers to meet future municipal and domestic-water needs. The AEM surveys and subsequent hydrostratigraphic interpretation have filled an important data gap by mapping the extents and lithologic characteristics of bedrock aquifers within eastern Nebraska; however, the quality, chemical characteristics, and age of groundwater within secondary bedrock aquifers have not been adequately characterized. Unconfined bedrock aquifers that are in hydrologic connection to surface water or surficial alluvial aquifers may receive adequate recharge to handle additional development, but the aquifer also can be vulnerable to surface contamination. Conversely, confined bedrock aquifers generally have lower recharge rates and, therefore, are potentially sensitive to increased groundwater development. To improve the understanding of the quality, geochemistry, and age of groundwater from bedrock aquifers, the U.S. Geological Survey (USGS), in cooperation with the ENWRA group, which includes the Lewis and Clark, Lower Elkhorn, Lower Platte North, Lower Platte South, Nemaha, and Papio-Missouri River NRDs, designed a study to sample 31 wells completed in the secondary bedrock aquifer and analyze samples for major ions, physical properties, nutrients, stable isotopes, and selected age tracers. The interpretation of these sampling results can provide water resource managers with additional information regarding the quality, age, and sustainability of secondary bedrock aquifers within eastern Nebraska, which are needed for future water resource planning and management.

\section{Purpose and Scope}

The purpose of this report is to characterize the quality, geochemistry, and age of groundwater in selected secondary bedrock aquifers in the ENWRA area of eastern Nebraska. Samples were collected from 31 existing monitoring, domestic, and stock wells for major ions, physical properties, nutrients, stable isotopes, and selected age tracers. Of the 31 samples collected for this report, 22 samples were collected from wells completed in the Dakota aquifer (also known as the Maha aquifer; Korus and Joeckel, 2011), which is contained in Early Cretaceous-age Dakota Sandstone, 3 from wells completed in the Niobrara aquifer contained in Late Cretaceousage Niobrara Formation of Colorado Group, and 6 from wells completed in Paleozoic aquifers contained in undifferentiated Paleozoic units. The proportion of samples used in this study roughly reflects the proportion of water use of these bedrock aquifers, with the Dakota aquifer being the most widely used of the aquifers sampled. The groundwater sampling approach and well selection process is described in the "Well Selection and Identification" section of this report. The results and interpretations from this study supplement the findings from previous studies by including additional sampling locations and constituents and providing a more current assessment of groundwater-quality conditions. Constituent concentrations from each of the sampled aquifer were compared with current U.S. Environmental Protection Agency (EPA) drinking-water regulations (U.S. Environmental Protection Agency, 2018) and assessed by aquifer. This report also summarizes interpretations from stable isotope and age tracer sampling and analyses from the 31 wells sampled. 


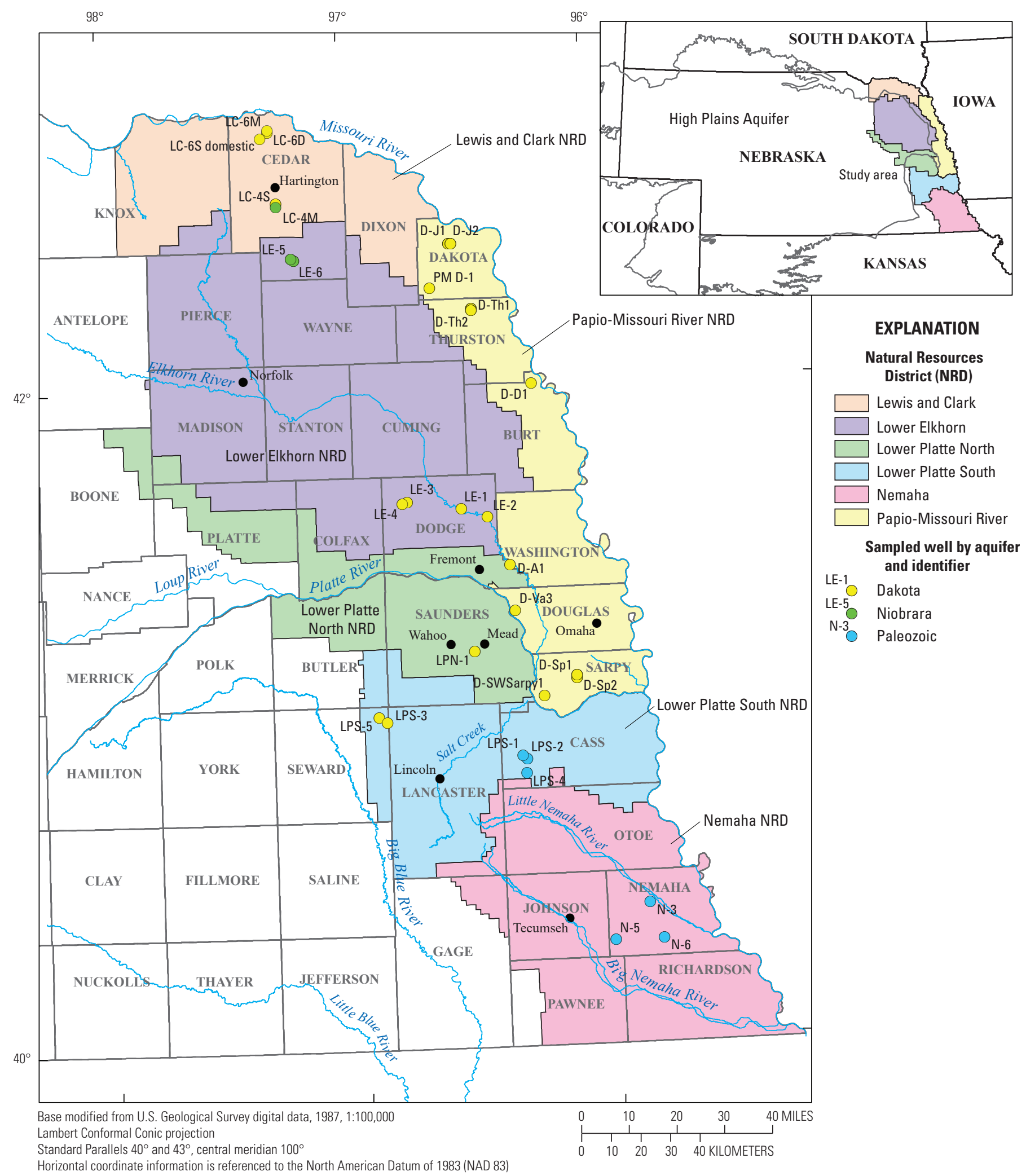

Figure 1. The Eastern Nebraska Water Resources Assessment (ENWRA) study area and location of sampled wells, eastern Nebraska. 


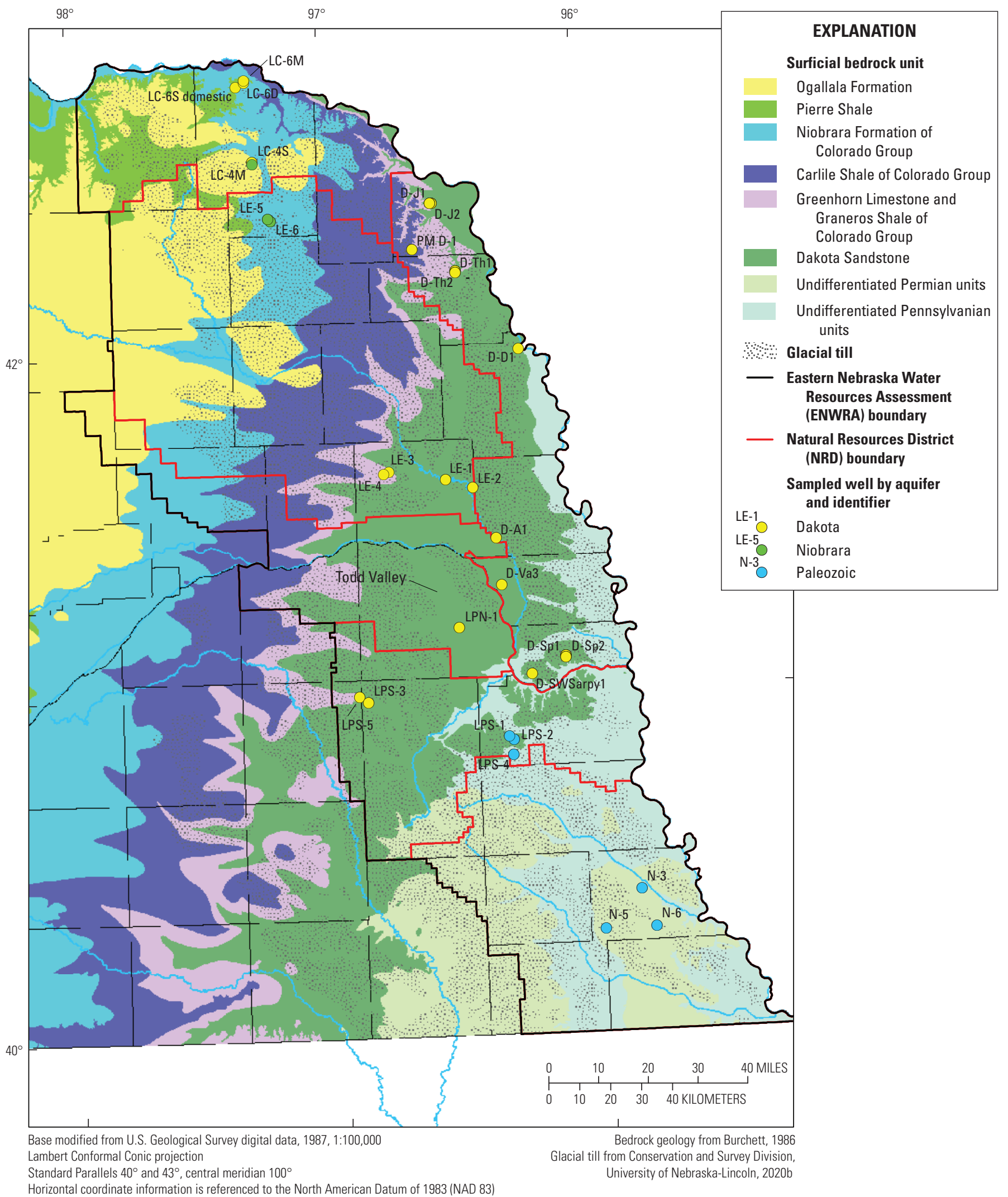

Figure 2. Bedrock geology and location of sampled wells, eastern Nebraska. 


\section{Study Area Description}

The study area for this report is the ENWRA area, which includes the Lewis and Clark, Lower Elkhorn, Lower Platte North, Lower Platte South, Nemaha, and Papio-Missouri River NRDs (fig. 1). The western boundary of the study area roughly coincides with the western extent of glacial till and overlaps onto the eastern margin of the High Plains aquifer (figs. 1 and 2). The study area is bounded by the Missouri River on the north and east and by the Kansas border to the south (fig. 1). The major streams of the study area include the Platte River, which flows from west to east across the center of the study area; the Elkhorn River, which is the largest tributary of the Platte River and flows southeast across the northern part of the study area to its confluence with the Platte River, south of Fremont, Nebraska; and the Little Nemaha and Big Nemaha Rivers, which drain the southern part of the study area (fig. 1).

Much of the study area is at the western edge of the Central Lowlands physiographic province (not shown on any maps) and is characterized as dissected till plains; however, the western parts of the Lewis and Clark, Lower Elkhorn, and Lower Platte North NRDs (fig. 1) are along the eastern margin of the Great Plains physiographic province (not shown on any maps; Fenneman and Johnson, 1946). The study area consists of gently rolling to steep upland areas that flank the major streams within the study area (Conservation and Survey Division, University of Nebraska-Lincoln, 2020c). The upland areas consist of loess-covered glacial deposits that can be deeply dissected by numerous small drainages (Verstraeten and Ellis, 1995; Druliner and Mason, 2000).

The climate in the study area is typical of continental midlatitude locations, characterized by cold winters and warm summers (National Center for Environmental Information, 2020). From 1981 to 2010, at Fremont, Nebr. (fig. 1), the average annual low temperature for the winter was -9.2 degrees Celsius $\left({ }^{\circ} \mathrm{C}\right)$ and the average annual high temperature was $28.4{ }^{\circ} \mathrm{C}$ (National Center for Environmental Information, 2020). During that same period, the average annual precipitation was 30 inches per year (National Center for Environmental Information, 2020). In the study area, nearly 75 percent of the annual precipitation falls from April through September (National Center for Environmental Information, 2020), which is considered to be the growing season for crops.

In the study area, most of the land is used for agricultural purposes (Center for Advanced Land Management Information Technologies, 2007). Approximately 48 percent of the study area is classified as dryland cropland; 28 percent pasture; 13 percent irrigated crops; 7 percent open water, riparian woodlands, and wetlands; and 4 percent urbanized (Center for Advanced Land Management Information Technologies, 2007).

\section{Geologic and Hydrogeologic Setting}

This section of the report describes the geologic setting and hydrogeology of the study area. Geologic units important to the groundwater flow system are discussed with special attention applied to sampled bedrock aquifers and with limited discussion of overlying surficial units. The ages and geologic and hydrogeologic characteristics of geologic and hydrostratigraphic units, including the sampled bedrock aquifers, are described in table 1 . The sampled bedrock aquifers within the study area are contained in geologic units that can be generally categorized as either Paleozoic or Cretaceous in age (fig. 2, table 1; Burchett, 1986). Bedrock formations generally have a subcrop along a northeast to southwest trendline with younger units to the western part of the study area and older units to the south and east (fig. 2).

Undifferentiated Pennsylvanian- and Permian-age units have subcrops in the Nemaha and the Lower Platte South NRDs in southeast part of the study area and to the east along the Missouri River valley in the Papio-Missouri River NRD (Burchett, 1986; Divine, 2014; fig. 2). For the purposes of this report, surficial Pennsylvanian- and Permian-age units described here are described as "aquitards with local lowyield aquifers" by Korus and Joeckel (2011) and are referred to hereinafter as "Paleozoic aquifers" and overlie the Western Interior Plains aquifer system (table 1). Pennsylvanian units are described as predominantly shale or interbedded limestone and are semi-confined or confined (Tanner and Steele, 1991). Permian-age units are described as limestone, shale, mudstone, and evaporites and are unconfined to semi-confined (table 1; Korus and Joeckel, 2011). Wells completed in the Paleozoic aquifers can yield up to 20 to 50 gallons per minute (gal/min) and yields are dependent on fracturing and the development of secondary porosity (Tanner and Steele, 1991). Water use for the Paleozoic aquifers is generally limited to domestic or stock wells (Korus and Joeckel, 2011).

Cretaceous-age units cover much of the study area and include the Dakota Sandstone (also called the Dakota Group), Greenhorn Limestone of Colorado Group, Graneros Shale of Colorado Group, Carlile Shale of Colorado Group, Niobrara Formation of Colorado Group, and Pierre Shale (fig. 2; Korus and Joeckel, 2011). In the study area, the oldest of these units and most hydrologically important is the Dakota Sandstone. The Dakota Sandstone was deposited 100 to 145 million years ago along the margin of the Western Interior Seaway (not shown on any maps). Within the study area, the Dakota Sandstone is described as a highly variable series of sandstones, shales, siltstones, and mudstones that reflect a complex pattern of deposition and erosion that are associated with fluvial, near-shore, and beach depositional environments (table 1; Gosselin and others, 2001). The Dakota Sandstone covers a large geographic area, which includes large parts of Nebraska, Kansas, and Colorado, and has highly variable 
Table 1. Description of geologic and hydrostratigraphic units, eastern Nebraska.

[Ma, millions of years ago; NRD, Natural Resources District; gal/min, gallon per minute; mg/L, milligram per liter]

\begin{tabular}{|c|c|c|c|c|c|c|c|}
\hline Period & Epoch & Age (Ma) & Geologic unit & $\begin{array}{c}\text { Geologic } \\
\text { description } 1\end{array}$ & \multicolumn{2}{|c|}{ Hydrostratigraphic unit } & Hydrogeologic description ${ }^{1}$ \\
\hline \multirow[b]{2}{*}{ Quaternary } & Holocene & Present to 0.01 & \multirow{2}{*}{$\begin{array}{l}\text { Undifferentiated } \\
\text { Quaternary } \\
\text { deposits }\end{array}$} & \multirow{2}{*}{$\begin{array}{l}\text { Loess, till, eolian } \\
\text { sand, and alluvial } \\
\text { deposits }\end{array}$} & \multirow{3}{*}{$\begin{array}{l}\text { High } \\
\text { Plains } \\
\text { aquifer } \\
\text { system }\end{array}$} & $\begin{array}{c}\text { Alluvial and eolian } \\
\text { deposits }\end{array}$ & $\begin{array}{l}\text { Primary water source for much of study area, located } \\
\text { along major river and stream valleys including the } \\
\text { Platte River, Elkhorn River, and Big Nemaha River. }\end{array}$ \\
\hline & Pleistocene & 0.01 to 2.6 & & & & Paleovalley aquifers & $\begin{array}{l}\text { Coarse sediments deposited from eastward drain- } \\
\text { ing Pleistocene-age streams in eroded valleys in } \\
\text { exposed bedrock, often capped with glacial till, } \\
\text { primary water source where present. }\end{array}$ \\
\hline Tertiary & Miocene & 5.3 to 19 & Ogallala Formation & $\begin{array}{l}\text { Poorly sorted mixture } \\
\text { of sand, silt, clay, } \\
\text { gravel, sandstone, } \\
\text { and siltstone }\end{array}$ & & Ogallala aquifer & $\begin{array}{l}\text { Moderate- to high-yielding water-bearing units. } \\
\text { Heterogeneous mix of sand, silt, gravel, sandstone, } \\
\text { and clay. Yields vary greatly by locality. Principal } \\
\text { aquifer in western parts of the Lower Elkhorn and } \\
\text { Lewis and Clark NRDs. }\end{array}$ \\
\hline \multirow{5}{*}{ Cretaceous } & \multirow{4}{*}{$\begin{array}{c}\text { Upper } \\
\text { Cretaceous }\end{array}$} & \multirow{4}{*}{65 to 99.6} & Pierre Shale & $\begin{array}{l}\text { Gray to black marine } \\
\text { shale }\end{array}$ & \multicolumn{2}{|c|}{ Pierre Shale confining unit } & Confining unit, not a source of water. \\
\hline & & & $\begin{array}{l}\text { Niobrara Formation } \\
\text { of the Colorado } \\
\text { Group }\end{array}$ & $\begin{array}{l}\text { Shaley chalk, lime- } \\
\text { stone }\end{array}$ & \multicolumn{2}{|c|}{ Niobrara aquifer ${ }^{2}$} & $\begin{array}{l}\text { Secondary bedrock aquifer. Largest concentration of } \\
\text { wells is in Cedar County where well yields aver- } \\
\text { age } 400 \text { gal } / \mathrm{min} \text {, also a water source in Pierce and } \\
\text { Madison Counties, where fractured. }\end{array}$ \\
\hline & & & $\begin{array}{l}\text { Carlile Shale of the } \\
\text { Colorado Group }\end{array}$ & $\begin{array}{l}\text { Shale with minor } \\
\text { limestone }\end{array}$ & \multicolumn{2}{|c|}{ Carlile Shale confining unit } & $\begin{array}{l}\text { Predominantly shale, part of Great Plains confin- } \\
\text { ing system, but includes a sandstone unit in Knox } \\
\text { County, which is called the Codell aquifer (Miller } \\
\text { and Appel, 1997; Divine and Sibray, 2017). }\end{array}$ \\
\hline & & & $\begin{array}{l}\text { Greenhorn } \\
\text { Limestone and } \\
\text { Graneros Shale of } \\
\text { the Colorado Group }\end{array}$ & Limestone and shale & \multicolumn{2}{|c|}{$\begin{array}{l}\text { Greenhorn Limestone and } \\
\text { Graneros Shale confining unit }\end{array}$} & $\begin{array}{l}\text { Not typically used as a water source, part of Great } \\
\text { Plains confining system (Miller and Appel, 1997) }\end{array}$ \\
\hline & $\begin{array}{c}\text { Lower } \\
\text { Cretaceous }\end{array}$ & 99.6 to 145.5 & Dakota Sandstone & $\begin{array}{l}\text { Sandstone, with } \\
\text { intervals of } \\
\text { interbedded shale } \\
\text { and mudstone }\end{array}$ & \multicolumn{2}{|c|}{ Dakota aquifer $^{2}$} & $\begin{array}{l}\text { Unconfined to confined, wells can yield up to } 750 \\
\text { gal/min in northeast Nebraska, most widely used } \\
\text { bedrock aquifer in eastern Nebraska. The Dakota } \\
\text { aquifer, which is also called the Maha aquifer, is } \\
\text { the uppermost aquifer of the Great Plains aquifer } \\
\text { system; the underlying aquifer in the Great Plains } \\
\text { aquifer system is the Apishapa aquifer, which is not } \\
\text { present in the study area (Miller and Appel, 1997). }\end{array}$ \\
\hline
\end{tabular}


Table 1. Description of geologic and hydrostratigraphic units, eastern Nebraska.-Continued

[Ma, millions of years ago; NRD, Natural Resources District; gal/min, gallon per minute; mg/L, milligram per liter]

\begin{tabular}{|c|c|c|c|c|c|c|}
\hline Period & Epoch & Age (Ma) & Geologic unit & $\begin{array}{c}\text { Geologic } \\
\text { description }\end{array}$ & Hydrostratigraphic unit & Hydrogeologic description ${ }^{1}$ \\
\hline Permian & & 245 to 286 & $\begin{array}{l}\text { Undifferentiated } \\
\text { Permian units }\end{array}$ & $\begin{array}{l}\text { Limestone, shale, } \\
\text { mudstone, and } \\
\text { evaporites }\end{array}$ & \multirow{2}{*}{ Paleozoic aquifers ${ }^{2}$} & \multirow{2}{*}{$\begin{array}{l}\text { Able to supply water to domestic and stock wells, } \\
\text { yield depends on degree of fracturing. }\end{array}$} \\
\hline Pennsylvanian & & 286 to 318 & $\begin{array}{c}\text { Undifferentiated } \\
\text { Pennsylvanian units }\end{array}$ & $\begin{array}{l}\text { Limestone, shale, } \\
\text { mudstone, and } \\
\text { sandstone }\end{array}$ & & \\
\hline Mississippian & & 318 to 359 & \multirow{5}{*}{$\begin{array}{l}\text { Multiple } \\
\text { undifferentiated } \\
\text { units }\end{array}$} & \multirow{5}{*}{$\begin{array}{l}\text { Limestone, sandy } \\
\text { limestone, } \\
\text { dolomite, silty } \\
\text { dolomite, shaly } \\
\text { dolomite, shale, } \\
\text { siltstone, and chert }\end{array}$} & \multirow{5}{*}{$\begin{array}{l}\text { Western Interior Plains aquifer } \\
\text { system }\end{array}$} & \multirow{5}{*}{$\begin{array}{l}\text { Secondary aquifers with poor water quality, water is } \\
\text { saline to brine with estimated total dissolved solid } \\
\text { concentrations ranging from } 11,000 \text { to } \\
200,000 \mathrm{mg} / \mathrm{L} \text {. }\end{array}$} \\
\hline Devonian & & 359 to 416 & & & & \\
\hline Silurian & & 416 to 444 & & & & \\
\hline Ordovician & & 444 to 488 & & & & \\
\hline Cambrian & & 488 to 542 & & & & \\
\hline
\end{tabular}

${ }^{1}$ Geologic and hydrogeologic descriptions modified from Korus and Joeckel (2011), Divine and Sibray (2017), and Tanner and Steele (1991).

${ }^{2}$ Sampled secondary bedrock aquifer. 
lithologic characteristics. The stratigraphic and hydrostratigraphic organization of this unit varies by state and location. The Dakota Sandstone hosts the Great Plains aquifer system, which is composed of the hydrostratigraphically distinct Maha and Apishapa aquifers (Helgesen and others, 1993). Within eastern Nebraska, only the Maha aquifer is present (Helgesen and others, 1993). In Nebraska, the Maha aquifer is locally referred to as the Dakota Sandstone or Dakota aquifer (Divine, 2014); in this report the Maha aquifer will hereinafter be referred to as the Dakota aquifer. Helgesen and others (1993) reported that more than 75 percent of the Dakota Sandstone thickness is described as a sandstone in the southern part of the study area, compared with only 50 percent for the northern part of the study area.

The Dakota aquifer is the most widely used secondary bedrock aquifer within eastern Nebraska. As of 2015 there were approximately 3,400 registered wells completed within the Dakota aquifer (Divine and Sibray, 2017). The Dakota aquifer is often relied on for domestic purposes where nearly 75 percent of the registered wells are used for domestic purposes. Since 1993, the number of registered domestic wells screened in the Dakota aquifer has increased by approximately 130 per year (Divine and Sibray, 2017). Most of the Dakota aquifer wells are located along the southwest to northeast belt from southwestern Lancaster County into Sarpy and Douglas Counties (fig. 1). Well completed within the Dakota aquifer are also concentrated within counties that border the Missouri River upstream from Douglas County (Divine and Sibray, 2017). Quaternary-age deposits directly overlie the Dakota aquifer along both of these locations. Roughly 10 percent of wells completed in the Dakota aquifer are located west of the subcrop belt where Late Cretaceous-age shales overlie the Dakota aquifer and restrict its recharge from precipitation. In Cedar County in the Lewis and Clark NRD (fig. 2), well yields can exceed $750 \mathrm{gal} / \mathrm{min}$, which are the highest yields for any well completed in the Dakota aquifer (Divine and Sibray, 2017).

Overlying the Dakota aquifer are the Greenhorn Limestone and the Graneros Shale of the Colorado Group and the Carlile Shale of the Colorado Group (table 1). The Greenhorn Limestone and the Graneros Shale of the Colorado Group units are not used as a water source across the study area and are part of the Great Plains confining system (Miller and Appel, 1997). The Carlile Shale of the Colorado Group is also part of the Great Plains confining system (Miller and Appel, 1997), is predominantly shale and, in parts of Boyd and Knox Counties, hosts the Codell aquifer, which is composed of a sandstone unit (Divine and Sibray, 2017).

The Niobrara Formation of the Colorado Group is locally described as a shaley chalk or limestone and hosts the Niobrara aquifer (table 1; Korus and Joeckel, 2011). The largest concentration of wells completed in the Niobrara aquifer is in Cedar County in the Lewis and Clark NRD (fig. 2; Divine and Sibray, 2017). Within Cedar County, approximately half of the 150 registered wells, which are screened in the Niobrara aquifer, are irrigation wells that on average can yield more than $400 \mathrm{gal} / \mathrm{min}$ (Divine and Sibray, 2017). In some locations, where fractures are present, such as in Pierce and Madison Counties (fig. 1), the Niobrara aquifer can yield water to domestic, stock, and municipal wells (Gutentag and others, 1984). There is little, if any, information available about recharge to the Niobrara aquifer; however, the average well depth for wells completed in the Niobrara aquifer is a little more than 100 feet (ft). Therefore, it has been inferred that the Niobrara aquifer is only used as a water source where the unit is unconfined and precipitation or surface water from a losing stream provide adequate recharge (Divine and Sibray, 2017). In northeastern Nebraska, recharge to the Niobrara aquifer is through glacial deposits or in bedrock outcrop areas (Engberg and Druliner, 1987).

The Pierre Shale is the regional confining unit for the western part of the study area separating secondary bedrock aquifers from overlying Pleistocene- or Quaternary-age deposits (fig. 2; Korus and Joeckel, 2011; Carney and others, 2015a, 2015b). The Pierre Shale is described as a shale with minor shaley chalk, siltstone, and sandstone intervals (table 1; Korus and Joeckel, 2011). Geologic units that are used as secondary bedrock aquifers east of the Pierre Shale subcrop area are not as extensively used to the west (fig. 2). In those areas, groundwater generally is too brackish for domestic purposes likely partly because the Pierre Shale restricts the recharge from precipitation (Engberg and Druliner, 1987).

The Ogallala Formation is the principal geologic unit in the High Plains aquifer system and is parts of the Lewis and Clark, Lower Elkhorn, and Lower Platte North NRDs (fig. 2). The Ogallala Formation consists of a poorly sorted mixture of sand, silt, clay, and gravel (Condra and Reed, 1943) and is generally unconsolidated or weakly consolidated but can contain layers of sandstone cemented by calcium carbonate or limestone. Within the study area, the Ogallala Formation has not been subdivided into stratigraphic units recognized in other areas because of the difficulty correlating these units in the subsurface with available test-hole data.

Paleovalleys are an important hydrogeologic feature that were formed by eastward draining Pleistocene-age streams that, prior to glaciation, incised valleys into exposed bedrock (Divine and others, 2009). With time, paleovalleys were gradually filled with often coarse sediments creating locally important aquifer systems. These sediments are capped by glacial till deposits and Pleistocene-age loess deposits (Korus and others, 2012; Cannia and others, 2017; Conservation and Survey Division, University of Nebraska-Lincoln, 2020a). The distribution and thickness of glacial outwash and till deposits are important in this study because overlying till deposits can form a confining cap to underlying Pleistocene-age sand and gravel deposits, preventing surface contamination into the aquifer and limiting groundwater/surface-water interaction (Cannia and others, 2017).

Alluvial aquifers located along major modern river and stream valleys are the primary water source for much of the study area (Divine and others, 2009; Korus and Joeckel, 2011). The highest density of high-capacity irrigation wells 
are located within the stream valleys of the Platte, Elkhorn, and Big Nemaha Rivers (fig. 1; Divine and others, 2009). The largest cities in the study area, Lincoln and Omaha, Nebr., receive much of their water from the Platte River alluvial aquifer (Divine and others, 2009). Another major alluvial aquifer system underlies the Todd Valley in Saunders County (fig. 2), this major alluvial aquifer system is hosted within deposits of a former channel of the Platte River that was abandoned during the late Pleistocene and filled with alluvial sediments (Divine, 2015).

\section{Previous Studies}

Previous studies have focused on describing the hydrogeologic characteristics of secondary bedrock aquifers and assessing groundwater quality within the study area (Engberg, 1984; Miller and Appel, 1997; Divine and Sibray, 2017). Divine and Sibray (2017) published a report describing the hydrogeology, water use, and water-quality characteristics of secondary bedrock aquifers in Nebraska, including the Western Interior Plains, Dakota, Codell, and Niobrara aquifers. Miller and Appel (1997) provided maps of aquifer characteristics and cross-sections of all major aquifer systems within Nebraska as well as maps of water type and total dissolved solid concentrations of the Dakota aquifer. Engberg (1984) analyzed water-quality data for aquifers completed in Cretaceous- and Paleozoic-age deposits within Nebraska and provided summary statistics and maps for major constituents.

For some studies, the geochemistry and water quality of secondary bedrock aquifers was not the primary focus, rather they were part of more comprehensive groundwater-quality assessments (Tanner and Steele, 1991; Verstraeten and Ellis, 1995; McGuire and others, 2012). Tanner and Steele (1991) collected groundwater samples from confined and unconfined Paleozoic aquifers as part of a groundwater-quality reconnaissance of the Nemaha NRD. Verstraeten and Ellis (1995) sampled 58 wells within the Papio-Missouri River NRD including 13 completed in the Dakota aquifer. McGuire and others (2012) sampled 133 wells completed in various aquifers from 1994 through 2009, including 38 wells completed in the Dakota aquifer, for major ions, trace elements, nutrients, stable isotopes, and selected age tracers. Groundwater sampled from the Dakota aquifer in the Papio-Missouri River NRD was characterized as being a calcium-sulfate water type that had recharged approximately 20 to 40 years ago (McGuire and others, 2012).

The groundwater chemistry of the Dakota aquifer has been the focus of several recent studies (Stotler, 2000; Gosselin and others, 2001; Harvey and others, 2007; Stotler and others, 2010). Gosselin and others (2001) analyzed the major ion concentrations from previously collected groundwater samples from 203 wells in eastern Nebraska (most of the wells were within the study area). Additional groundwater samples were collected to analyze strontium isotopic ratios and stable isotopic ratios of oxygen-18/oxygen-16 $\left(\delta^{18} \mathrm{O}\right)$ and hydrogen-2 (deuterium)/hydrogen-1 $\left(\delta^{2} \mathrm{H}\right)$. Using these datasets, three different water types were identified within the Dakota aquifer in eastern Nebraska. The first water type, which is characterized as Pleistocene-age recharge, is present within the Lewis and Clark NRD in Knox and Cedar Counties (fig. 1). Because the Dakota aquifer is confined and not easily recharged, the aquifer is vulnerable to overdevelopment and more active management may be necessary (Gosselin and others, 2001). The second water type is present in groundwater within Lancaster, Sarpy, and Saunders Counties (fig. 1) and is characterized as primarily local meteoric recharge (precipitation); in these areas, groundwater development would need to be balanced to ensure extraction does not exceed recharge (Gosselin and others, 2001). The final water type was identified as a mix of local meteoric precipitation and upwelling sodium chloride-type brines in Dakota and Thurston Counties (fig. 1). Gosselin and others (2001) noted that in Dakota and Thurston Counties it is important that groundwater extraction does not exceed local recharge to ensure that the freshwater/ saline-water interface does not migrate farther upward and adversely affect drinking-water quality (Gosselin and others, 2001).

Stotler and others (2010) examined the geochemical characteristics to determine the origin of groundwater in the Dakota aquifer in northern and northeastern Nebraska. Using selected major ions, age tracers, and stable isotopes, it was determined the source of water from sampled wells with a calcium-sulfate water type likely was the Madison aquifer (not shown in table 1) in the Black Hills in South Dakota (not shown on any maps). Groundwater sampled in wells in northwest Dixon County and areas to the west into Boyd County (not shown on any maps) was likely recharged in the Madison aquifer more than 25,000 years ago. Groundwater sampled in southeastern Dixon County and Dakota and Thurston Counties is likely the result of modern recharge (Stotler and others, 2010).

Harvey and others (2007) examined sources of groundwater discharge within eastern Nebraska's saline wetlands, which supports a unique ecosystem home to several threatened and endangered species. The saline wetlands are located along the northern edge of Lincoln, Nebr., and within the Salt Creek drainage in Lancaster and Saunders Counties (fig. 1) and are the result of saline groundwater discharge from the underlying Dakota aquifer and other Pennsylvanian-age units. The researchers determined that wetlands are sustained by groundwater flows along regional flow paths during the course of thousands to tens of thousands of years (Harvey and others, 2007). 


\section{Study Design and Methods}

This section describes the study design and methods used to collect groundwater-quality and age tracer samples and the analytical approaches used to describe and interpret these data. Groundwater levels were measured and groundwater samples were collected using the guidelines and protocols described in Cunningham and Schalk (2011) and in the USGS National Field Manual (U.S. Geological Survey, variously dated).

\section{Well Selection and Identification}

Well selection for this study was a collaborative process between the USGS, the coordinator of the ENWRA group, geologists from the University of Nebraska Conservation and Survey Division, and staff from the participating NRDs. Wells selected for sampling were chosen from the Nebraska Department of Natural Resources registered well database (Nebraska Department of Natural Resources, 2020). A detailed, reliable driller's log was required to ensure that the chosen well was screened within the targeted aquifer (Nebraska Department of Natural Resources, 2020). Monitoring wells were preferred over other well types because the depth and length of the screened interval is usually based on lithologic descriptions and geophysical logs collected by a professional geologist (Conservation and Survey Division, University of Nebraska-Lincoln, 2020a). In many instances, a monitoring well was not available and domestic or stock wells were chosen for sampling. Wells with relatively short screen intervals (10 ft or less) were preferred to ensure a representative sample from a specific interval within the aquifer. The type of well, aquifer sampled, and screen interval are listed in table 2. One well, LC-6S domestic, was not completed as a screened well, rather a casing was installed through $40 \mathrm{ft}$ of unconsolidated deposits until the borehole reached competent bedrock, then the borehole was left open to the formation from 40 to $95 \mathrm{ft}$ below land surface (table 2).

This report uses three different methods of well identification. The first method uses the USGS site number, which is a 15-digit number (table 2). The 15-digit USGS site number is particularly useful for accessing available water-quality or water-level data for a given well in the USGS National Water Information System (NWIS; U.S. Geological Survey, 2020b). The next identification method is the USGS station name. The station name uses the legal description of the well location and a local well name, which is the well name typically used by participating NRDs (hereinafter referred to as the well's "field name"), such as 19N 8E 20AD (LE-1). The last well identification method is the field name, such as LE-1 (table 2).

For this report, a total of 31 wells were sampled from the three secondary bedrock aquifers. Of these 31 wells, 22 wells were sampled from wells completed in the Dakota aquifer, 3 were sampled from wells completed in the Niobrara aquifer, and 6 were sampled from wells completed in Paleozoic aquifers (table 2, fig. 2). Well depths for sampled wells completed in the Dakota aquifer ranged from 95 to $750 \mathrm{ft}$ below land surface. Well depths for sampled wells completed in the Niobrara aquifer ranged from 120 to $180 \mathrm{ft}$ below land surface. Well depths for sampled wells completed in the Paleozoic aquifers ranged from 79 to $172 \mathrm{ft}$ below land surface (table 2). Of the 22 sampled wells completed in the Dakota aquifer, 15 were monitoring wells and 7 were domestic wells. Two monitoring wells and one domestic well were sampled for the Niobrara aquifer. One stock and five domestic wells were sampled for the Paleozoic aquifers (table 2).

\section{Sample Collection}

Groundwater samples were collected from August 9, 2016, to June 20, 2018 (table 2). Sample collection procedures followed the guidelines and protocols set forth in the USGS "National Field Manual for the Collection of Water-Quality Data" (U.S. Geological Survey, variously dated), the USGS Menlo Park Tritium Laboratory (U.S. Geological Survey, 2020c), and the USGS Reston Stable Isotopes Laboratory (U.S. Geological Survey, 2020d). The sampling protocols described in this section ensured that a representative sample of groundwater was collected at each well and that the samples were collected and handled in a way that minimized contamination.

Prior to sampling monitoring wells, the water level was measured to the nearest $0.01 \mathrm{ft}$ using a graduated electric tape following guidelines and protocols described in Cunningham and Schalk (2011). For domestic and stock wells, water level and well depth were not measured because the wells generally were in operation prior to sampling. Groundwater samples were collected from monitoring wells using a stainless-steel submersible pump. Groundwater samples from domestic or stock wells were collected at a hydrant or spigot closest to the well so that water was sampled prior to reaching a pressure tank or any other water treatment such as water softeners. Groundwater was sampled through Tygon tubing connected to the submersible groundwater pump or the chosen hydrant or spigot. Samples were collected in-line so that groundwater samples were not exposed to the atmosphere prior to collection.

Groundwater from all sampled wells was pumped into a flow-through chamber to facilitate the monitoring of the physical properties of the water to ensure that enough water was purged from the well casing prior to the collection of a representative sample. The physical properties - specific conductance, $\mathrm{pH}$, water temperature, and dissolved oxygen - were measured in the field at 3-minute intervals by a multiparameter sonde (YSI Incorporated, 2020). Representative samples were collected after three well volumes had been purged from the well and after sequential readings of the physical parameters stabilized within limits described by USGS "National Field Manual for the Collection of Water-Quality Data" (U.S. Geological Survey, variously dated). 
Table 2. Sampled well location, date sampled, completion information, and sampled aquifer, eastern Nebraska, $2016-18$.

[USGS, U.S. Geological Survey; Legal description as township number and direction, range number and direction, section number, and 2-4 quarters: N, north; W, west; E, east; ABCD, codes for the quarter section, as A, B, C, and D, respectively from largest to smallest quarter, where A is northeast, B is northwest, C is southwest, and D is southeast quarter of the next larger unit; D, domestic; M, monitoring; S, stock. Horizontal datum is referenced to the North American Datum of 1983]

\begin{tabular}{|c|c|c|c|c|c|c|c|c|c|c|}
\hline Site number & $\begin{array}{c}\text { USGS } \\
\text { station name }\end{array}$ & Field name & $\begin{array}{c}\text { Date } \\
\text { sampled }\end{array}$ & County & $\begin{array}{l}\text { Latitude, in } \\
\text { decimal } \\
\text { degrees }\end{array}$ & $\begin{array}{l}\text { Longitude, } \\
\text { in decimal } \\
\text { degrees }\end{array}$ & $\begin{array}{l}\text { Well } \\
\text { type }\end{array}$ & $\begin{array}{l}\text { Well depth, } \\
\text { in feet below } \\
\text { land surface }\end{array}$ & $\begin{array}{c}\text { Screen } \\
\text { interval, in } \\
\text { feet below } \\
\text { land surface }\end{array}$ & $\begin{array}{l}\text { Aquifer } \\
\text { sampled }\end{array}$ \\
\hline 413618096322901 & 19N 8E 20AD (LE-1) & LE-1 & $8 / 25 / 2016$ & Dodge & 41.62611111 & -96.553889 & $\mathrm{D}$ & 181 & $161-181$ & Dakota \\
\hline 413639096274901 & 19N 8E 24AA (LE-2) & LE-2 & $8 / 25 / 2016$ & Dodge & 41.60005556 & -96.450056 & M & 220 & $205-220$ & Dakota \\
\hline 413912096462201 & 19N 6E 6AA (LE-3) & LE-3 & $8 / 24 / 2016$ & Dodge & 41.65333333 & -96.772778 & $\mathrm{D}$ & 526 & $506-526$ & Dakota \\
\hline 413828096465801 & 19N 6E 6CD (LE-4) & LE-4 & $8 / 24 / 2016$ & Dodge & 41.65666667 & -96.7925 & $\mathrm{D}$ & 239 & $219-239$ & Dakota \\
\hline 424611097185201 & $\begin{array}{l}\text { 32N 1E 9BA } \\
\text { (LC-6S domestic) }\end{array}$ & LC-6S domestic & $8 / 11 / 2016$ & Cedar & 42.79388889 & -97.310556 & $\mathrm{D}$ & 95 & $40-95^{*}$ & Dakota \\
\hline 423317097160901 & 30N 1E 25BB (LC-4M) & LC $-4 \mathrm{M}$ & $8 / 10 / 2016$ & Cedar & 42.57027778 & -97.266889 & M & 730 & $712-730$ & Dakota \\
\hline 424713097170101 & $33 \mathrm{~N} 1 \mathrm{E} 35 \mathrm{CC}(\mathrm{LC}-6 \mathrm{M})$ & LC-6M & $8 / 9 / 2016$ & Cedar & 42.78338889 & -97.290556 & M & 520 & $500-520$ & Dakota \\
\hline 424713097170102 & $33 \mathrm{~N} 1 \mathrm{E} 35 \mathrm{CC}(\mathrm{LC}-6 \mathrm{D})$ & LC-6D & $8 / 9 / 2016$ & Cedar & 42.78777778 & -97.294167 & M & 750 & $730-750$ & Dakota \\
\hline 421730096390001 & 27N 7E 30AA (PM D-1) & PM D-1 & $8 / 11 / 2016$ & Dakota & 42.29916667 & -96.65 & $\mathrm{D}$ & 440 & $410-440$ & Dakota \\
\hline 410002096551101 & $12 \mathrm{~N} 4 \mathrm{E} 24 \mathrm{AB}$ (LPS-5) & LPS-5 & $10 / 27 / 2016$ & Seward & 41.00013889 & -96.916778 & $\mathrm{D}$ & 162 & $136-161$ & Dakota \\
\hline 411005096311701 & $14 \mathrm{~N} 8 \mathrm{E} 22 \mathrm{CB}(\mathrm{LPN}-1)$ & LPN-1 & $4 / 11 / 2017$ & Saunders & 41.19277778 & -96.5225 & M & 206 & $201-206$ & Dakota \\
\hline 410335096150101 & $\begin{array}{l}\text { 13N 10E 36BB } \\
\text { (D-SWSarpy1) }\end{array}$ & D-SWSarpy1 & $10 / 3 / 2016$ & Sarpy & 41.05022222 & -96.250167 & M & 117 & $107-117$ & Dakota \\
\hline 410613096071101 & 13N 11E 12DD (D-Sp1) & D-Sp1 & $9 / 28 / 2016$ & Sarpy & 41.10008333 & -96.116889 & M & 215 & $205-215$ & Dakota \\
\hline 410613096071102 & 13N 11E 12DD (D-Sp2) & $\mathrm{D}-\mathrm{Sp} 2$ & $9 / 28 / 2016$ & Sarpy & 41.10005556 & -96.116917 & M & 125 & $115-125$ & Dakota \\
\hline 411845096211203 & $\begin{array}{l}\text { 16N 9E 36NESE (Valley } \\
\text { City Park deep) }\end{array}$ & D-Va3 & $3 / 9 / 2018$ & Douglas & 41.3125 & -96.353333 & M & 204 & $194-204$ & Dakota \\
\hline 412758096222801 & 17N 9E 2DC (D-A1) & $\mathrm{D}-\mathrm{A} 1$ & $11 / 2 / 2016$ & Washington & 41.45016667 & -96.366889 & M & 297 & $287-297$ & Dakota \\
\hline 415958096152201 & $23 \mathrm{~N} 10 \mathrm{E} 2 \mathrm{DA}(\mathrm{D}-\mathrm{D} 1)$ & $\mathrm{D}-\mathrm{D} 1$ & $6 / 20 / 2018$ & Burt & 41.99944444 & -96.250194 & M & 180 & $170-180$ & Dakota \\
\hline 421406096294901 & $26 \mathrm{~N} 8 \mathrm{E} 11 \mathrm{CC}(\mathrm{D}-\mathrm{Th} 1)$ & D-Th1 & $10 / 14 / 2016$ & Thurston & 42.23355556 & -96.4835 & M & 370 & $360-370$ & Dakota \\
\hline 421406096294902 & $26 \mathrm{~N} 8 \mathrm{E} 11 \mathrm{CC}(\mathrm{D}-\mathrm{Th} 2)$ & D-Th2 & $10 / 14 / 2016$ & Thurston & 42.23341667 & -96.483583 & M & 275 & $265-275$ & Dakota \\
\hline 422616096343801 & $29 \mathrm{~N} 7 \mathrm{E} 35 \mathrm{DC}(\mathrm{D}-\mathrm{J} 1)$ & $\mathrm{D}-\mathrm{J} 1$ & $10 / 13 / 2016$ & Dakota & 42.43352778 & -96.566861 & M & 470 & $460-470$ & Dakota \\
\hline 422616096343802 & 29N 7E 35DC (D-J2) & D-J2 & $10 / 13 / 2016$ & Dakota & 42.4335 & -96.566833 & M & 280 & $270-280$ & Dakota \\
\hline 405921096535101 & 12N 5E 19DC (LPS-3) & LPS-3 & $11 / 10 / 2016$ & Lancaster & 40.98344444 & -96.883444 & $\mathrm{D}$ & 212 & $192-212$ & Dakota \\
\hline 423317097161001 & $30 \mathrm{~N} 1 \mathrm{E} 25 \mathrm{BB}(\mathrm{LC}-4 \mathrm{~S})$ & $\mathrm{LC}-4 \mathrm{~S}$ & $8 / 10 / 2016$ & Cedar & 42.55022222 & -97.273889 & M & 120 & $80-120$ & Niobrara \\
\hline 422344097120801 & $28 \mathrm{~N} 2 \mathrm{E} 16 \mathrm{DC}(\mathrm{LE}-5)$ & LE-5 & $8 / 23 / 2016$ & Cedar & 42.39555556 & -97.202222 & $\mathrm{D}$ & 157 & $137-157$ & Niobrara \\
\hline 422409097124601 & 28N 2E 16BC (LE-6) & LE-6 & $8 / 23 / 2016$ & Cedar & 42.4025 & -97.212778 & M & 180 & $170-180$ & Niobrara \\
\hline 405139096194801 & $10 \mathrm{~N} 10 \mathrm{E} 5 \mathrm{CB}$ (LPS-1) & LPS-1 & $10 / 6 / 2016$ & Cass & 40.86083333 & -96.33 & $\mathrm{D}$ & 116 & $104-114$ & Paleozoic \\
\hline
\end{tabular}


Table 2. Sampled well location, date sampled, completion information, and sampled aquifer, eastern Nebraska, 2016-18.-Continued

[USGS, U.S. Geological Survey; Legal description as township number and direction, range number and direction, section number, and 2-4 quarters: N, north; W, west; E, east; ABCD, codes for the quarter section, as A, B, C, and D, respectively from largest to smallest quarter, where A is northeast, B is northwest, C is southwest, and D is southeast quarter of the next larger unit; D, domestic; M, monitoring; S, stock. Horizontal datum is referenced to the North American Datum of 1983]

\begin{tabular}{|c|c|c|c|c|c|c|c|c|c|c|}
\hline Site number & $\begin{array}{c}\text { USGS } \\
\text { station name }^{1}\end{array}$ & Field name & $\begin{array}{c}\text { Date } \\
\text { sampled }\end{array}$ & County & $\begin{array}{l}\text { Latitude, } \\
\text { in decimal } \\
\text { degrees }\end{array}$ & $\begin{array}{c}\text { Longitude, } \\
\text { in decimal } \\
\text { degrees }\end{array}$ & $\begin{array}{l}\text { Well } \\
\text { type }\end{array}$ & $\begin{array}{l}\text { Well depth, } \\
\text { in feet below } \\
\text { land surface }\end{array}$ & $\begin{array}{c}\text { Screen } \\
\text { interval, in } \\
\text { feet below } \\
\text { land surface }\end{array}$ & $\begin{array}{l}\text { Aquifer } \\
\text { sampled }\end{array}$ \\
\hline 405213096205001 & 10N 10E 6BB (LPS-2) & LPS-2 & $10 / 6 / 2016$ & Cass & 40.87027778 & -96.347222 & $\mathrm{D}$ & 130 & $120-130$ & Paleozoic \\
\hline 402313095512401 & $5 \mathrm{~N} 14 \mathrm{E} 21 \mathrm{BC}(\mathrm{N}-3)$ & $\mathrm{N}-3$ & $10 / 5 / 2016$ & Nemaha & 40.41083333 & -95.866389 & $\mathrm{D}$ & 160 & $120-160$ & Paleozoic \\
\hline 401759096003301 & 4N 13E 19BC(N-5) & $\mathrm{N}-5$ & $11 / 8 / 2016$ & Nemaha & 40.29972222 & -96.009167 & $\mathrm{~S}$ & 172 & $152-172$ & Paleozoic \\
\hline 404950096205501 & 10N 10E 18CC (LPS-4) & LPS-4 & $10 / 5 / 2016$ & Cass & 40.81691667 & -96.333444 & $\mathrm{D}$ & 110 & $95-115$ & Paleozoic \\
\hline 401819095493701 & $4 \mathrm{~N} 14 \mathrm{E}$ 15DD (N-6) & $\mathrm{N}-6$ & $11 / 8 / 2016$ & Nemaha & 40.30016667 & -95.81675 & $\mathrm{D}$ & 79 & $69-79$ & Paleozoic \\
\hline
\end{tabular}

'The station name uses the legal description of the well location and a local well name (referred to as the well's "field name").

*Indicates well is not screened; instead is open to the formation at the interval given. 


\section{Sample Analysis and Reporting}

Water samples from all sites were analyzed for major ions, trace elements, nutrients including nitrate, and stable isotopes. Age tracers (tritium $\left[{ }^{3} \mathrm{H}\right]$ and carbon- $14\left[{ }^{14} \mathrm{C}\right]$ ) were analyzed for a subset of sampled wells. The constituent, analyzing laboratory, references to methods used, and field preservation procedures are given in table 3. Sampling results from all analyses are available online in the USGS NWIS (U.S. Geological Survey, 2020b). For the convenience of the reader, selected results are presented in this report to support the interpretations and conclusions.

For this report, conventional nomenclature was used to describe analyses of water samples for stable isotopes. The composition of stable isotopes of low-mass (light) of oxygen $(\mathrm{O})$ and hydrogen $(\mathrm{H})$ commonly are reported as " $\delta$ " (delta) values, which indicate parts per thousand or per mil. The reported value is compared to the isotopic ratio of the Vienna Standard Mean Ocean Water (Clark and Fritz, 1997). The general expression for the $\delta$ value is calculated by the following equation (Clark and Fritz, 1997):

$$
\delta\left(\text { in per mil) }=\left[\frac{R x}{R s}-1\right] * 1,000\right.
$$

where

$$
\begin{aligned}
& R x \quad \text { is the ratio of the heavy to light isotope of the } \\
& \text { sample; and } \\
& R s \quad \text { is the ratio of the heavy to light isotope of } \\
& \text { the standard (Vienna Standard Mean } \\
& \text { Ocean Water). }
\end{aligned}
$$

A negative $\delta$ value indicates that the sample is depleted of the rare isotope relative to the standard; that is, the sample is isotopically "light." A positive $\delta$ value indicates that the sample is enriched in the rare isotope relative to the standard; that is, the sample is isotopically "heavy."

Understanding and interpreting the stable isotopic composition of groundwater samples is aided by understanding hydrologic processes that can affect isotopic ratios. Isotopic fractionation occurs where the isotopic composition is altered by chemical, biological, or physical processes that may result in the preferential enrichment or depletion of one isotope over another. This fractionation process partitions isotopes as a function of the differences in the masses of the isotopes. Because the heavier isotope has a stronger molecular bond (oxygen- $18\left[{ }^{18} \mathrm{O}\right]$ has a stronger molecular bond than oxygen-16 $\left[{ }^{16} \mathrm{O}\right]$ and deuterium $\left[{ }^{2} \mathrm{H}\right]$ has a stronger molecular bond than hydrogen-1 $\left[{ }^{1} \mathrm{H}\right]$ ), the liquid phase of water generally is isotopically "heavier" than the gaseous phase (Kendall and Caldwell, 1998). As a result, evaporation is a major fractionation process in which the lighter isotope is concentrated in water vapor, whereas the heavier isotope enriches the aqueous phase. Additional information on isotopes and their presence in the environment can be found in references such as Clark and Fritz (1997).

\section{Data-Analysis Procedures}

Data-analysis procedures included general statistical analyses, creation of Piper diagrams (Piper and Garrett, 1953), scatter plots, and summary tables. This report only contains selected plots and tables necessary to support the interpretations and conclusions presented herein. Analyses of stable isotope data and age tracer results, including radiocarbon dating procedures, are also described in this section of the report.

Statistical analyses were completed to determine if differences in the concentrations of selected constituent were significant between aquifers. Two nonparametric tests were performed for this report: Kruskal-Wallis and Wilcoxon Rank Sum (Helsel and others, 2020). The Kruskal-Wallis test was used to determine differences between distribution of concentrations of selected constituents in samples by aquifer. For this report, this test was performed on samples from wells screened in the Dakota, Niobrara, or Paleozoic aquifers. The null hypothesis for the test was that the distributions for the groups are identical, and the alternative hypothesis was that at least one of the group medians is different from the others (Helsel and others, 2020). The Wilcoxon Rank Sum test (Helsel and others, 2020) was used to determine if differences between distributions of the two subsets of samples collected from the Dakota aquifer were significant. Water samples collected from the Dakota aquifer were divided into two groups based on the dominant water type, which is discussed in further detail in the "Major Ions and Trace Elements" subsection later in this report. The null hypothesis for the test was that the distributions for the groups are identical, and the alternative hypothesis was that at least one of the distributions is different from the others (Helsel and others, 2020). For both types of nonparametric statistical tests, the null hypothesis was rejected when the calculated $p$-value was less than an alpha value $(\alpha)$ of 0.05 , which indicates a 95-percent confidence level that the probability value from the statistical test generated an accurate representation of the populations being tested (Helsel and others, 2020). A $p$-value is defined as the measure of the probability that an observed difference occurred by random chance (Helsel and others, 2020). If a calculated $p$-value is less than 0.05 , then it can be inferred there is a significant difference between the medians of the sample groups with 95-percent confidence.

Nonparametric statistical methods rely on the conversion of data to ranked values and do not require that the data be distributed normally (Helsel and others, 2020). Censored data, which have values less than the reporting limit of the analytical procedure, were kept for analyses. In this report, for the nonparametric statistical analyses, each censored value was assigned a value equal to one-half the reporting limit. A value of one-half the reporting limit ensures that the censored data are smaller than the smallest number above the reporting limit. Because the tests performed are nonparametric and compare independent populations by ranking the data, assigning a minimum value to the censored data does not affect the hypothesistest results (Helsel and others, 2020). 
Table 3. Laboratory analytical methods and field preservation procedures for water-quality constituents.

[USGS, U.S. Geological Survey; $\mu$ m, micrometer; NWQL, National Water Quality Laboratory (Denver, Colorado); ${ }^{\circ}$ C, degree Celsius; <, less than; HNO 3 ; nitric acid; RSIL, Reston Stable Isotope Laboratory (Reston, Virginia); MPTL, Menlo Park Tritium Laboratory (Menlo Park, California); WHOI, Woods Hole Oceanographic Institution (Woods Hole, Massachusetts)]

\begin{tabular}{|c|c|c|c|c|c|}
\hline Analyte(s) & $\begin{array}{l}\text { Analyzing } \\
\text { laboratory }\end{array}$ & Analytical method & Reference & Field preservation procedure & $\begin{array}{l}\text { Number of } \\
\text { samples } \\
\text { collected }\end{array}$ \\
\hline Physical properties & Analyzed onsite & Various methods & USGS (variously dated) & None & 31 \\
\hline Carbonate alkalinity & Analyzed onsite & Inflection point titration & USGS (variously dated) & Filter through 0.45 - $\mu \mathrm{m}$ filter & 31 \\
\hline Nutrients & USGS NWQL & Various methods & Fishman (1993) & $\begin{array}{l}\text { Filter through } 0.45-\mu \mathrm{m} \text { filter, chill, and } \\
\quad \text { maintain at } 4{ }^{\circ} \mathrm{C}\end{array}$ & 31 \\
\hline Major ions & USGS NWQL & Inductively coupled plasma & Fishman and Friedman (1989); Fishman (1993) & $\begin{array}{l}\text { Anions: filter through } 0.45-\mu \mathrm{m} \text { filter, } \\
\text { Cations: filter through } 0.45 \text { - } \mu \mathrm{m} \text { filter, } \\
\text { acidify sample to } \mathrm{pH}<2 \text { with nitric } \\
\text { acid }\left(\mathrm{HNO}_{3}\right)\end{array}$ & 31 \\
\hline Trace elements & USGS NWQL & $\begin{array}{l}\text { Inductively coupled plasma, } \\
\text { atomic absorption } \\
\text { spectrometry }\end{array}$ & $\begin{array}{l}\text { Fishman and Friedman (1989); Fishman (1993); } \\
\text { Garbarino (1999); Struzeski and others (1996); } \\
\text { Garbarino and Damrau (2001); Garbarino and } \\
\text { others (2006) }\end{array}$ & $\begin{array}{l}\text { Filter through } 0.45-\mu \mathrm{m} \text { filter, acidify } \\
\text { sample to } \mathrm{pH}<2 \text { with nitric acid } \\
\left(\mathrm{HNO}_{3}\right)\end{array}$ & 31 \\
\hline Stable isotopes & USGS RSIL & Mass spectrometry & USGS (2020d) & Fill bottle two-thirds full & 21 \\
\hline Tritium & USGS MPTL & $\begin{array}{l}\text { Electrolytic enrichment and } \\
\text { liquid scintillation }\end{array}$ & USGS (2020c) & $\begin{array}{l}\text { Fill bottle to top, seal with cap and wrap } \\
\text { with electrical tape }\end{array}$ & 13 \\
\hline Carbon-14 & WHOI & $\begin{array}{l}\text { Accelerator mass } \\
\text { spectrometry }\end{array}$ & WHOI (2020) & $\begin{array}{l}\text { Filter through } 0.45-\mu \mathrm{m} \text { filter, bottom fill } \\
\text { bottle flushing two volumes before } \\
\text { capping and sealing with electrical } \\
\text { tape, chill and maintain at } 4{ }^{\circ} \mathrm{C}\end{array}$ & 25 \\
\hline
\end{tabular}




\section{Stable Isotopes}

In terrestrial waters, the ratio of the two most common isotopes of $\mathrm{O}$ and $\mathrm{H}\left(\delta^{18} \mathrm{O}\right.$ and $\left.\delta^{2} \mathrm{H}\right)$ are covariant and vary by a factor of 5 and 2 percent, respectively (Coplen and Kendall, 2000). Craig (1961) determined that for fresh water, isotopic composition of precipitation worldwide could be correlated on a global scale and could be described using the global meteoric water line, which is given as $\delta^{2} \mathrm{H}=8 \delta^{18} \mathrm{O}+10$. The global meteoric water line is the average of many local or regional meteoric water lines that differ in slope and $\delta^{2} \mathrm{H}$ intercept (Clark and Fritz, 1997). Variations in the slope and $\delta^{2} \mathrm{H}$ intercept for local and regional meteoric water lines are affected by many factors such as season and climate. For a given area, precipitation during cold seasons is depleted in ${ }^{2} \mathrm{H}$ and ${ }^{18} \mathrm{O}$, whereas precipitation in warm seasons is typically isotopically enriched. Precipitation falling in cold regions and climates is isotopically depleted and precipitation falling in with warmer regions and climates is isotopically enriched (Clark and Fritz, 1997).

This report uses a local meteoric water line (LMWL) established by Harvey (2001) from analysis of precipitation samples collected at Mead, Nebr. (fig. 1). Harvey (2001) reported the LMWL as $\delta^{2} \mathrm{H}=7.40 \delta^{18} \mathrm{O}+7.32$. Although Mead (fig. 1) is approximately at the center of the study area, it is more than 100 miles from the northern most sample and approximately 70 miles from the southernmost sample, so it is assumed that the LMWL at Mead, Nebr., adequately represents the study area used in this report.

\section{Age Tracers}

Estimating the age of groundwater is an increasingly common approach to inform water-resource-management strategies. Groundwater age is often used to estimate groundwater recharge rates, examine the sustainability of groundwater resources, and assist in groundwater model calibration (Kazemi and others, 2006). Groundwater age can also complement studies focused on groundwater quality. Aquifers containing primarily recently recharged groundwater are vulnerable to contamination from anthropogenic sources. Conversely, if an aquifer contains waters that are determined to be premodern (recharged prior to 1950), naturally occurring contaminants such as arsenic can be elevated because longer residence times in the aquifer can result in higher concentrations of dissolved constituents in groundwater (Lindsey and others, 2019). For this study, ${ }^{3} \mathrm{H}$ and ${ }^{14} \mathrm{C}$ samples were collected from selected wells. Data-analysis procedures, including the ${ }^{3} \mathrm{H}$ classification approach and radiocarbon adjustments of ${ }^{14} \mathrm{C}$ data, are discussed in the following subsections.

\section{Tritium}

${ }^{3} \mathrm{H}$ is a naturally occurring radioactive isotope of hydrogen with a half-life of 4,500 days (12.3 years; Kazemi and others, 2006) and is directly related to the time since substantial thermonuclear testing in the 1950s and 1960s. The use of ${ }^{3} \mathrm{H}$ in groundwater age studies is well established and valuable because isotope concentrations of the hydrogen atoms in the water molecule are measured rather than concentrations of a dissolved constituent; however, because of the time that has lapsed since substantial thermonuclear testing, this age tracer may not be as useful as other tracers (Kazemi and others, 2006). ${ }^{3} \mathrm{H}$ was present in the atmosphere prior to thermonuclear testing in the 1950s and 1960s as a result of natural production in the upper atmosphere through the bombardment of nitrogen by neutrons in cosmic radiation (Solomon and Cook, 2000). The natural background activity of ${ }^{3} \mathrm{H}$ in precipitation prior to 1952 ranges from about 1 to 10 tritium units with each unit equal to one ${ }^{3} \mathrm{H}$ atom in 1,018 atoms of hydrogen (Kazemi and others, 2006). Beginning in 1952, large amounts of ${ }^{3} \mathrm{H}$ were added to the atmosphere from aboveground testing of thermonuclear devices, and ${ }^{3} \mathrm{H}$ combined with $\mathrm{O}$ to form tritiated water, which dispersed throughout the hydrosphere. After the onset of thermonuclear testing, large increases of ${ }^{3} \mathrm{H}$ concentrations in precipitation were noticed and continued to rise until an international treaty banned atmospheric thermonuclear testing in 1963 (Solomon and Cook, 2000). The concentration of ${ }^{3} \mathrm{H}$ in precipitation remained high for decades, but recently (since 2010) concentrations have leveled off, indicating a return to near prebomb (prior to 1953) concentrations (Lindsey and others, 2019).

Sampled wells were classified based on the concentration of ${ }^{3} \mathrm{H}$ in groundwater using an approach described in Lindsey and others (2019). The classification is based on a general understanding of how ${ }^{3} \mathrm{H}$ concentrations change in groundwater in response to changes in ${ }^{3} \mathrm{H}$ concentrations in precipitation. The three ${ }^{3} \mathrm{H}$ concentration classifications are modern (recharged in 1953 or later), premodern (recharged prior to 1953), and mixed (a mixture of waters recharge prior to 1953 and after 1953). Concentrations of ${ }^{3} \mathrm{H}$ in groundwater that has recharged before 1953 would have a much lower concentration than the measured background concentration because of radioactive decay during the time that elapsed between recharge and sampling. A threshold was calculated by correcting the $1953{ }^{3} \mathrm{H}$ background concentration (the most recent concentrations prior to thermonuclear testing) reported in Michel and others (2018) for radioactive decay (Lindsey and others, 2019). If the ${ }^{3} \mathrm{H}$ concentration of the groundwater sample is less than the calculated threshold, it can be inferred that the water was recharged prior to 1953 . In addition, ${ }^{3} \mathrm{H}$ concentrations from a groundwater sample that are greater than any of the postbomb (after 1963) peak concentrations in precipitation that have been reduced by the radioactive decay that would have occurred from the precipitation date to the date of sampling must have recharged in 1953 or later and are classified as modern. If a sample concentration is between these upper and lower bounds, then a sample is classified as a mixture of premodern and modern waters (Lindsey and others, 2019). 
The calculated thresholds for premodern and modern vary slightly across the study area because of differences in ${ }^{3} \mathrm{H}$ concentration in precipitation. Michel and others (2018) estimated ${ }^{3} \mathrm{H}$ concentrations in precipitation for the conterminous United States in quadrangles for every 2 degrees in latitude and every 5 degrees in longitude. The premodern and modern thresholds for samples collected in wells in the northern part of the study area were slightly higher than samples in the southern part of the study area.

\section{Carbon-14}

Measurements of ${ }^{14} \mathrm{C}$ concentrations in groundwater are often used for dating premodern waters with long residence times. Age dating with ${ }^{14} \mathrm{C}$ techniques uses the dissolved organic or inorganic carbon in water and not the water molecule itself (Clark and Fritz, 1997). Wang and others (1998) reported the natural production of ${ }^{14} \mathrm{C}$ in the atmosphere by the interaction of cosmic-ray-produced neutrons with nitrogen (Kalin, 2000). Once produced, ${ }^{14} \mathrm{C}$ becomes incorporated into carbon dioxide and assimilates into the hydrosphere. The halflife of ${ }^{14} \mathrm{C}(5,730$ years $)$ and the ubiquity of carbon make it an ideal tracer to date groundwater that can be thousands to tens of thousands of years old (Kalin, 2000).

Analyses of ${ }^{14} \mathrm{C}$ are typically reported as percent Modern Carbon (often referred to as pMC). Prior to the thermonuclear testing in the 1950s and 1960s, atmospheric composition of ${ }^{14} \mathrm{C}$ was relatively constant $\left(A_{0}\right.$ in eq. 2$)$ and is designated as 100 pMC (Parkhurst and Plummer, 1993). Apparent groundwater age can be determined by examining the ${ }^{14} \mathrm{C}$ in dissolved inorganic carbon within a groundwater sample. If the concentration of ${ }^{14} \mathrm{C}$ in the atmosphere is known at the time of recharge, then the age of groundwater sample can be estimated. The age of the water was determined by the following equation (modified from Parkhurst and Plummer, 1993):

$$
t=\frac{5,730}{\ln (2)} \ln \left(\frac{A o}{A}\right)
$$

where

$$
\begin{gathered}
t \quad \begin{array}{l}
\text { is the estimated age of the groundwater, } \\
\text { in years; }
\end{array} \\
\text { is the half-life of }{ }^{14} \mathrm{C} \text {, in years; } \\
\text { is the starting concentration of }{ }^{14} \mathrm{C} \text { in the } \\
\text { water, in percent Modern Carbon; and } \\
\text { is the concentration of }{ }^{14} \mathrm{C} \text { in the sample, in } \\
\text { percent Modern Carbon. }
\end{gathered}
$$

The initial concentration of ${ }^{14} \mathrm{C}$ in precipitation $\left(\mathrm{A}_{0}\right)$ is modified through several processes that need to be accounted for to provide meaningful estimates of apparent groundwater age. NetPathXL (Parkhurst and Charlton, 2008) was used to account for geochemical processes such as isotopic exchange in the unsaturated zone. NetPathXL provides several radiocarbon adjustment models to estimate the initial concentration of ${ }^{14} \mathrm{C}$. For this report, the initial concentrations of ${ }^{14} \mathrm{C}$ in precipitation were estimated using the revised Fontes and
Garnier (1979) radiocarbon adjustment model (Han and Plummer, 2013) within NetPathXL (Parkhurst and Charlton, 2008). It was assumed that there was carbon isotopic exchange with solid carbonate mineral within the saturated zone. Ages derived from ${ }^{14} \mathrm{C}$ age-dating analyses generally are on the order of hundreds to tens of thousands of years and results are reported in years before present. Radiocarbon adjustments are complicated, and many details are not described in this report. However, details on the use and limitations of ${ }^{14} \mathrm{C}$ in dating of groundwater can be found elsewhere, such as Clark and Fritz (1997) and Kazemi and others (2006).

\section{Quality Assurance and Quality Control}

Quality control samples were collected for this study and included field blanks and field replicates. Quality control samples were collected to evaluate and determine if samples had been contaminated or if the data were biased by the collection, processing, storage, or analysis of the samples. For this study, six field blanks and five field replicate samples were collected. Selected statistics for the field blank results and the relative percent difference between replicate samples are shown in table 4 . The relative percent difference is calculated using equation 3 given below.

$$
R P D=\frac{S_{1}-S_{2}}{\left(\frac{S_{1}+S_{2}}{2}\right)} \times 100
$$

where

$$
\begin{aligned}
& S_{1} \quad \text { is the concentration of field replicate } \\
& \text { sample 1; } \\
& S_{2} \quad \text { is the concentration of field replicate } \\
& \text { sample 2; and } \\
& R P D \quad \text { is the relative percent difference between field } \\
& \text { replicate samples } 1 \text { and } 2 \text {. }
\end{aligned}
$$

Field blanks are collected to determine the occurrence and magnitude of sample contamination from collection, processing, storage, and analysis. Field blanks are collected using water that has been certified to be free of inorganic constituents and were analyzed for major ions, trace elements, and nutrients. Generally speaking, few detections, or "hits," were analyzed from the field blanks (table 4). Most detections were within an order of magnitude of the lower detection limit for the specific constituent; however, two blank samples, DSWSarpy 1 and LC $-4 \mathrm{~S}$, had concentrations of cobalt and zinc, respectively, that exceed an order of magnitude of the detection limit. Concentrations of copper were detected in blank samples that exceeded an order of magnitude of the detection limit for wells D-SWSarpy1 and D-Sp2 (table 4).

Five field replicate samples were collected to assess the variability in analytical results. The relative percent difference in the concentrations of the replicate samples for major ions all were 5 percent or less of each other, with the exception of the concentration of magnesium, sodium, and fluoride in one 
Table 4. Selected statistics of field blank samples and relative percent difference between replicate samples, eastern Nebraska, 2016-18.

$\left[\mathrm{mg} / \mathrm{L}\right.$, milligram per liter; --, not applicable or not sampled; <, less than; $\mathrm{NH}_{3}$, ammonia; $\mathrm{NH}_{4}{ }^{+}$, ammonium; $\mathrm{N}$, nitrogen; $\mu \mathrm{g} / \mathrm{L}$, microgram per liter; ${ }^{14} \mathrm{C}$, carbon-14; \%, percent; $\mathrm{pCi} / \mathrm{L}$, picocurie per liter; $\delta^{13} \mathrm{C}$, carbon isotope ratio in per mil Vienna Peedee belemnite; $\delta^{2} \mathrm{H}$, hydrogen isotope ratio in per mil Vienna Standard Mean Ocean Water; $\delta^{18} \mathrm{O}$, oxygen isotope ratio in per mil Vienna Standard Mean Ocean Water]

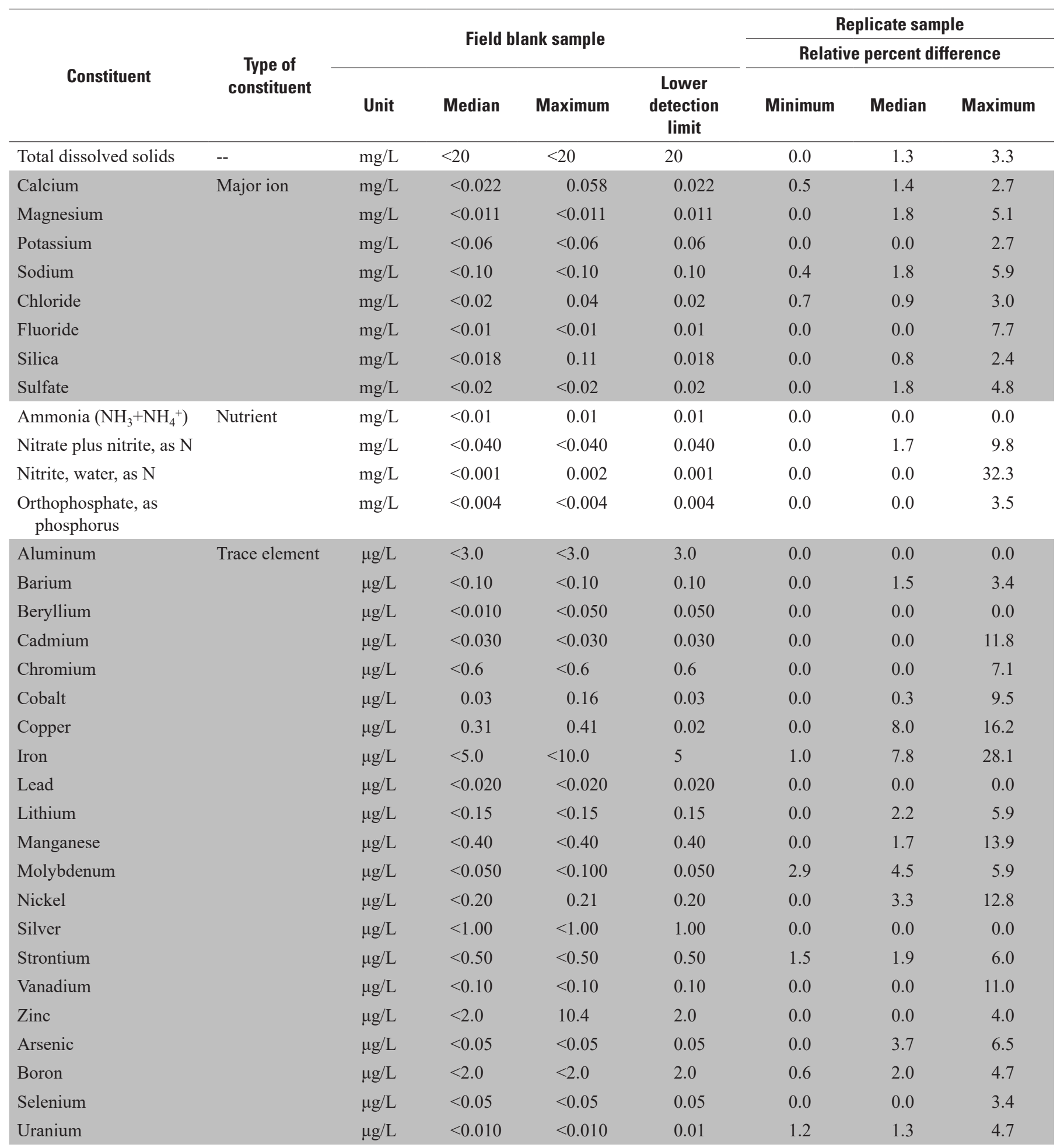


Table 4. Selected statistics of field blank samples and relative percent difference between replicate samples, eastern Nebraska, 2016-18.-Continued

$\left[\mathrm{mg} / \mathrm{L}\right.$, milligram per liter; --, not applicable or not sampled; <, less than; $\mathrm{NH}_{3}$, ammonia; $\mathrm{NH}_{4}^{+}$, ammonium; $\mathrm{N}$, nitrogen; $\mu \mathrm{g} / \mathrm{L}$, microgram per liter; ${ }^{14} \mathrm{C}$, carbon-14; \%, percent; $\mathrm{pCi} / \mathrm{L}$, picocurie per liter; $\delta^{13} \mathrm{C}$, carbon isotope ratio in per mil Vienna Peedee belemnite; $\delta^{2} \mathrm{H}$, hydrogen isotope ratio in per mil Vienna Standard Mean Ocean Water; $\delta^{18} \mathrm{O}$, oxygen isotope ratio in per mil Vienna Standard Mean Ocean Water]

\begin{tabular}{|c|c|c|c|c|c|c|c|c|}
\hline \multirow[b]{3}{*}{ Constituent } & \multirow{3}{*}{$\begin{array}{c}\text { Type of } \\
\text { constituent }\end{array}$} & \multirow{2}{*}{\multicolumn{4}{|c|}{ Field blank sample }} & \multirow{2}{*}{\multicolumn{3}{|c|}{$\begin{array}{c}\text { Replicate sample } \\
\text { Relative percent difference }\end{array}$}} \\
\hline & & & & & & & & \\
\hline & & Unit & Median & Maximum & $\begin{array}{c}\text { Lower } \\
\text { detection } \\
\text { limit }\end{array}$ & Minimum & Median & Maximum \\
\hline${ }^{14} \mathrm{C}$ & Isotope & $\%$ modern & -- & -- & -- & 0.1 & 1.2 & 1.5 \\
\hline Tritium & & $\mathrm{pCi} / \mathrm{L}$ & -- & -- & -- & 0.1 & 12.1 & 24.0 \\
\hline$\delta^{2} \mathrm{H}$ & & per mil & -- & -- & -- & 0.4 & 0.7 & 1.7 \\
\hline$\delta^{18} \mathrm{O}$ & & per mil & -- & -- & -- & 0.4 & 0.5 & 1.9 \\
\hline
\end{tabular}

set of replicate samples, which were 5.1, 5.9, and 7.7 percent, respectively (table 4 ). It should be noted that when concentrations for replicate samples are low, small differences in concentration can result in higher relative percent differences. For nutrients, the relative percent differences in the concentrations of the replicate samples for most nutrients were less than 5 percent or within an order of magnitude of the detection limit. Notable exceptions included the concentration of nitrate plus nitrite in one set of replicate samples that had a 9.8-percent (0.39 milligram per liter [mg/L]) difference and nitrite in one set of samples which had a 32.3-percent $(0.005 \mathrm{mg} / \mathrm{L})$ difference (table 4$)$. For trace elements, the six trace elements with the greatest maximum relative percent differences were copper (16.2 percent), iron (28.1 percent), cadmium (11.8 percent), manganese (13.9 percent), nickel (12.8 percent), and vanadium (11.0 percent); however, the associated differences in concentration were within one order of magnitude of the lower detection limit (table 4). It is important to note that because the concentrations of these constituents are low, the calculated relative percent difference values can be anomalously high. For the trace element cobalt, the maximum relative percent difference was calculated at 9.5 percent, which was an order of magnitude greater than the detection limit. Exceeding the order of magnitude threshold indicates the possibility that some samples may have a positive bias. The median relative percent difference for all replicate samples was 0.3 percent. The median relative percent difference for iron was 7.8 percent but the difference in concentrations was within an order of magnitude of the lower detection limit (table 4). Replicates were only collected for two ${ }^{3} \mathrm{H}$ samples (D-A1 and D-SWSarpy1). The relative percent difference was not calculated for D-A1 because the ${ }^{3} \mathrm{H}$ concentrations were below the detection limit. The relative percent difference calculated for ${ }^{3} \mathrm{H}$ in the sample from well D-SWSarpy1 was 24, which was due to the fact that ${ }^{3} \mathrm{H}$ concentrations were fairly low and differences between samples are close to the lower detection limit.

\section{Quality and Age of Groundwater}

This section of the report describes the water quality, geochemical characteristics, and groundwater age of the samples collected from wells screened in the Dakota aquifer, Niobrara aquifer, and the Paleozoic aquifers. Presented in this section are descriptions of the groundwater sampling results, statistical analyses, stable isotope and age tracer interpretations, and a discussion of groundwater management implications. Much of the groundwater sampling results are summarized in a series of maps, graphs, and tables. Results from groundwater sampling not presented in this report are provided in the USGS NWIS database (U.S. Geological Survey, 2020b).

\section{Major lons and Trace Elements}

Major ion concentrations for each sample are plotted as a Piper diagram (Piper and Garrett, 1953) shown in figure 3. Analysis of the major ion concentrations indicates samples collected from the Dakota aquifer show no single primary water type; however, the two most common water types within the Dakota aquifer are calcium bicarbonate (10 samples) and calcium sulfate ( 7 samples; figs. 3 and 4, table 5). Samples that were characterized as calcium bicarbonate generally had lower specific conductance and concentrations of total dissolved solids (table 5A). This is consistent with previous studies, which determined that calcium bicarbonate was the dominant water type where the Dakota aquifer was unconfined and groundwater was recharged from local precipitation (Gosselin and others, 2001). Sampled wells that are not characterized as calcium bicarbonate water type typically had higher concentrations of total dissolved solids and lower dissolved oxygen concentrations (table $5 A$ ). Calcium sulfate water types often are present where Cretaceous-age shales overly the Dakota aquifer, such as in Cedar County in the northern part of the study area (fig. 4). In Dakota County, wells D-J1 and D-J2 are characterized as 


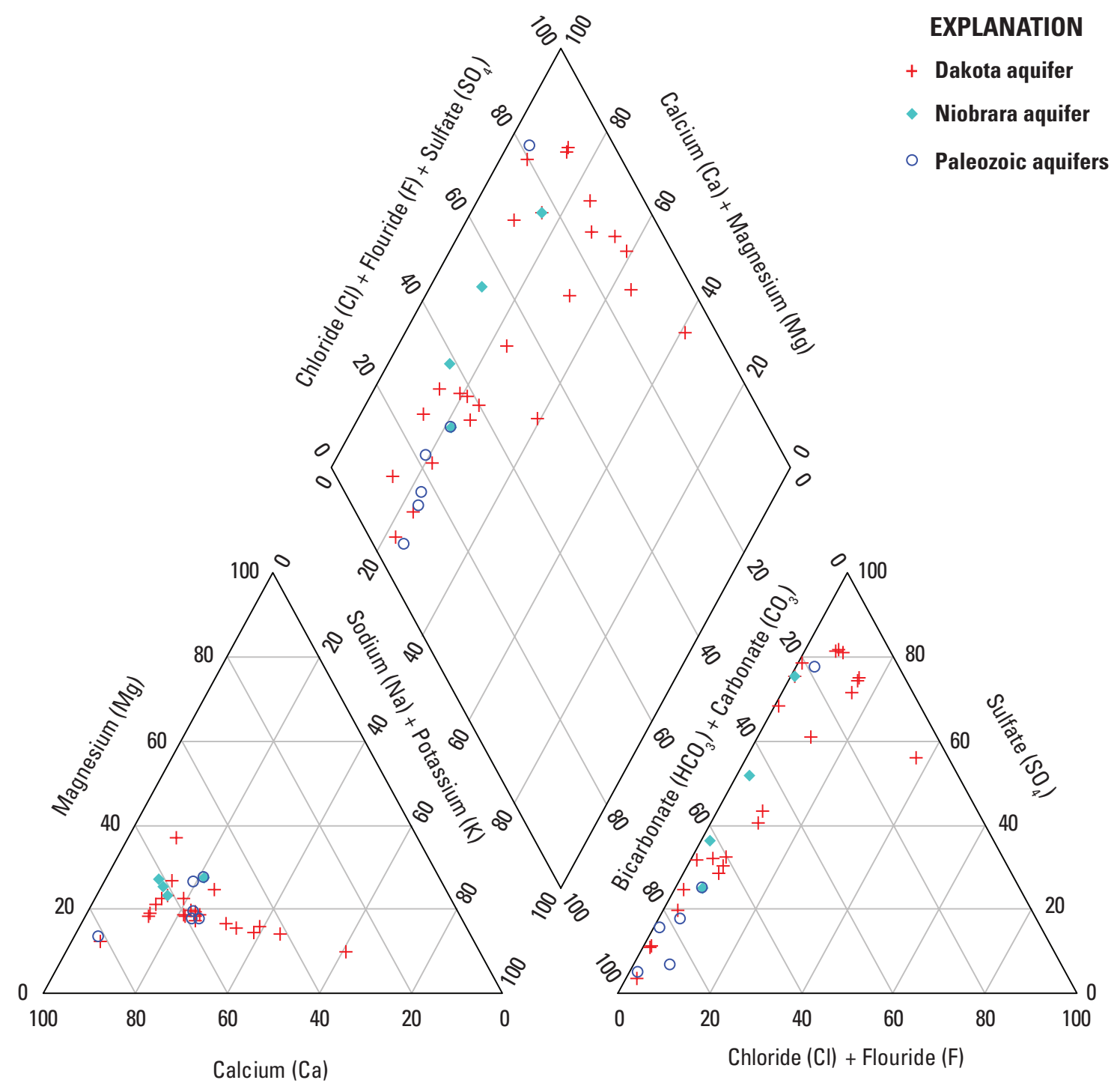

Percentage of total millequivalents per liter

Figure 3. Ionic composition of groundwater from Dakota aquifer, Niobrara aquifer, and Paleozoic aquifers, eastern Nebraska, 2016-18. 


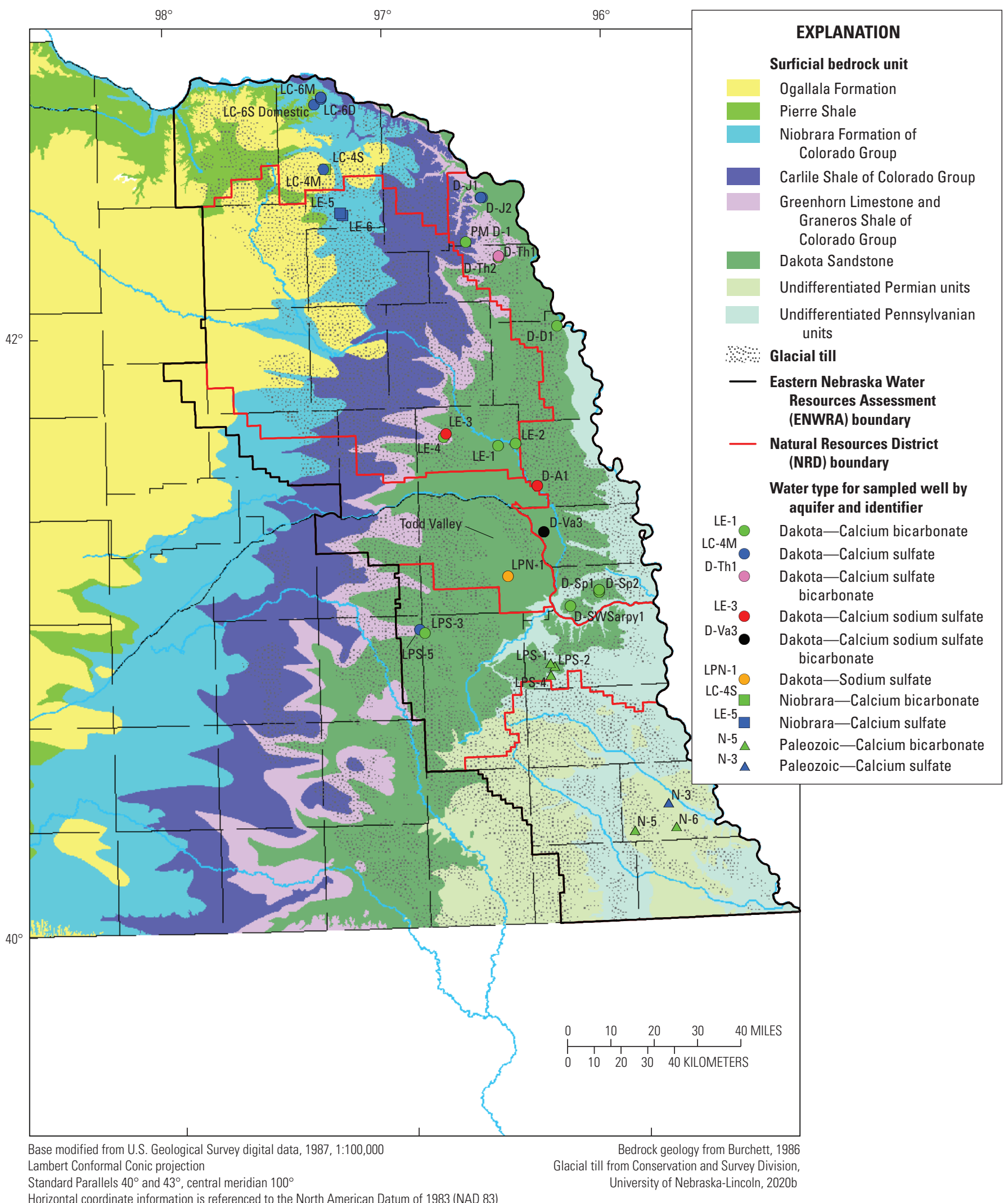

Figure 4. Dominant water type for wells completed in the Dakota aquifer, Niobrara aquifer, and Paleozoic aquifers, eastern Nebraska, 2016-18. 
calcium sulfate waters (fig. 4). Both wells are screened beneath sequences of clay, claystone, siltstone, and sand deposits, indicating the Dakota aquifer is at least partially confined in this location and meteoric recharge would be limited.

Sodium was the dominant cation for one sample (LPN-1; fig. 4, table $5 A$ ) and a subdominant cation for three samples (LE-3, D-Va3, and D-A1), all from the Dakota aquifer. With the exception of D-Va3, these sodium dominant and subdominant samples display higher specific conductance and concentrations of the total dissolved solids concentration compared to most samples collected in the study area (table $5 A$ ). The Dakota aquifer in these locations is confined by interbedded mudstone or shales within the Dakota or by overlying Late Cretaceous-age shales (Conservation and Survey Division, University of Nebraska-Lincoln, 2020a; Katie Cameron, Eastern Nebraska Water Resources Assessment, written commun., 2019), which can limited meteoric recharge (fig. 4).

In some locations, the dominant water type of the Dakota aquifer varied by depth. Domestic wells LE- 4 and LE-3 are located in northwest Dodge County (fig. 1) and are approximately 1 mile apart. Well LE- 4 is $239 \mathrm{ft}$ deep and screened in the upper part of the Dakota aquifer, and well LE-3 is $526 \mathrm{ft}$ and is completed in the lower part of the Dakota aquifer. Sampling data indicate that groundwater sampled from well LE -4 is calcium bicarbonate water type and likely recharged by meteoric water (fig. 4). Well LE-3 is a calcium sodium sulfate water type and underlies interbedded shale units within the Dakota aquifer (Conservation and Survey Division, University of Nebraska-Lincoln, 2020a; Katie Cameron, Eastern Nebraska Water Resources Assessment, written commun., 2019) where meteoric recharge is likely limited. The total dissolved solids concentration of well LE-3 was more than four times greater than that of well LE-4 (table $5 A$ ).

Samples collected from wells completed in the Niobrara aquifer and Paleozoic aquifers were characterized as either calcium bicarbonate or calcium sulfate water types (figs. 3 and 4 , table $5 A$ ). Of the three samples collected from the Niobrara aquifer, one sample (LC-4S) was characterized as calcium bicarbonate and two samples (LE-5 and LE-6) were characterized as calcium sulfate. The sample characterized as calcium bicarbonate water type (LC-4S) had the lowest concentration of total dissolved solids compared to the other two samples (table $5 A$ ). The sample collected at well LE-5 indicated higher concentration of total dissolved solids and lower concentrations of dissolved oxygen when compared to well LE-6. Well LE-5 had a well depth of $157 \mathrm{ft}$ and was screened below a thick sequence of clay; this clay layer may be restricting meteoric recharge to the aquifer at this location. A clay layer was not encountered when drilling well LE-6, which has a well depth of $180 \mathrm{ft}$ and is about 0.75 mile northwest of well LE-5 (Nebraska Department of Natural Resources, 2020).

Of the six samples collected from wells screened in Paleozoic aquifers, all but one sample were characterized as calcium bicarbonate water type (well N-3; fig. 3, table 5A).
Well N-3 was characterized as calcium sulfate water type and had much higher total dissolved solids compared to other Paleozoic aquifers wells. The calcium-sulfate-rich water may be explained by the dissolution of gypsum, which was noted in the driller's log (Nebraska Department of Natural Resources, 2020). Except for well N-5, all Paleozoic aquifers water samples indicated oxic conditions (dissolved oxygen greater than $0.5 \mathrm{mg} / \mathrm{L}$ ).

The Kruskal-Wallis test was performed on selected constituents to determine if a group of samples collected from each of the three aquifers (Dakota aquifer, Niobrara aquifer, or Paleozoic aquifers) had significantly different distributions from the others. The calculated $p$-values from the tests are presented in table 6 . For this report, all values less than 0.05 are considered significant with 95 -percent confidence. Results indicated that the distributions of one of the three aquifer sample groups were significantly different for specific conductance; dissolved oxygen; iron; strontium; uranium; and nutrients, including nitrate plus nitrite as $\mathrm{N}$, ammonia $\left(\mathrm{NH}_{3}+\mathrm{NH}_{4}^{+}\right)$, and orthophosphate as phosphorus (table 6). Because the Kruskal-Wallis test is unable to discern which of the three groups' distributions were significantly different, there is some ambiguity in the results; however, some useful insights can be interpreted. Examining the water-quality data presented in tables $5 A$ and $5 B$, it can be determined that most of the samples collected from the Paleozoic aquifers were calcium bicarbonate water type and typically had high dissolved oxygen concentrations, low specific conductance, and low concentrations of trace elements including iron and uranium.

Samples collected from wells completed in the Dakota aquifer were subdivided into two groups based on water type: calcium bicarbonate and all other water types. The Wilcoxon Rank Sum test was completed to determine if the distributions of selected constituent were statistically significant between the two Dakota aquifer subgroups. The $p$-values are presented in table 6 and indicate that differences between the distributions for all selected field properties and constituents are significant. Given these results, the samples from the Dakota aquifer were subdivided into two groups when discussed in the remainder of this report: (1) Dakota aquifer (noncalcium bicarbonate water type) and (2) Dakota aquifer (calcium bicarbonate water type).

A Wilcoxon Rank Sum test was completed to determine if the distributions of selected constituents were statistically significant between two samples groups for the Niobrara and Paleozoic aquifers: (1) calcium bicarbonate dominant samples and (2) calcium sulfate dominant samples (table 6). The $p$-values presented in table 6 indicate that differences between the distributions for all selected field properties and constituents are insignificant, with the exception of specific conductance. Given these results, samples dominated by calcium sulfate had higher specific conductance, and by inference total dissolved solids, compared to samples dominated by calcium bicarbonate. 
Table 5A. Results of water-quality analyses for selected constituents, eastern Nebraska, 2016-18.

[ft, foot; BLS, below land surface; SC, specific conductance; $\mu \mathrm{S} / \mathrm{cm}$, microsiemen per centimeter; WT, water temperature; ${ }^{\circ} \mathrm{C}$, degrees Celsius; mg/L, milligram per liter; DO, dissolved oxygen; TDS, total dissolved solids; $\mathrm{Ca}$, calcium; $\mathrm{Mg}$, magnesium; $\mathrm{K}$, potassium; $\mathrm{Na}$, sodium; $\mathrm{CaCO}_{3}$, calcium carbonate; $\mathrm{HCO}_{3}$, bicarbonate; $\mathrm{SO}_{4}$, sulfate; $\mathrm{M}$, dissolved oxygen reading from instrument was negative, indicating the actual dissolved oxygen value was less than $0.1 \mathrm{mg} / \mathrm{L} ; \mathrm{Na}$, sodium]

\begin{tabular}{|c|c|c|c|c|c|c|c|c|c|c|c|c|c|c|}
\hline \multirow[b]{2}{*}{ Site number } & \multirow[b]{2}{*}{ Field name } & \multirow{2}{*}{$\begin{array}{c}\text { Well } \\
\text { depth } \\
\text { (ft BLS) }\end{array}$} & \multirow{2}{*}{$\begin{array}{c}\text { Date } \\
\text { sampled }\end{array}$} & \multirow{2}{*}{$\begin{array}{c}\text { Dominant } \\
\text { water type }\end{array}$} & \multirow{2}{*}{$\begin{array}{c}\text { pH, } \\
\text { standard } \\
\text { units }\end{array}$} & \multirow[b]{2}{*}{$\begin{array}{c}S C \\
(\mu S / c m)\end{array}$} & \multirow{2}{*}{$\begin{array}{l}\text { WT } \\
\left({ }^{\circ} \mathrm{C}\right)\end{array}$} & \multicolumn{7}{|c|}{ Concentration, in mg/L } \\
\hline & & & & & & & & DO & TDS & Ca & $\mathbf{M g}$ & $\mathbf{K}$ & $\mathrm{Na}$ & $\begin{array}{l}\text { Alkalinity, } \\
\text { as } \mathrm{CaCO}_{3}\end{array}$ \\
\hline \multicolumn{15}{|c|}{ Dakota aquifer } \\
\hline 413618096322901 & LE-1 & 181 & $8 / 25 / 2016$ & $\mathrm{Ca}-\mathrm{HCO}_{3}$ & 7.3 & 624 & 12.3 & $\mathrm{M}$ & 305 & 82 & 15.3 & 6.38 & 30.1 & 292 \\
\hline 413639096274901 & $\mathrm{LE}-2$ & 220 & $8 / 25 / 2016$ & $\mathrm{Ca}-\mathrm{HCO}_{3}$ & 7 & 867 & 12 & 0.2 & 425 & 116 & 23 & 10 & 52.3 & 333 \\
\hline 413912096462201 & LE-3 & 526 & $8 / 24 / 2016$ & $\mathrm{Ca}-\mathrm{Na}-\mathrm{SO}_{4}$ & 6.8 & 2,500 & 13.9 & 0 & 1,880 & 279 & 51.9 & 30.9 & 246 & 185 \\
\hline 413828096465801 & LE-4 & 239 & $8 / 24 / 2016$ & $\mathrm{Ca}-\mathrm{HCO}_{3}$ & 6.8 & 851 & 13.7 & 0 & 402 & 128 & 27.9 & 7.74 & 28.6 & 365 \\
\hline 424611097185201 & $\begin{array}{l}\text { LC-6S } \\
\text { domestic }\end{array}$ & 95 & $8 / 11 / 2016$ & $\mathrm{Ca}-\mathrm{SO}_{4}$ & 6.7 & 1,750 & 11.1 & 0.1 & 1,360 & 388 & 36.1 & 6.27 & 28.7 & 303 \\
\hline 423317097160901 & $\mathrm{LC}-4 \mathrm{M}$ & 730 & $8 / 10 / 2016$ & $\mathrm{Ca}-\mathrm{SO}_{4}$ & 7.1 & 1,560 & 19.5 & 0.1 & 1,170 & 219 & 39.2 & 24.2 & 91.7 & 149 \\
\hline 424713097170101 & LC-6M & 520 & $8 / 9 / 2016$ & $\mathrm{Ca}-\mathrm{SO}_{4}$ & 7.1 & 1,470 & 17.2 & $\mathrm{M}$ & 1,150 & 242 & 41.8 & 17 & 46.7 & 138 \\
\hline 424713097170102 & LC-6D & 750 & $8 / 9 / 2016$ & $\mathrm{Ca}-\mathrm{SO}_{4}$ & 6.9 & 1,610 & 18.2 & 0 & 1,300 & 275 & 45.3 & 15.7 & 53.3 & 137 \\
\hline 421730096390001 & PM D-1 & 440 & $8 / 11 / 2016$ & $\mathrm{Ca}-\mathrm{HCO}_{3}$ & 7 & 739 & 14 & M & 367 & 115 & 22.9 & 9.3 & 22.6 & 344 \\
\hline 410002096551101 & LPS-5 & 162 & $10 / 27 / 2016$ & $\mathrm{Ca}-\mathrm{SO}_{4}$ & 6.8 & 1,400 & 13.1 & 0.4 & 943 & 183 & 78.5 & 15 & 32 & 337 \\
\hline 411005096311701 & LPN-1 & 206 & $4 / 11 / 2017$ & $\mathrm{Na}-\mathrm{SO}_{4}$ & 7.2 & 3,600 & 14 & 0.1 & 2,540 & 232 & 47.1 & 32.3 & 537 & 186 \\
\hline 410335096150101 & D-SWSarpy1 & 117 & $10 / 3 / 2016$ & $\mathrm{Ca}-\mathrm{HCO}_{3}$ & 6.7 & 473 & 12.9 & 9.1 & 212 & 64.7 & 13.5 & 4.41 & 25.9 & 252 \\
\hline 410613096071101 & D-Sp1 & 215 & $9 / 28 / 2016$ & $\mathrm{Ca}-\mathrm{HCO}_{3}$ & 6.5 & 493 & 14.2 & 5.4 & 273 & 65.1 & 18 & 3.02 & 16.9 & 245 \\
\hline 410613096071102 & D-Sp2 & 125 & $9 / 28 / 2016$ & $\mathrm{Ca}-\mathrm{HCO}_{3}$ & 6.9 & 456 & 15.8 & 0.7 & 276 & 55.9 & 11.5 & 2.98 & 24.4 & 211 \\
\hline 411845096211203 & D-Va3 & 204 & $3 / 9 / 2018$ & $\begin{array}{c}\mathrm{Ca}-\mathrm{Na}-\mathrm{SO}_{4^{-}} \\
\mathrm{HCO}_{3}\end{array}$ & 7.6 & 580 & 11.3 & 0.6 & 351 & 57.4 & 12.2 & 7.01 & 53 & 184 \\
\hline 412758096222801 & $\mathrm{D}-\mathrm{A} 1$ & 297 & $11 / 2 / 2016$ & $\mathrm{Ca}-\mathrm{Na}-\mathrm{SO}_{4}$ & 7.2 & 2,030 & 14.2 & M & 1,440 & 195 & 40 & 12.6 & 231 & 208 \\
\hline 415958096152201 & $\mathrm{D}-\mathrm{D} 1$ & 180 & $6 / 20 / 2018$ & $\mathrm{Ca}-\mathrm{HCO}_{3}$ & 6.5 & 808 & 11.4 & 0.1 & 414 & 109 & 25.6 & 7.5 & 37 & 334 \\
\hline 421406096294901 & D-Th1 & 370 & $10 / 14 / 2016$ & $\begin{array}{c}\mathrm{Ca}-\mathrm{SO}_{4^{-}} \\
\mathrm{HCO}_{3}\end{array}$ & 6.5 & 1,000 & 12.6 & 0.3 & 505 & 134 & 25.9 & 16.8 & 53.3 & 300 \\
\hline 421406096294902 & D-Th2 & 275 & $10 / 14 / 2016$ & $\mathrm{Ca}-\mathrm{HCO}_{3}$ & 6.9 & 867 & 13.1 & 0.1 & 409 & 121 & 22.8 & 14.3 & 40.6 & 333 \\
\hline 422616096343801 & $\mathrm{D}-\mathrm{J} 1$ & 470 & $10 / 13 / 2016$ & $\mathrm{Ca}-\mathrm{SO}_{4}$ & 7.1 & 2,060 & 13.8 & 0.6 & 1,570 & 242 & 44.8 & 27 & 172 & 176 \\
\hline 422616096343802 & $\mathrm{D}-\mathrm{J} 2$ & 280 & $10 / 13 / 2016$ & $\mathrm{Ca}-\mathrm{SO}_{4}$ & 6.9 & 1,340 & 16.1 & 0.2 & 981 & 174 & 35.2 & 16.9 & 81.9 & 323 \\
\hline 405921096535101 & LPS -3 & 212 & $11 / 10 / 2016$ & $\mathrm{Ca}-\mathrm{HCO}_{3}$ & 7.1 & 866 & 12.9 & 2.8 & 402 & 99 & 29.4 & 10.1 & 49.8 & 365 \\
\hline
\end{tabular}


Table 5A. Results of water-quality analyses for selected constituents, eastern Nebraska, 2016-18.-Continued

[ft, foot; BLS, below land surface; SC, specific conductance; $\mu \mathrm{S} / \mathrm{cm}$, microsiemen per centimeter; WT, water temperature; ${ }^{\circ} \mathrm{C}$, degrees Celsius; mg/L, milligram per liter; DO, dissolved oxygen; TDS, total dissolved solids; $\mathrm{Ca}$, calcium; $\mathrm{Mg}$, magnesium; $\mathrm{K}$, potassium; $\mathrm{Na}$, sodium; $\mathrm{CaCO}_{3}$, calcium carbonate; $\mathrm{HCO}_{3}$, bicarbonate; $\mathrm{SO}_{4}$, sulfate; $\mathrm{M}$, dissolved oxygen reading from instrument was negative, indicating the actual dissolved oxygen value was less than $0.1 \mathrm{mg} / \mathrm{L} ; \mathrm{Na}$, sodium]

\begin{tabular}{|c|c|c|c|c|c|c|c|c|c|c|c|c|c|c|}
\hline \multirow[b]{2}{*}{ Site number } & \multirow[b]{2}{*}{ Field name } & \multirow{2}{*}{$\begin{array}{c}\text { Well } \\
\text { depth } \\
\text { (ft BLS) }\end{array}$} & \multirow{2}{*}{$\begin{array}{c}\text { Date } \\
\text { sampled }\end{array}$} & \multirow{2}{*}{$\begin{array}{c}\text { Dominant } \\
\text { water type }\end{array}$} & \multirow{2}{*}{$\begin{array}{c}\text { pH, } \\
\text { standard } \\
\text { units }\end{array}$} & \multirow{2}{*}{$\underset{(\mu S / c m)}{S C}$} & \multirow{2}{*}{$\begin{array}{l}\text { WT } \\
\left({ }^{\circ} \mathrm{C}\right)\end{array}$} & \multicolumn{7}{|c|}{ Concentration, in mg/L } \\
\hline & & & & & & & & DO & TDS & $\mathrm{Ca}$ & $\mathbf{M g}$ & $\mathbf{K}$ & $\mathrm{Na}$ & $\begin{array}{l}\text { Alkalinity, } \\
\text { as } \mathrm{CaCO}_{3}\end{array}$ \\
\hline \multicolumn{15}{|c|}{ Niobrara aquifer } \\
\hline 423317097161001 & $\mathrm{LC}-4 \mathrm{~S}$ & 120 & $8 / 10 / 2016$ & $\mathrm{Ca}-\mathrm{HCO}_{3}$ & 7 & 706 & 12.7 & 0.3 & 397 & 100 & 25.2 & 11 & 18.6 & 272 \\
\hline 422344097120801 & LE-5 & 157 & $8 / 23 / 2016$ & $\mathrm{Ca}-\mathrm{SO}_{4}$ & 7 & 1,820 & 13.6 & 0.1 & 1,380 & 287 & 66 & 16.9 & 73.4 & 340 \\
\hline 422409097124601 & LE-6 & 180 & $8 / 23 / 2016$ & $\mathrm{Ca}-\mathrm{SO}_{4}$ & 7 & 1,090 & 11.9 & 1.6 & 646 & 148 & 39.9 & 6.3 & 27.7 & 306 \\
\hline \multicolumn{15}{|c|}{ Paleozoic aquifers } \\
\hline 405139096194801 & LPS-1 & 116 & $10 / 6 / 2016$ & $\mathrm{Ca}-\mathrm{HCO}_{3}$ & 6.9 & 542 & 15.2 & 7.6 & 297 & 70.2 & 13.2 & 2.01 & 34.5 & 289 \\
\hline 405213096205001 & LPS-2 & 130 & $10 / 6 / 2016$ & $\mathrm{Ca}-\mathrm{HCO}_{3}$ & 6.1 & 667 & 12.7 & 5.9 & 260 & 89.3 & 16.4 & 2.88 & 39.3 & 304 \\
\hline 402313095512401 & $\mathrm{~N}-3$ & 160 & $10 / 5 / 2016$ & $\mathrm{Ca}-\mathrm{SO}_{4}$ & 6.9 & 1,910 & 13.8 & 3 & 1,480 & 397 & 39.8 & 1.98 & 28.3 & 294 \\
\hline 401759096003301 & $\mathrm{~N}-5$ & 172 & $11 / 8 / 2016$ & $\mathrm{Ca}-\mathrm{HCO}_{3}$ & 6.9 & 928 & 13.3 & M & 392 & 113 & 37 & 6.33 & 50.1 & 396 \\
\hline 404950096205501 & LPS-4 & 110 & $10 / 5 / 2016$ & $\mathrm{Ca}-\mathrm{HCO}_{3}$ & 6.9 & 654 & 12.7 & 11 & 422 & 86 & 17.7 & 1.96 & 37.9 & 291 \\
\hline 401819095493701 & $\mathrm{~N}-6$ & 79 & $11 / 8 / 2016$ & $\mathrm{Ca}-\mathrm{HCO}_{3}$ & 7.1 & 663 & 13.5 & 8.5 & 332 & 80.6 & 23.7 & 1.36 & 32.2 & 243 \\
\hline
\end{tabular}


Table 5B. Results of water-quality analyses for selected constituents, eastern Nebraska, 2016-18.

[ft, foot; BLS, below land surface; mg/L, milligram per liter; $\mu \mathrm{g} / \mathrm{L}$, microgram per liter; $\mathrm{Cl}$, chloride; $\mathrm{Fl}$, fluoride; $\mathrm{SO}_{4}$, sulfate; $\mathrm{N}$, nitrogen; $\mathrm{NH}_{3}$, ammonia; $\mathrm{NH}_{4}{ }^{+}$, ammonium; $\mathrm{P}$, phosphorus; $\mathrm{Fe}$, iron; $\mathrm{Mn}$, manganese; Mo, molybdenum; Sr, strontium; As, arsenic; $\mathrm{U}$, uranium; $\delta^{2} \mathrm{H}$, hydrogen isotope ratio in per mil Vienna Standard Mean Ocean Water; $\delta^{18} \mathrm{O}$, oxygen isotope ratio in per mil Vienna Standard Mean Ocean Water; <, less than; --, analyte not sampled]

\begin{tabular}{|c|c|c|c|c|c|c|c|c|c|c|c|c|c|c|c|c|}
\hline \multirow[b]{2}{*}{ Site number } & \multirow[b]{2}{*}{ Field name } & \multirow[b]{2}{*}{$\begin{array}{c}\text { Well } \\
\text { depth } \\
\text { (ft } \\
\text { BLS) }\end{array}$} & \multicolumn{7}{|c|}{ Concentration, in mg/L } & \multicolumn{5}{|c|}{ Concentration in $\mu \mathrm{g} / \mathrm{L}$} & \multicolumn{2}{|c|}{ Stable isotopes } \\
\hline & & & Cl & $\mathbf{F I}$ & $\mathrm{SO}_{4}$ & $\begin{array}{l}\text { Nitrate } \\
\text { plus } \\
\text { nitrite, } \\
\text { as N }\end{array}$ & $\begin{array}{c}\text { Ammonia } \\
\left(\mathrm{NH}_{3}+\right. \\
\left.\mathrm{NH}_{4}+\right)\end{array}$ & $\begin{array}{c}\text { Ortho- } \\
\text { phosphate, } \\
\text { as P }\end{array}$ & $\mathrm{Fe}$ & Mn & Mo & Sr & As & $\mathbf{U}$ & $\begin{array}{c}\delta^{2} \mathrm{H}, \\
\text { per mil }\end{array}$ & $\begin{array}{c}\delta^{180}, \\
\text { per mil }\end{array}$ \\
\hline \multicolumn{17}{|c|}{ Dakota aquifer } \\
\hline 413618096322901 & LE-1 & 181 & 5.21 & 0.29 & 47.8 & $<0.040$ & 0.22 & 0.057 & 786 & 530 & 1.3 & 639 & 0.09 & 0.05 & -54.9 & -8.13 \\
\hline 413639096274901 & LE-2 & 220 & 17.1 & 1.22 & 116 & $<0.040$ & 0.35 & 0.033 & 756 & 224 & 2.3 & 1,790 & 4.7 & 1.05 & -58.6 & -8.58 \\
\hline 413912096462201 & LE-3 & 526 & 133 & 1.96 & 927 & $<0.040$ & 0.82 & $<0.004$ & 1,650 & 111 & 3.81 & 6,850 & 1.7 & 0.14 & -109 & -14.45 \\
\hline 413828096465801 & LE-4 & 219 & 3.2 & 0.33 & 111 & 0.179 & 0.6 & 0.032 & 417 & 303 & 2.22 & 1,340 & 0.34 & 1.04 & -63.7 & -9.26 \\
\hline 424611097185201 & $\begin{array}{l}\text { LC-6S } \\
\quad \text { domestic }\end{array}$ & 95 & 5.41 & 0.46 & 746 & 1.58 & 0.01 & $<0.004$ & 35.8 & 3.42 & 55.6 & 2,100 & 0.71 & 37.8 & -66.7 & -9.64 \\
\hline 423317097160901 & $\mathrm{LC}-4 \mathrm{M}$ & 730 & 37.5 & 2.33 & 672 & $<0.040$ & 0.69 & $<0.004$ & 1,550 & 74.8 & 2.88 & 5,130 & 2.5 & 0.07 & -126 & -16.71 \\
\hline 424713097170101 & $\mathrm{LC}-6 \mathrm{M}$ & 520 & 38.5 & 1.9 & 653 & $<0.040$ & 0.13 & $<0.004$ & 1,630 & 156 & 5.28 & 4,510 & 2.7 & $<0.050$ & -126 & -16.97 \\
\hline 424713097170102 & $\mathrm{LC}-6 \mathrm{D}$ & 750 & 51.3 & 1.61 & 699 & $<0.040$ & 0.07 & $<0.004$ & 1,640 & 150 & 5.36 & 4,590 & 3 & 0.07 & -- & -- \\
\hline 421730096390001 & PM D-1 & 440 & 3.24 & 0.68 & 74.5 & 0.042 & 0.29 & 0.019 & 358 & 224 & 1.28 & 1,670 & 0.13 & 0.32 & -68 & -9.89 \\
\hline 410002096551101 & LPS-5 & 162 & 4.6 & 0.37 & 486 & $<0.040$ & 1.24 & 0.052 & 879 & 817 & 2.69 & 1,690 & 2.2 & 1.18 & -59.1 & -8.95 \\
\hline 411005096311701 & LPN-1 & 206 & 472 & 1.9 & 976 & $<0.040$ & 1.17 & 0.006 & 1,300 & 197 & 4.32 & 6,940 & 2.5 & 0.189 & -112 & -14.76 \\
\hline 410335096150101 & D-SWSarpy1 & 117 & 2.37 & 0.29 & 6.19 & 2.14 & $<0.01$ & 0.205 & 7.7 & $<0.40$ & 2.34 & 275 & 0.8 & 3.13 & -- & -- \\
\hline 410613096071101 & D-Sp1 & 215 & 1.63 & 0.23 & 19.9 & 3.11 & $<0.01$ & 0.145 & 33.3 & 2.18 & 2.47 & 258 & 1.5 & 1.61 & -- & -- \\
\hline 410613096071102 & D-Sp2 & 125 & 1.44 & 0.24 & 17.5 & 2.55 & $<0.01$ & 0.117 & 29.6 & 223 & 6.78 & 261 & 1.8 & 1.37 & -- & -- \\
\hline 411845096211203 & D-Va3 & 204 & 16.9 & 0.67 & 98.2 & $<0.040$ & 0.15 & 0.006 & 604 & 83.9 & 1.54 & 873 & 0.37 & 0.096 & -- & -- \\
\hline 412758096222801 & $\mathrm{D}-\mathrm{A} 1$ & 297 & 112 & 0.77 & 723 & $<0.040$ & 0.51 & 0.014 & 1,020 & 681 & 3.44 & 3,400 & 1.9 & 0.746 & -92.4 & -12.49 \\
\hline 415958096152201 & D-D1 & 180 & 11 & 0.6 & 110 & $<0.040$ & 0.15 & 0.013 & 795 & 142 & 0.89 & 1,400 & 0.56 & 3.9 & -- & -- \\
\hline 421406096294901 & D-Th1 & 370 & 27.3 & 1.34 & 178 & $<0.040$ & 0.42 & 0.038 & 993 & 143 & 1.87 & 2,960 & 1.3 & 0.08 & -- & -- \\
\hline 421406096294902 & D-Th2 & 275 & 17.5 & 1.26 & 106 & $<0.040$ & 0.37 & 0.009 & 861 & 158 & 2.05 & 2,340 & 0.74 & 0.09 & -- & -- \\
\hline 422616096343801 & D-J1 & 270 & 116 & 2.26 & 804 & 0.045 & 0.63 & 0.029 & 1,420 & 316 & 6.38 & 6,540 & 1.3 & 0.219 & -- & -- \\
\hline 422616096343802 & D-J2 & 280 & 50.5 & 1.27 & 375 & $<0.040$ & 0.45 & 0.056 & 622 & 435 & 6.78 & 3,130 & 1.6 & 0.614 & -- & -- \\
\hline 405921096535101 & LPS -3 & 212 & 20 & 0.42 & 105 & $<0.040$ & 1.12 & 0.01 & 348 & 420 & 4.03 & 905 & 18 & 0.751 & -58.9 & -8.84 \\
\hline
\end{tabular}


Table 5B. Results of water-quality analyses for selected constituents, eastern Nebraska, 2016-18.-Continued

[ft, foot; BLS, below land surface; mg/L, milligram per liter; $\mu \mathrm{g} / \mathrm{L}$, microgram per liter; $\mathrm{Cl}$, chloride; $\mathrm{Fl}$, fluoride; $\mathrm{SO}_{4}$, sulfate; $\mathrm{N}$, nitrogen; $\mathrm{NH}_{3}$, ammonia; $\mathrm{NH}_{4}{ }^{+}$, ammonium; $\mathrm{P}$, phosphorus; $\mathrm{Fe}$, iron; $\mathrm{Mn}$, manganese; Mo, molybdenum; Sr, strontium; As, arsenic; $\mathrm{U}$, uranium; $\delta^{2} \mathrm{H}$, hydrogen isotope ratio in per mil Vienna Standard Mean Ocean Water; $\delta^{18} \mathrm{O}$, oxygen isotope ratio in per mil Vienna Standard Mean Ocean Water; <, less than; --, analyte not sampled]

\begin{tabular}{|c|c|c|c|c|c|c|c|c|c|c|c|c|c|c|c|c|}
\hline \multirow[b]{2}{*}{ Site number } & \multirow[b]{2}{*}{ Field name } & \multirow[b]{2}{*}{$\begin{array}{c}\text { Well } \\
\text { depth } \\
\text { (ft } \\
\text { BLS) }\end{array}$} & \multicolumn{7}{|c|}{ Concentration, in mg/L } & \multicolumn{5}{|c|}{ Concentration in $\mu \mathrm{g} / \mathrm{L}$} & \multicolumn{2}{|c|}{ Stable isotopes } \\
\hline & & & Cl & $\mathbf{F I}$ & $\mathrm{SO}_{4}$ & $\begin{array}{l}\text { Nitrate } \\
\text { plus } \\
\text { nitrite, } \\
\text { as N }\end{array}$ & $\begin{array}{c}\text { Ammonia } \\
\left(\mathrm{NH}_{3}+\right. \\
\left.\mathrm{NH}_{4}+\right)\end{array}$ & $\begin{array}{c}\text { Ortho- } \\
\text { phosphate, } \\
\text { as P }\end{array}$ & $\mathrm{Fe}$ & Mn & Mo & $\mathrm{Sr}$ & As & $\mathbf{U}$ & $\begin{array}{c}\delta^{2} \mathrm{H}, \\
\text { per mil }\end{array}$ & $\begin{array}{c}\delta^{18} 0, \\
\text { per mil }\end{array}$ \\
\hline \multicolumn{17}{|c|}{ Niobrara aquifer } \\
\hline 423317097161001 & $\mathrm{LC}-4 \mathrm{~S}$ & 120 & 2.65 & 0.71 & 103 & $<0.040$ & 0.03 & 0.008 & 319 & 147 & 15.3 & 957 & 1.7 & 1.71 & -81.1 & -11.4 \\
\hline 422344097120801 & LE-5 & 157 & 5.32 & 0.32 & 700 & $<0.040$ & 0.05 & 0.035 & 9.9 & 868 & 4.88 & 1,510 & 1.4 & 41.3 & -61.6 & -8.83 \\
\hline 422409097124601 & LE-6 & 180 & 8.9 & 0.28 & 225 & 13.6 & $<0.01$ & 0.059 & 8.5 & $<0.40$ & 1.82 & 757 & 1.1 & 21.4 & -68.3 & -10.07 \\
\hline \multicolumn{17}{|c|}{ Paleozoic aquifers } \\
\hline 405139096194801 & LPS-1 & 116 & 2.58 & 0.31 & 9.62 & 1.89 & $<0.01$ & 0.061 & $<5.0$ & $<0.40$ & 0.83 & 355 & 0.41 & 3.34 & -42.7 & -6.75 \\
\hline 405213096205001 & LPS-2 & 130 & 13.2 & 0.32 & 15 & $<0.040$ & 0.16 & 0.082 & 761 & 99.7 & 2.1 & 627 & 8.5 & 0.065 & -49.7 & -7.71 \\
\hline 402313095512401 & $\mathrm{~N}-3$ & 160 & 32.6 & 0.27 & 807 & 4.17 & $<0.01$ & 0.009 & 19.3 & 1.54 & 14.8 & 6,150 & 1.2 & 3.74 & -44.5 & -6.92 \\
\hline 401759096003301 & $\mathrm{~N}-5$ & 172 & 15.1 & 0.49 & 93 & 1.77 & 0.36 & 0.035 & 45 & 200 & 45.4 & 1,010 & 10.9 & 3.43 & -43.9 & -6.88 \\
\hline 404950096205501 & LPS-4 & 110 & 2.08 & 0.32 & 35 & 10.4 & $<0.01$ & 0.351 & 5.6 & 1.31 & 0.12 & 726 & 19.8 & 23.5 & -46.9 & -7.34 \\
\hline 401819095493701 & $\mathrm{~N}-6$ & 79 & 6.59 & 0.31 & 35.9 & 16.8 & $<0.01$ & 0.025 & 7.4 & $<0.40$ & 0.536 & 415 & 0.88 & 0.504 & -41.4 & -6.45 \\
\hline
\end{tabular}


Table 6. Results from the Krustal-Wallis and Wilcoxon Rank Sum statistical tests for selected field properties and constituents.

[SC, specific conductance; DO, dissolved oxygen; Fe, iron; Mn, manganese; As, arsenic; Mo, molybdenum; Sr, strontium; Se, selenium; U, uranium; Dakota, Dakota aquifer; Niobrara, Niobrara aquifer; Paleozoic, Paleozoic aquifers; $\mathrm{N}$, nitrogen; $\mathrm{NH}_{3}$, ammonia; $\mathrm{NH}_{4}^{+}$, ammonium]

\begin{tabular}{|c|c|c|c|c|c|c|c|c|c|c|c|c|c|}
\hline \multirow[b]{3}{*}{ Group } & \multirow[b]{3}{*}{$\begin{array}{c}\text { Statistical } \\
\text { test }\end{array}$} & \multicolumn{12}{|c|}{ Statistical test results ( $p$-values) for selected field properties and constituents } \\
\hline & & \multirow[b]{2}{*}{ SC } & \multirow[b]{2}{*}{ DO } & \multicolumn{7}{|c|}{ Trace element } & \multicolumn{3}{|c|}{ Nutrient } \\
\hline & & & & Fe & Mn & As & Mo & Sr & Se & $\mathbf{U}$ & $\begin{array}{l}\text { Nitrate } \\
\text { plus } \\
\text { nitrite, } \\
\text { as } \mathrm{N}\end{array}$ & $\begin{array}{c}\text { Ammonia } \\
\left(\mathrm{NH}_{3}+\mathrm{NH}_{4}^{+}\right)\end{array}$ & $\begin{array}{c}\text { Ortho- } \\
\text { phosphate, } \\
\text { as } \\
\text { phosphorus }\end{array}$ \\
\hline $\begin{array}{l}\text { Dakota, Niobrara, and } \\
\text { Paleozoic (all water } \\
\text { types) }\end{array}$ & $\begin{array}{l}\text { Kruskal- } \\
\text { Wallis }\end{array}$ & ${ }^{1} 0.0030$ & ${ }^{1} 0.0241$ & ${ }^{1} 0.0006$ & 0.1040 & 0.3861 & 0.1859 & ${ }^{1} 0.0025$ & 0.2882 & ${ }^{1} 0.0268$ & ${ }^{1} 0.0210$ & ${ }^{1} 0.0085$ & ${ }^{1} 0.0409$ \\
\hline $\begin{array}{l}\text { Dakota (calcium } \\
\text { bicarbonate) and } \\
\text { Dakota (noncalcium } \\
\text { bicarbonate) }\end{array}$ & $\begin{array}{l}\text { Wilcoxon } \\
\text { Rank } \\
\text { Sum }\end{array}$ & ${ }^{1} 0.0005$ & ${ }^{1} 0.0137$ & ${ }^{1} 0.0005$ & ${ }^{1} 0.0005$ & ${ }^{1} 0.0025$ & ${ }^{1} 0.0005$ & ${ }^{1} 0.0005$ & ${ }^{1} 0.0023$ & ${ }^{1} 0.0025$ & ${ }^{1} 0.0012$ & ${ }^{1} 0.0005$ & ${ }^{1} 0.0023$ \\
\hline $\begin{array}{l}\text { Niobrara and Paleozoic } \\
\text { (calcium bicarbon- } \\
\text { ate) and Niobrara } \\
\text { and Paleozoic } \\
\text { (calcium sulfate) }\end{array}$ & $\begin{array}{l}\text { Wilcoxon } \\
\text { Rank } \\
\text { Sum }\end{array}$ & ${ }^{1} 0.0238$ & 0.3810 & 1.0000 & 0.8955 & 0.5476 & 0.7143 & 0.0952 & 0.6973 & 0.0952 & 0.8955 & 0.6714 & 0.6041 \\
\hline
\end{tabular}

${ }^{1}$ Statistically significant difference. 


\section{Nutrients}

Sampling results for nutrients, which include nitrate plus nitrite as nitrogen (hereinafter referred to as "nitrate") and orthophosphate as phosphorous (hereinafter referred to as "orthophosphate"), are presented in table $5 B$. Of the 31 samples collected from the three bedrock aquifers, 18 wells had concentrations of nitrate that were below the detection limit of $0.040 \mathrm{mg} / \mathrm{L}$. In general, nitrate concentrations for the Dakota aquifer were the lowest of the three aquifer groups and all samples were below the EPA maximum contaminant level of $10 \mathrm{mg} / \mathrm{L}$. One of the three samples collected for the Niobrara aquifer and two of the six samples collected from the Paleozoic aquifers exceeded the $10 \mathrm{mg} / \mathrm{L}$ EPA maximum contaminant level for nitrate (table 5).

Nitrate in groundwater is often the primary contaminant of concern for local water managers and users because land use in eastern Nebraska is dominated by row-crop agriculture. For this report, the background nitrate concentration is assumed to be less than $2 \mathrm{mg} / \mathrm{L}$ (Mueller and Helsel, 1996). Denitrification may play a role in reducing nitrate concentrations in secondary bedrock aquifers in eastern Nebraska. Denitrification is an important microbially mediated natural attenuation process where anaerobic microorganisms, in the absence of dissolved oxygen, reduce nitrate to generate energy and nitrogen gas (Green and Bekins, 2010). Dissolved oxygen measurements can be used to assess the prevalence of denitrification and to predict the extent to which natural attenuation may help control nitrate concentrations in groundwater.

Dissolved oxygen and nitrate concentrations are plotted against well depth for water samples from both Dakota aquifer subgroups, the Niobrara aquifer, and the Paleozoic aquifers (figs. $5 A$ and $5 B$, table $5 A$ and $5 B$ ). Of the 31 wells sampled, 12 wells had dissolved oxygen concentrations of $0.5 \mathrm{mg} / \mathrm{L}$ or greater and 7 sampled wells had nitrate concentrations that exceeded $2.0 \mathrm{mg} / \mathrm{L}$ (figs. $5 A$ and $5 B$ ). For this report, groundwater with dissolved oxygen concentrations less than $0.5 \mathrm{mg} / \mathrm{L}$ is considered anoxic. Samples in table 5 were coded as " $\mathrm{M}$ " when the instrument used measured dissolved oxygen concentrations of less than $0 \mathrm{mg} / \mathrm{L}$. The less than $0 \mathrm{mg} / \mathrm{L}$ measured values for dissolved oxygen occurred because the 1-point calibration of the sensor was completed at 100-percent saturation (U.S. Geological Survey, 2020a) and, therefore, may not predict the dissolved oxygen concentration as accurately when values approach $0 \mathrm{mg} / \mathrm{L}$. Samples coded as " $\mathrm{M}$ " were assumed to be $0 \mathrm{mg} / \mathrm{L}$ for statistical analyses and in figure $5 \mathrm{~A}$. Generally, groundwater samples collected from wells screened deeper than $220 \mathrm{ft}$ had dissolved oxygen concentration that were less than or approximately equal to $0.5 \mathrm{mg} / \mathrm{L}$, and all wells screened deeper than $270 \mathrm{ft}$ had dissolved oxygen concentrations less than $0.5 \mathrm{mg} / \mathrm{L}$. Of the 10 Dakota aquifer (calcium bicarbonate) wells, 4 have dissolved oxygen concentrations greater than $0.5 \mathrm{mg} / \mathrm{L}$, compared to only 2 of the 12 Dakota aquifer (noncalcium bicarbonate) wells. The highest dissolved oxygen concentration for Dakota aquifer (calcium bicarbonate) wells was $9.1 \mathrm{mg} / \mathrm{L}$ and for the Dakota aquifer (noncalcium bicarbonate) wells was $0.6 \mathrm{mg} / \mathrm{L}$ (table 5A).

Nitrate concentrations plotted against well depth indicate that concentrations for wells deeper than $200 \mathrm{ft}$ are below the background concentration of $2 \mathrm{mg} / \mathrm{L}$ (Mueller and Helsel, 1996) and are often below the detection limit of $0.040 \mathrm{mg} / \mathrm{L}$. Of the 12 Dakota aquifer (noncalcium bicarbonate) wells sampled, only two wells had nitrate concentrations above the detection limit, and all were below the background concentration of $2 \mathrm{mg} / \mathrm{L}$ (Mueller and Helsel, 1996; fig. 5B). Three of the 10 Dakota aquifer (calcium bicarbonate) wells had nitrate concentrations above the background concentration of $2 \mathrm{mg} / \mathrm{L}$ (fig. $5 B$, tables $5 A$ and $5 B$ ). The only Niobrara aquifer sample with measurable dissolved oxygen concentrations had a nitrate concentration of $13.6 \mathrm{mg} / \mathrm{L}$, which exceeds the EPA maximum contaminant level of $10 \mathrm{mg} / \mathrm{L}$ (fig. $5 A$ and $5 B$, tables $5 A$ and $5 B$ ). Sampled wells completed in Paleozoic aquifers, which have well depths that range from 79 to $172 \mathrm{ft}$, had some of the highest concentrations of nitrate compared to the other aquifer groups, with nitrate in three of the six wells exceeding the background nitrate concentration of $2 \mathrm{mg} / \mathrm{L}$, and nitrate concentrations in two of the six wells exceeding the EPA maximum contaminant level of $10 \mathrm{mg} / \mathrm{L}$ (fig. $5 B$, tables $5 A$ and $5 B$ ).

\section{Stable Isotopes}

Stable isotope data from samples collected from wells completed in the Dakota aquifer (including both subgroups), Niobrara aquifer, and Paleozoic aquifers tend to cluster together along the LMWL from Mead, Nebr. (fig. 6; Harvey, 2001). Generally, samples collected in the northern part of the study area are isotopically depleted, and samples collected in the southern part of the study area are isotopically enriched (table 5B). The latitudinal effect described in Clark and Fritz (1997) states that for every degree of increase in latitude, $\delta^{18} \mathrm{O}$ decreases by approximately 0.6 per mil. The latitude effect explains some, but not all, of the variability in $\delta^{18} \mathrm{O}$ values in figure 6.

The seasonality of recharged groundwater likely plays a role because the northern part of the study area receives more snow fall compared to the southern part of the study area. Examining the data from both Dakota aquifer subgroups, the samples from the Dakota aquifer (noncalcium bicarbonate) subgroup are generally more isotopically depleted compared to the samples from the Dakota aquifer (calcium bicarbonate) subgroup (fig. 6). Some of the most isotopically depleted water samples were collected in Lewis and Clark NRD in the northern part of the study area (fig. 1), which is consistent with samples collected by Gosselin and others (2001) in that area. Values of $\delta^{18} \mathrm{O}$ are known to be temperature dependent; globally colder regions have more isotopically depleted $\delta^{18} \mathrm{O}$ compared to more temperate regions (Clark and Fritz, 1997). The values of the most isotopically depleted samples from the 


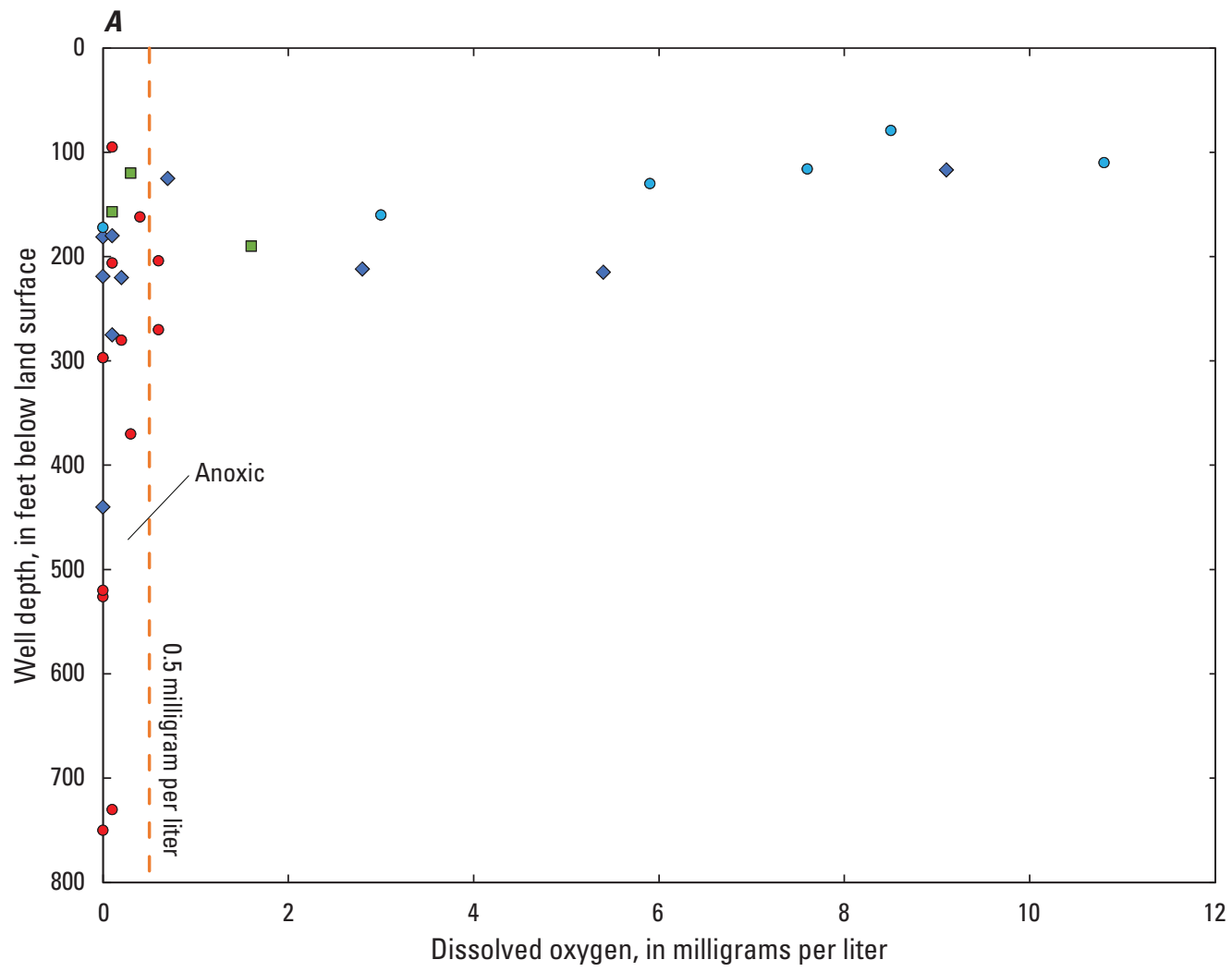

\section{EXPLANATION}

- Dakota aquifer-Noncalcium bicarbonate

- Dakota aquifer-Calcium bicarbonate

- Niobrara aquifer

- Paleozoic aquifers

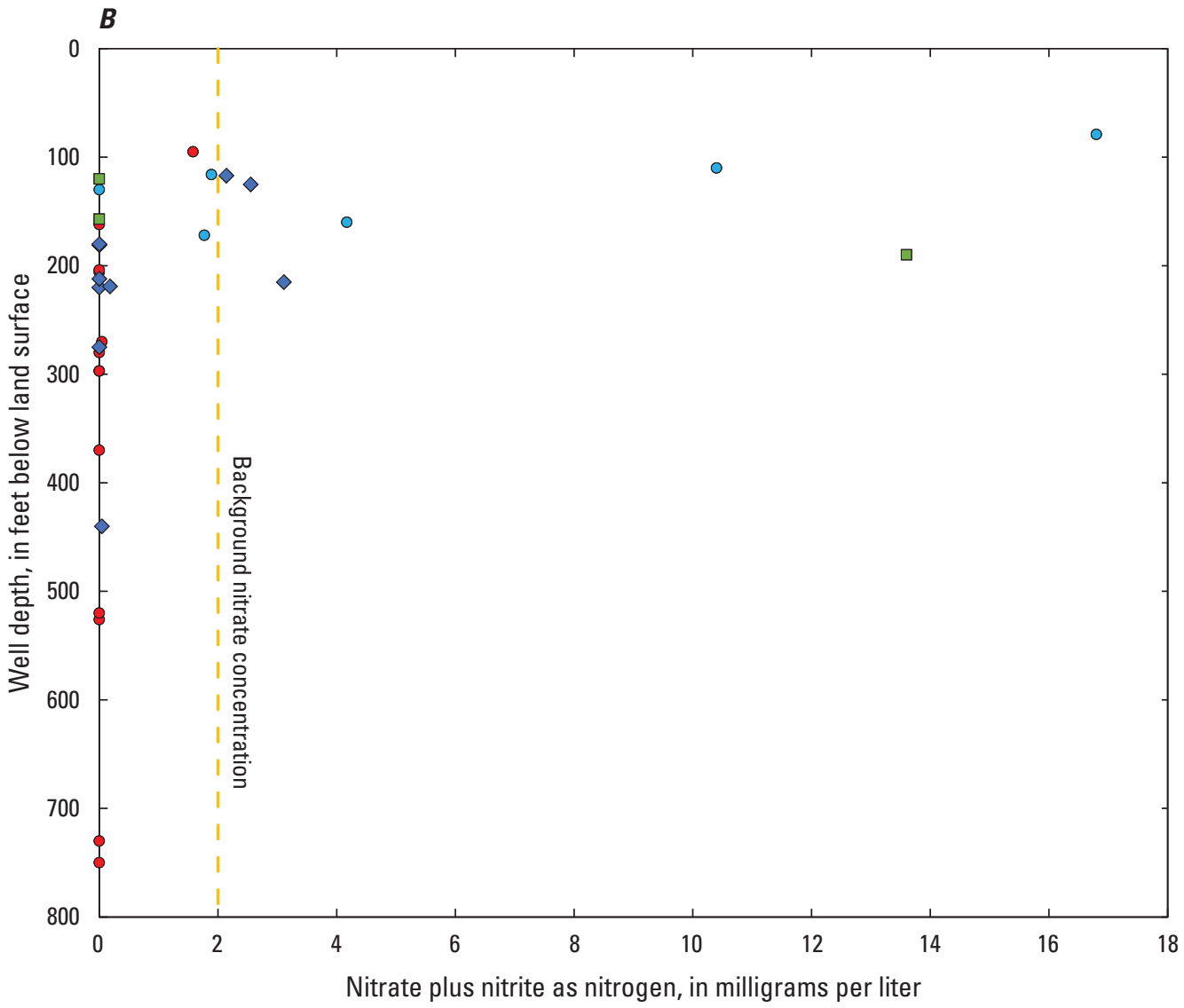

Figure 5. Concentrations from sampled wells against well depth, eastern Nebraska, 2016-18. $A$, Dissolved oxygen. $B$, Nitrate plus nitrite as nitrogen. 


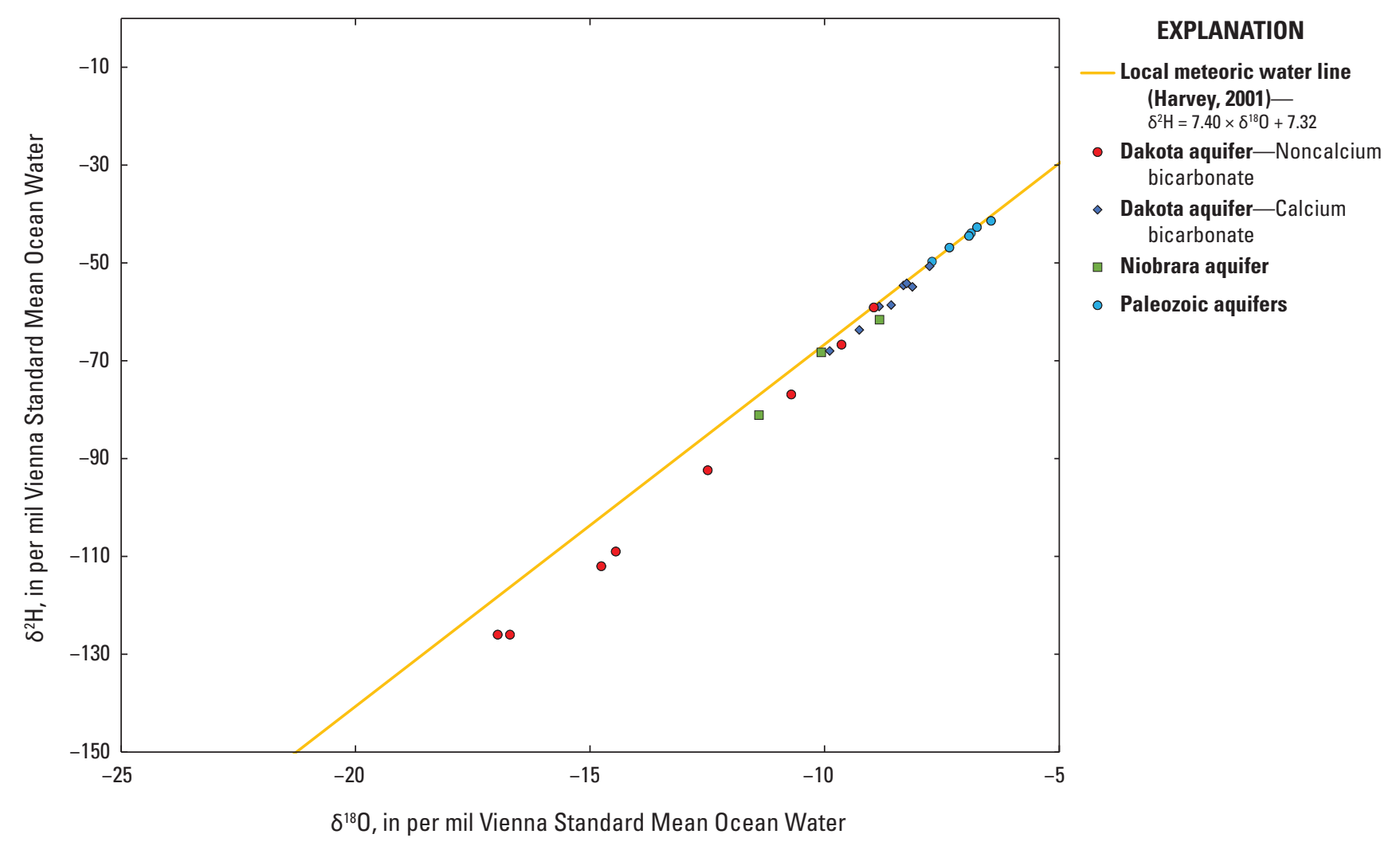

Figure 6. Stable isotopes of oxygen $\left(\delta^{18} 0\right)$ and hydrogen $\left(\delta^{2} H\right)$ from sampled wells, eastern Nebraska, 2016-18.

Dakota aquifer (noncalcium bicarbonate) subgroup indicate the climate at the time of recharge was approximately $15^{\circ} \mathrm{C}$ cooler than present day (2020) climate. Samples from the Dakota aquifer (calcium bicarbonate) subgroup are isotopically enriched and are similar to modern precipitation (fig. 6). Samples collected from Paleozoic units were the most isotopically enriched of any aquifer group, indicating groundwater is recharged by more summertime precipitation compared to other aquifer groups (table 5B).

\section{Groundwater Age}

Groundwater age tracer results indicated that samples from the Dakota aquifer (noncalcium bicarbonate) subgroup generally had lower values of percent Modern Carbon (fig. 7) and had older radiocarbon ages (table 7, fig. 8) compared to samples from the Dakota aquifer (calcium bicarbonate) subgroup. Of the 11 samples from the Dakota aquifer (noncalcium bicarbonate) subgroup where ${ }^{14} \mathrm{C}$ samples were collected, 3 were considered modern (post-1950). The oldest radiocarbon ages estimated in this report are from samples of four Dakota aquifer (noncalcium bicarbonate) subgroup wells located in Cedar County (figs. 1 and 8, table 7) and dated the time of recharge to the Pleistocene when continental ice sheets covered much of the study area. The oldest radiocarbon ages coincided with the most depleted stable isotope samples, indicating groundwater from the Dakota aquifer in Cedar County was recharged from Pleistocene-age water, which is consistent with the findings by Gosselin and others (2001). One Dakota aquifer (noncalcium bicarbonate) subgroup well, LPN-1, which is within the Todd Valley (fig. 2), had a radiocarbon age of 30,500 years before present (table 7) with stable isotope values that were very isotopically depleted (table $5 B$ ). Groundwater sampled from LPN-1 likely had the same recharge history as wells in Cedar County farther to the north. Other samples from Dakota aquifer (noncalcium bicarbonate) subgroup wells, including D-A1 and LE-3 (fig. 1) with radiocarbon ages of 20,500 and 17,500 years before present (table 7), respectively, and isotopically depleted values (table $5 B$ ), also indicate Pleistocene-age recharge. Of the samples from the Dakota aquifer (noncalcium bicarbonate) subgroup, the three ${ }^{3} \mathrm{H}$ samples collected indicated that groundwater is considered premodern and likely to have recharged at least several hundred years ago (figs. 9 and 10, table 7).

Age tracer samples collected from the Dakota aquifer (calcium bicarbonate) subgroup indicate that nearly all samples have higher values for percent Modern Carbon compared to the Dakota aquifer (noncalcium bicarbonate) subgroup samples (table 7, fig. 7). Of the six ${ }^{14} \mathrm{C}$ samples from the Dakota aquifer (calcium bicarbonate) subgroup, all were considered modern (table 7). Of the five ${ }^{3} \mathrm{H}$ samples from the Dakota aquifer (calcium bicarbonate) subgroup, four were determined to be premodern and likely several hundred years old. The 


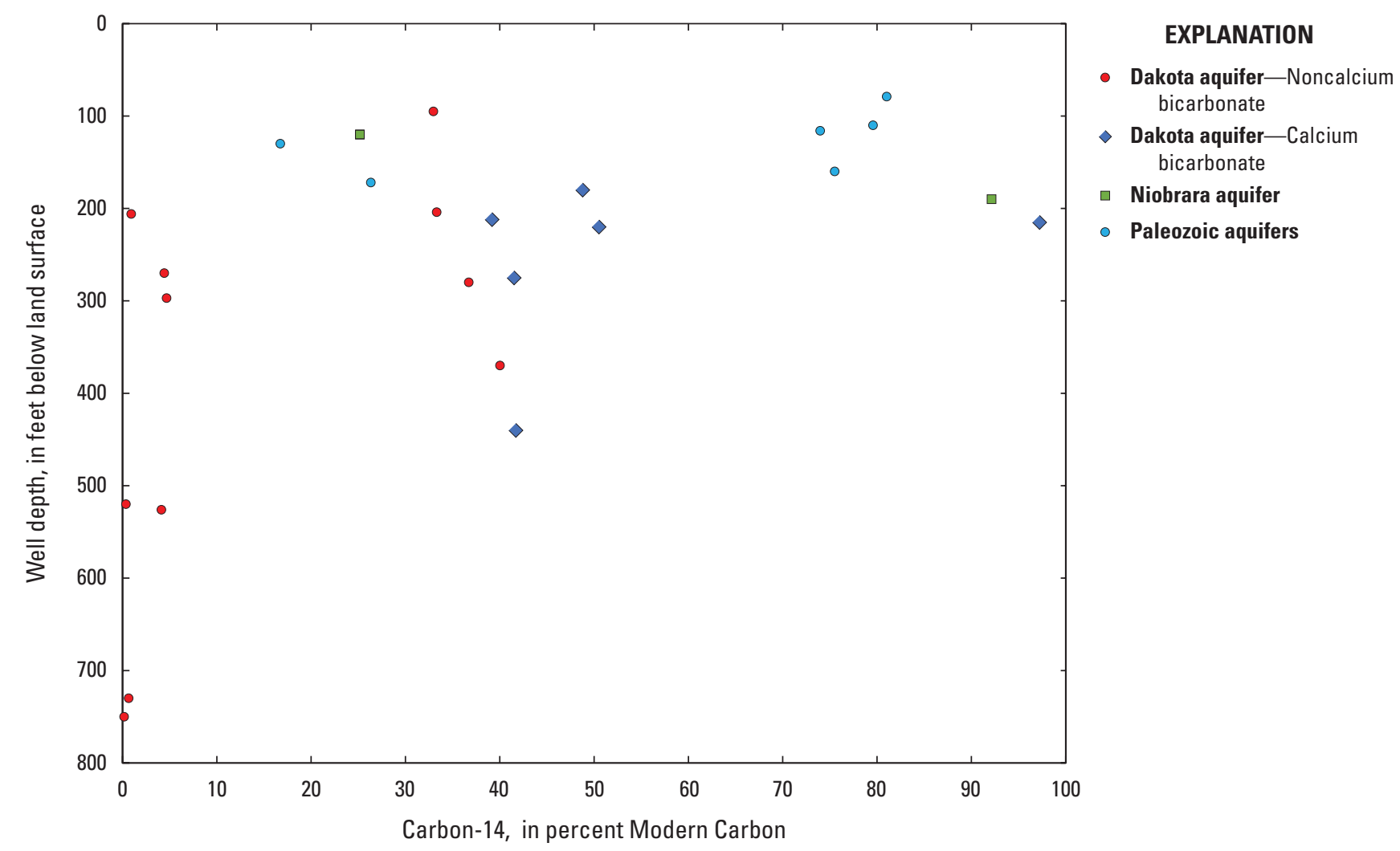

Figure 7. Concentrations of carbon-14 $\left({ }^{14} \mathrm{C}\right)$, in percent Modern Carbon, against well depth, eastern Nebraska, 2016-18.

fifth sample is a mixture of modern and premodern waters (table 7). One sample (PM D-1) was considered modern based on ${ }^{14} \mathrm{C}$ sampling and premodern based on ${ }^{3} \mathrm{H}$ sampling; however, the difference in ${ }^{3} \mathrm{H}$ concentration between the measured ${ }^{3} \mathrm{H}$ concentration and premodern/mixed threshold was within the reported error of the analysis (U.S. Geological Survey, 2020c). Three samples (D-SWSarpy1, D-Sp1, D-Sp2) from the Dakota aquifer (calcium bicarbonate) subgroup had nitrate concentrations above the background concentration of $2 \mathrm{mg} / \mathrm{L}$ (table 5B), indicating some post-1952 water in each sample. These three samples were characterized as mixed, modern, and premodern, respectively (table 7).

Two of the three samples (LE-5 and LE-6) collected from wells completed in the Niobrara aquifer are considered modern based on ${ }^{14} \mathrm{C}$ and (or) ${ }^{3} \mathrm{H}$ sampling. Unlike samples collected from the Dakota aquifer subgroups, these younger samples were characterized as being calcium sulfate water type, which is most likely the result of weathering of pyrite and gypsum in the overlying Pierre Shale (Divine and Sibray, 2017). One Niobrara aquifer sample, LC-4S, had a radiocarbon age of 3,400 years before present (fig. 8, table 7) and is characterized as having a calcium bicarbonate water type. LC-4S is within a monitoring well cluster with a Dakota aquifer (noncalcium bicarbonate) subgroup well (LC-4M), which had a radiocarbon age of 31,000 years before present (fig. 8, table 7). Well LC-4S was more isotopically depleted and had the lowest concentration of total dissolved solids compared to the other two samples from wells completed in the Niobrara aquifer (tables $5 A$ and $5 B$ ). It is possible that the sample collected from LC-4S is a mixture of older Dakota aquifer water and recent recharge, but it is difficult to make that interpretation with the data available.

Four of the six samples collected from wells completed in Paleozoic aquifers were characterized as modern based on ${ }^{14} \mathrm{C}$ results (table 7). These four modern samples had dissolved oxygen concentrations that ranged from 3 to $10.8 \mathrm{mg} / \mathrm{L}$ and nitrate concentrations that ranged from 1.89 to $16.8 \mathrm{mg} / \mathrm{L}$ (tables $5 A$ and $5 B$, figs. $5 A$ and $5 B$ ), indicating that the Paleozoic aquifers have been affected by agricultural activities in these locations. Stable isotope results for samples from wells completed in Paleozoic aquifers were the most isotopically enriched samples collected for this report and plot close to the LMWL (fig. 6), which indicates that recharge to Paleozoic aquifers is from local precipitation and appears to occur during warmer months. The radiocarbon ages for samples LPS-2 and N-5 were 13,000 and 7,000 years before present, respectively (table 7; fig. 8). Both of these samples had nitrate concentrations that were below the background concentration of $2 \mathrm{mg} / \mathrm{L}$ (table $5 B$ ); however, their stable isotope values plotted very close to the LMWL and to other samples determined to be modern, indicating that these samples are likely a mixture of modern recharge and older water (table $5 B$, fig. 6). Three ${ }^{3} \mathrm{H}$ samples collected from the Paleozoic aquifers indicated that two samples ( $\mathrm{N}-3$ and LPS-4) were determined 
Table 7. Calculated radiocarbon ages and tritium $\left({ }^{3} \mathrm{H}\right)$ age categories from sampled wells, eastern Nebraska, $2016-18$.

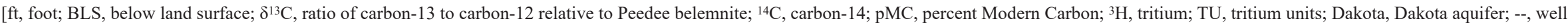

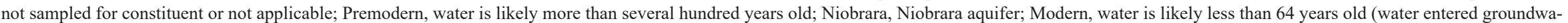
ter system after 1952); Paleozoic, Paleozoic aquifers; Mixed, water is likely a mixture of groundwater less than 64 years old and groundwater more than several hundred years old]

\begin{tabular}{|c|c|c|c|c|c|c|c|c|c|c|c|c|}
\hline Site number & Field name & $\begin{array}{c}\text { Well } \\
\text { depth } \\
\text { (ft BLS) }\end{array}$ & Aquifer sampled & $\begin{array}{c}\text { Date } \\
\text { sampled }\end{array}$ & $\begin{array}{c}\delta^{13} \mathrm{C} \\
\text { per mil }\end{array}$ & $\begin{array}{c}{ }^{14} \mathrm{C}, \\
\text { in } \\
\text { percent } \\
\text { modern }\end{array}$ & $\begin{array}{c}\text { Radiocarbon } \\
\text { age, }{ }^{14} \mathrm{C} \\
\text { (pMC) }\end{array}$ & $\begin{array}{c}{ }^{14} \mathrm{C} \text { apparent } \\
\text { age in years } \\
\text { before } \\
\text { present }\end{array}$ & $\begin{array}{c}{ }^{3} \mathrm{H} \\
\text { (TU) }\end{array}$ & $\begin{array}{c}\text { Premodern }{ }^{3} \mathrm{H} \\
\text { concentration } \\
\text { threshold } \\
\text { (TU) }\end{array}$ & $\begin{array}{l}\text { Modern }{ }^{3} \mathrm{H} \\
\text { concentration } \\
\text { threshold } \\
\text { (TU) }\end{array}$ & $\begin{array}{c}{ }^{3} \mathrm{H} \text { age } \\
\text { category }\end{array}$ \\
\hline 413912096462201 & LE-3 & 526 & $\begin{array}{l}\text { Dakota (non- } \\
\text { calcium } \\
\text { bicarbonate) }\end{array}$ & $8 / 24 / 2016$ & -9.27 & 4 & 4.1 & 17,500 & -- & -- & -- & -- \\
\hline 424611097185201 & $\begin{array}{l}\text { LC-6S } \\
\text { domestic }\end{array}$ & 95 & $\begin{array}{l}\text { Dakota (non- } \\
\text { calcium } \\
\text { bicarbonate) }\end{array}$ & $8 / 11 / 2016$ & -10.02 & 31.98 & 33.0 & 1,100 & -- & -- & -- & -- \\
\hline 423317097160901 & LC $-4 \mathrm{M}$ & 730 & $\begin{array}{l}\text { Dakota (non- } \\
\text { calcium } \\
\text { bicarbonate) }\end{array}$ & $8 / 10 / 2016$ & -7.82 & 0.64 & 0.7 & 31,000 & -- & -- & -- & -- \\
\hline 424713097170101 & LC-6M & 520 & $\begin{array}{l}\text { Dakota (non- } \\
\text { calcium } \\
\text { bicarbonate) }\end{array}$ & $8 / 9 / 2016$ & -7.03 & 0.35 & 0.4 & 35,000 & -- & -- & -- & -- \\
\hline 424713097170102 & LC-6D & 750 & $\begin{array}{l}\text { Dakota (non- } \\
\text { calcium } \\
\text { bicarbonate) }\end{array}$ & $8 / 9 / 2016$ & -7.2 & 0.17 & 0.2 & 41,000 & -- & -- & -- & -- \\
\hline 410002096551101 & LPS-5 & 162 & $\begin{array}{l}\text { Dakota (non- } \\
\text { calcium } \\
\text { bicarbonate) }\end{array}$ & $10 / 27 / 2016$ & -- & -- & -- & -- & 0.00 & 0.23 & 2.37 & $\begin{array}{l}\text { Pre- } \\
\quad \text { modern }\end{array}$ \\
\hline 411005096311701 & LPN-1 & 206 & $\begin{array}{l}\text { Dakota (non- } \\
\text { calcium } \\
\text { bicarbonate) }\end{array}$ & $4 / 11 / 2017$ & -9.95 & 0.9 & 0.9 & 30,500 & 0.03 & 0.22 & 2.24 & $\begin{array}{l}\text { Pre- } \\
\quad \text { modern }\end{array}$ \\
\hline 411845096211203 & D-Va3 & 204 & $\begin{array}{l}\text { Dakota (non- } \\
\text { calcium } \\
\text { bicarbonate) }\end{array}$ & $3 / 9 / 2018$ & -8.85 & 32.24 & 33.3 & $\begin{array}{l}\text { Modern } \\
\quad(\text { post-1950) }\end{array}$ & -- & -- & -- & -- \\
\hline 412758096222801 & $\mathrm{D}-\mathrm{A} 1$ & 297 & $\begin{array}{l}\text { Dakota (non- } \\
\text { calcium } \\
\text { bicarbonate) }\end{array}$ & $11 / 2 / 2016$ & -10.65 & 4.54 & 4.7 & 20,500 & 0.09 & 0.23 & 2.37 & $\begin{array}{l}\text { Pre- } \\
\quad \text { modern }\end{array}$ \\
\hline 421406096294901 & D-Th1 & 370 & $\begin{array}{l}\text { Dakota (non- } \\
\text { calcium } \\
\text { bicarbonate) }\end{array}$ & $10 / 14 / 2016$ & -9.18 & 38.76 & 40.0 & $\begin{array}{l}\text { Modern } \\
\quad(\text { post-1950) }\end{array}$ & -- & -- & -- & -- \\
\hline 422616096343801 & D-J1 & 470 & $\begin{array}{l}\text { Dakota (non- } \\
\text { calcium } \\
\text { bicarbonate) }\end{array}$ & $10 / 13 / 2016$ & -7.82 & 4.28 & 4.4 & 15,500 & -- & -- & -- & -- \\
\hline
\end{tabular}




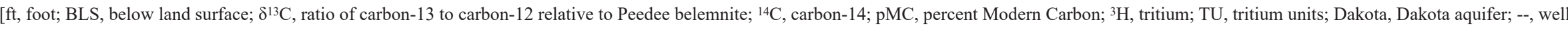

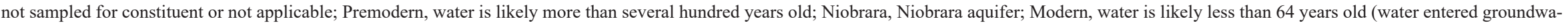
ter system after 1952); Paleozoic, Paleozoic aquifers; Mixed, water is likely a mixture of groundwater less than 64 years old and groundwater more than several hundred years old]

\begin{tabular}{|c|c|c|c|c|c|c|c|c|c|c|c|c|}
\hline Site number & Field name & $\begin{array}{c}\text { Well } \\
\text { depth } \\
\text { (ft BLS) }\end{array}$ & Aquifer sampled & $\begin{array}{c}\text { Date } \\
\text { sampled }\end{array}$ & $\begin{array}{c}\delta^{13} \mathrm{C}, \\
\text { per mil }\end{array}$ & $\begin{array}{l}{ }^{14} \mathrm{C} \text {, in } \\
\text { percent } \\
\text { modern }\end{array}$ & $\begin{array}{c}\text { Radiocarbon } \\
\text { age, }{ }^{14} \mathrm{C} \\
\text { (pMC) }\end{array}$ & $\begin{array}{l}{ }^{14} \mathrm{C} \text { apparent } \\
\text { age in years } \\
\text { before present }\end{array}$ & $\begin{array}{c}{ }^{3} \mathrm{H} \\
\text { (TU) }\end{array}$ & $\begin{array}{c}\text { Premodern }{ }^{3} \mathrm{H} \\
\text { concentration } \\
\text { threshold } \\
\text { (TU) }\end{array}$ & $\begin{array}{c}\text { Modern }{ }^{3} \mathrm{H} \\
\text { concentration } \\
\text { threshold } \\
\text { (TU) }\end{array}$ & $\begin{array}{c}{ }^{3} \mathrm{H} \text { age } \\
\text { category }\end{array}$ \\
\hline 422616096343802 & D-J2 & 280 & $\begin{array}{l}\text { Dakota (non- } \\
\text { calcium } \\
\text { bicarbonate) }\end{array}$ & $10 / 13 / 2016$ & -9.44 & 35.57 & 36.7 & $\begin{array}{l}\text { Modern } \\
\quad \text { (post-1950) }\end{array}$ & -- & -- & -- & -- \\
\hline 413618096322901 & LE-1 & 181 & $\begin{array}{c}\text { Dakota (calcium } \\
\text { bicarbonate) }\end{array}$ & $8 / 25 / 2016$ & -- & -- & -- & -- & 0.22 & 0.23 & 2.37 & $\begin{array}{l}\text { Pre- } \\
\text { modern }\end{array}$ \\
\hline 413639096274901 & LE-2 & 220 & $\begin{array}{c}\text { Dakota (calcium } \\
\text { bicarbonate) }\end{array}$ & $8 / 25 / 2016$ & -8.21 & 48.82 & 50.5 & $\begin{array}{l}\text { Modern } \\
\quad \text { (post-1950) }\end{array}$ & -- & -- & -- & -- \\
\hline 413828096465801 & LE-4 & 239 & $\begin{array}{c}\text { Dakota (calcium } \\
\text { bicarbonate) }\end{array}$ & $8 / 24 / 2016$ & -- & -- & -- & -- & 0.16 & 0.23 & 2.37 & $\begin{array}{l}\text { Pre- } \\
\text { modern }\end{array}$ \\
\hline 421730096390001 & PM D-1 & 440 & $\begin{array}{c}\text { Dakota (calcium } \\
\text { bicarbonate) }\end{array}$ & $8 / 11 / 2016$ & -9.36 & 40.39 & 41.7 & $\begin{array}{l}\text { Modern } \\
\quad \text { (post-1950) }\end{array}$ & 0.16 & 0.23 & 2.37 & $\begin{array}{l}\text { Pre- } \\
\text { modern }\end{array}$ \\
\hline 410335096150101 & D-SWSarpy1 & 117 & $\begin{array}{c}\text { Dakota (calcium } \\
\text { bicarbonate) }\end{array}$ & $10 / 3 / 2016$ & -- & -- & -- & -- & 0.34 & 0.23 & 2.37 & Mixed \\
\hline 410613096071101 & D-Sp1 & 215 & $\begin{array}{c}\text { Dakota (calcium } \\
\text { bicarbonate) }\end{array}$ & $9 / 28 / 2016$ & -7.55 & 93.83 & 97.2 & $\begin{array}{l}\text { Modern } \\
\quad \text { (post-1950) }\end{array}$ & -- & -- & -- & -- \\
\hline 410613096071102 & D-Sp2 & 125 & $\begin{array}{c}\text { Dakota (calcium } \\
\text { bicarbonate) }\end{array}$ & $9 / 28 / 2016$ & -- & -- & -- & -- & 0.03 & 0.23 & 2.37 & $\begin{array}{l}\text { Pre- } \\
\text { modern }\end{array}$ \\
\hline 415958096152201 & D-D1 & 180 & $\begin{array}{c}\text { Dakota (calcium } \\
\text { bicarbonate) }\end{array}$ & $6 / 20 / 2018$ & -8.86 & 47.21 & 48.8 & $\begin{array}{l}\text { Modern } \\
\quad \text { (post-1950) }\end{array}$ & -- & -- & -- & -- \\
\hline 421406096294902 & D-Th2 & 275 & $\begin{array}{c}\text { Dakota (calcium } \\
\text { bicarbonate) }\end{array}$ & $10 / 14 / 2016$ & -9.3 & 40.2 & 41.5 & $\begin{array}{l}\text { Modern } \\
\quad \text { (post-1950) }\end{array}$ & -- & -- & -- & -- \\
\hline 405921096535101 & LPS -3 & 212 & $\begin{array}{c}\text { Dakota (calcium } \\
\text { bicarbonate) }\end{array}$ & $11 / 10 / 2016$ & -9.61 & 37.97 & 39.2 & $\begin{array}{l}\text { Modern } \\
\quad \text { (post-1950) }\end{array}$ & -- & -- & -- & -- \\
\hline 423317097161001 & $\mathrm{LC}-4 \mathrm{~S}$ & 120 & Niobrara & $8 / 10 / 2016$ & -10.09 & 24.41 & 25.2 & 3,400 & -- & -- & -- & -- \\
\hline 422344097120801 & LE-5 & 157 & Niobrara & $8 / 23 / 2016$ & -- & -- & -- & -- & 3.29 & 0.23 & 2.37 & Modern \\
\hline 422409097124601 & LE-6 & 180 & Niobrara & $8 / 23 / 2016$ & -8.57 & 89.11 & 92.1 & $\begin{array}{l}\text { Modern } \\
\quad(\text { post-1950) }\end{array}$ & 2.70 & 0.23 & 2.37 & Modern \\
\hline 405139096194801 & LPS-1 & 116 & Paleozoic & $10 / 6 / 2016$ & -6.54 & 71.25 & 74.0 & $\begin{array}{l}\text { Modern } \\
\quad \text { (post-1950) }\end{array}$ & 0.22 & 0.19 & 1.97 & Mixed \\
\hline 405213096205001 & LPS-2 & 130 & Paleozoic & $10 / 6 / 2016$ & -14.07 & 16.36 & 16.7 & 13,000 & -- & -- & -- & -- \\
\hline 402313095512401 & $\mathrm{~N}-3$ & 160 & Paleozoic & $10 / 5 / 2016$ & -6.88 & 72.78 & 75.5 & $\begin{array}{l}\text { Modern } \\
\quad \text { (post-1950) }\end{array}$ & 3.95 & 0.19 & 1.97 & Modern \\
\hline
\end{tabular}


Table 7. Calculated radiocarbon ages and tritium $\left({ }^{3} \mathrm{H}\right)$ age categories from sampled wells, eastern Nebraska, 2016-18.-Continued

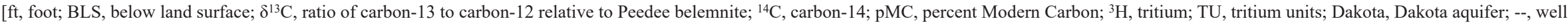

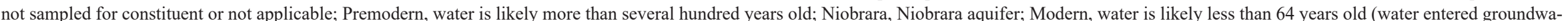
ter system after 1952); Paleozoic, Paleozoic aquifers; Mixed, water is likely a mixture of groundwater less than 64 years old and groundwater more than several hundred years old]

\begin{tabular}{|c|c|c|c|c|c|c|c|c|c|c|c|c|}
\hline Site number & Field name & $\begin{array}{c}\text { Well } \\
\text { depth } \\
\text { (ft BLS) }\end{array}$ & Aquifer sampled & $\begin{array}{c}\text { Date } \\
\text { sampled }\end{array}$ & $\begin{array}{c}\delta^{13} \mathrm{C} \\
\text { per mil }\end{array}$ & $\begin{array}{l}{ }^{14} \mathrm{C} \text {, in } \\
\text { percent } \\
\text { modern }\end{array}$ & $\begin{array}{l}\text { Radiocarbon } \\
\text { age, }{ }^{14} \mathrm{C} \\
\text { (pMC) }\end{array}$ & $\begin{array}{l}{ }^{14} \mathrm{C} \text { apparent } \\
\text { age in years } \\
\text { before present }\end{array}$ & $\begin{array}{c}{ }^{3} \mathrm{H} \\
\text { (TU) }\end{array}$ & $\begin{array}{c}\text { Premodern }{ }^{3} \mathrm{H} \\
\text { concentration } \\
\text { threshold } \\
\text { (TU) }\end{array}$ & $\begin{array}{l}\text { Modern }{ }^{3} \mathrm{H} \\
\text { concentration } \\
\text { threshold } \\
\text { (TU) }\end{array}$ & $\begin{array}{c}{ }^{3} \mathrm{H} \text { age } \\
\text { category }\end{array}$ \\
\hline 401759096003301 & $\mathrm{~N}-5$ & 172 & Paleozoic & $11 / 8 / 2016$ & -12.5 & 25.67 & 26.3 & 7,000 & -- & -- & -- & -- \\
\hline 404950096205501 & LPS -4 & 110 & Paleozoic & $10 / 5 / 2016$ & -6.96 & 76.71 & 79.6 & $\begin{array}{l}\text { Modern } \\
\quad(\text { post-1950) }\end{array}$ & 3.54 & 0.19 & 1.97 & Modern \\
\hline 401819095493701 & $\mathrm{~N}-6$ & 79 & Paleozoic & $11 / 8 / 2016$ & -7.53 & 78.2 & 81.0 & $\begin{array}{l}\text { Modern } \\
\quad(\text { post-1950) }\end{array}$ & -- & -- & -- & -- \\
\hline
\end{tabular}




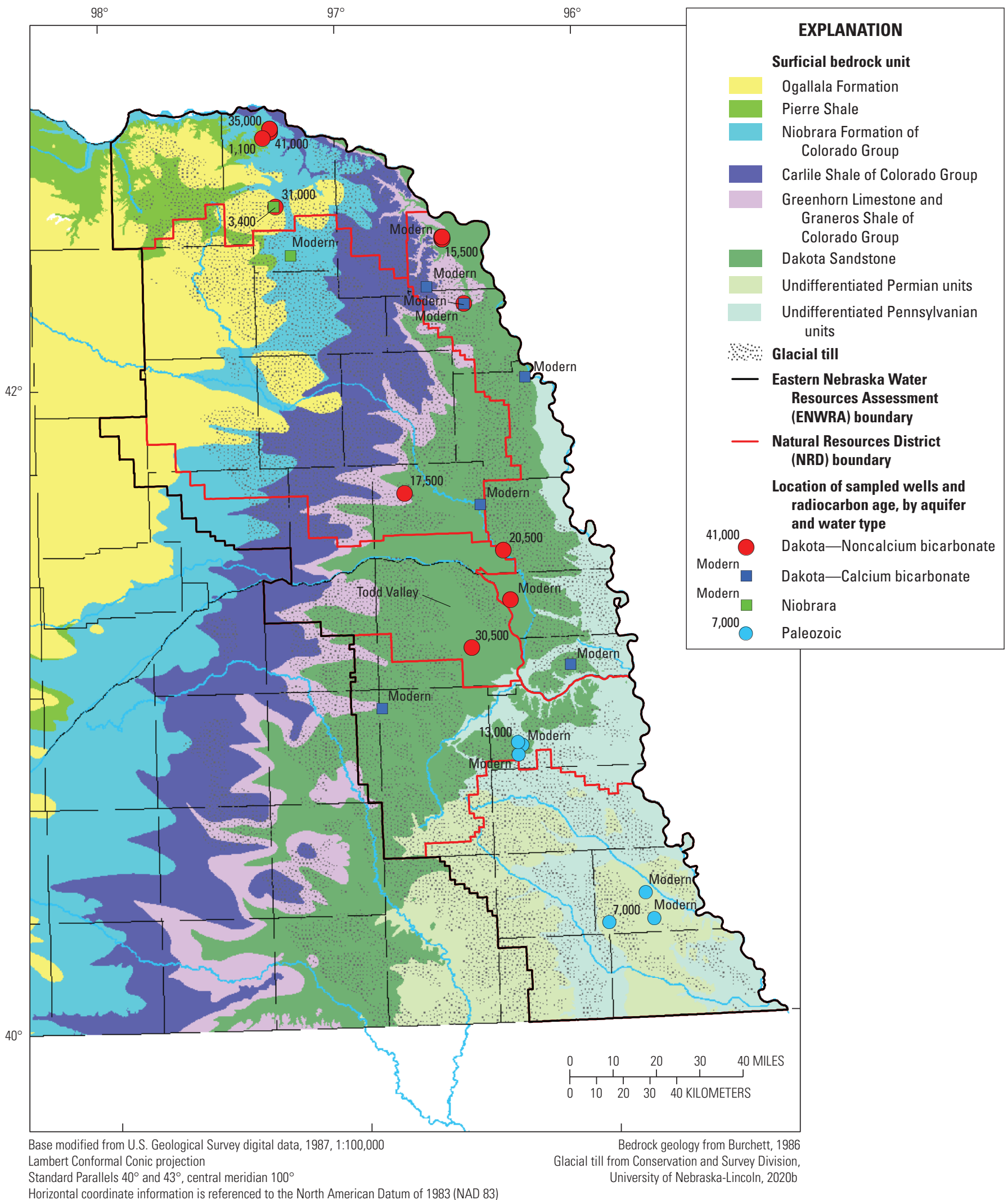

Figure 8. Radiocarbon ages, in years before present, from sampled wells, eastern Nebraska, 2016-18. 


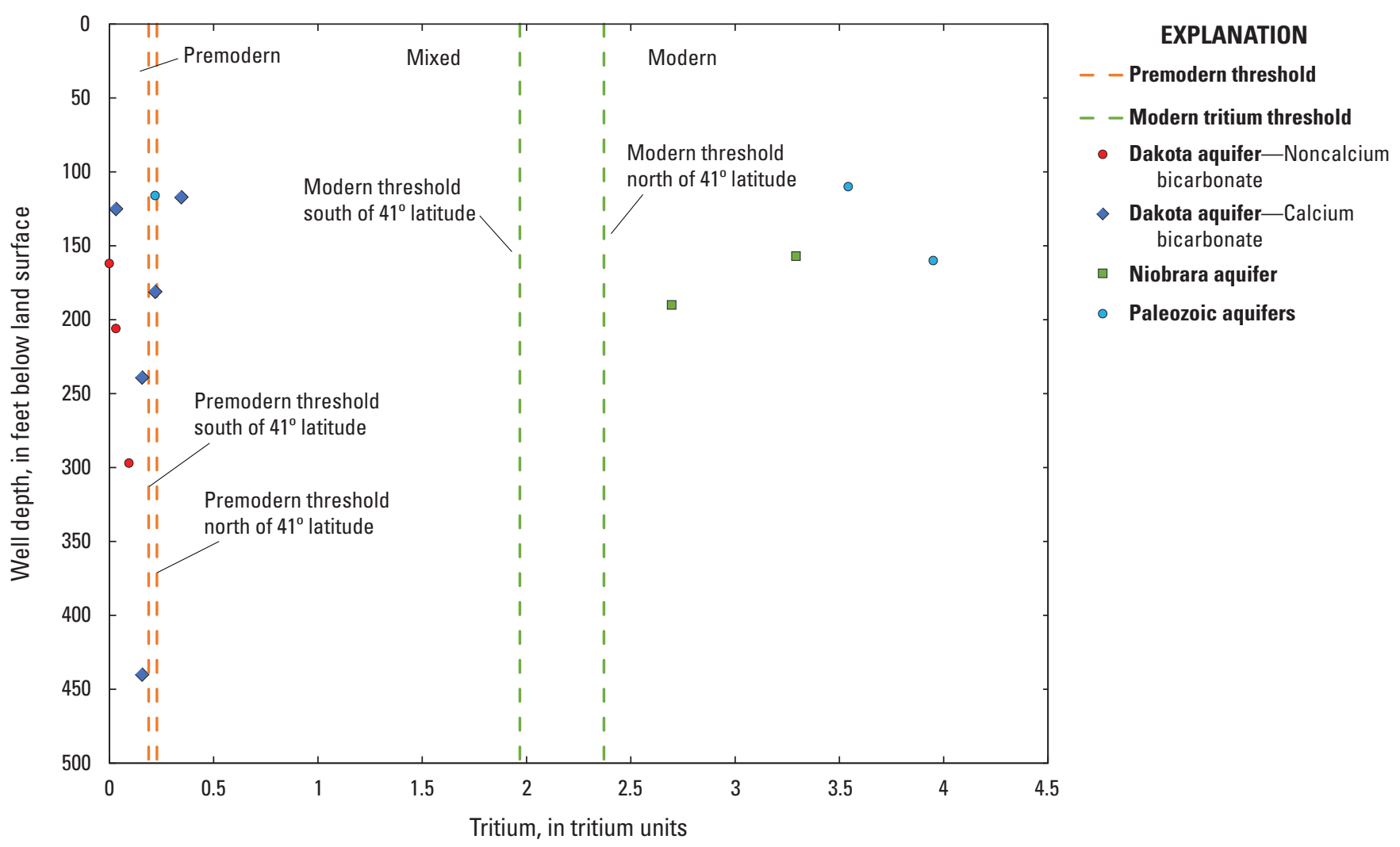

Figure 9. Concentrations of tritium $\left({ }^{3} \mathrm{H}\right)$ against well depth, eastern Nebraska, 2016-18.

to be modern with elevated nitrate concentrations and one sample (LPS-1) was mixed with nitrate concentration below $2 \mathrm{mg} / \mathrm{L}$ (tables $5 B$ and 7). Based on the six samples collected from the Paleozoic aquifers, water type did not appear to be diagnostic for determining the age and recharge history of groundwater in these aquifers.

\section{Ground water Management Implications}

The results of this study indicate that the dominant water type determined from samples collected from the Dakota aquifer are diagnostic for assessing the quality, recharge source, and age of groundwater. Groundwater samples collected from the Dakota aquifer, where calcium bicarbonate was the dominant water type, show very different geochemical characteristics from samples with other water types. Calcium bicarbonate dominant samples from the Dakota aquifer were characterized as modern or mixed using radiocarbon results, indicating that in these areas, groundwater is unconfined and is recharged by precipitation and (or) surface water (table 7, figs. 7 and 8).

Stable isotope ratios of calcium bicarbonate dominant samples from the Dakota aquifer were more isotopically enriched compared to other water types and were similar to modern precipitation values (tables $5 A$ and $5 B$, fig. 6 ). If groundwater extraction rates exceed recharge rates, total dissolved solid concentrations may increase as a result of upwelling of groundwater from deeper units, which can adversely affect groundwater quality. Concentrations of nitrate for calcium bicarbonate dominant samples from the Dakota aquifer were generally near or below background, but some wells indicated effects from agricultural activities (fig. $5 B$ ). It should be noted that seven samples were considered anoxic (dissolved oxygen less than $0.5 \mathrm{mg} / \mathrm{L}$ ) and could indicate that denitrification is reducing nitrate concentrations in groundwater. Sampling results presented in this report indicate water quality in the Dakota aquifer with a calcium bicarbonate water type is good, but that the groundwater may be vulnerable to surface contamination. Future groundwater sampling plans could focus on understanding how groundwater quality in the Dakota aquifer with a calcium bicarbonate water type changes in the future.

In contrast, groundwater sampled from the Dakota aquifer, having a dominant water type other than calcium bicarbonate, generally has low dissolved oxygen and nitrate concentrations, and higher concentrations of total dissolved solids and trace elements, including iron and strontium. The geochemical characteristics of these samples indicated confining conditions and limited groundwater recharge from local precipitation. Of the 12 wells sampled from the Dakota aquifer where calcium bicarbonate was not the dominant water type, only 2 were characterized as modern. Similar to what Gosselin and others (2001) reported for Cedar County, apparent groundwater age estimated from ${ }^{14} \mathrm{C}$ sampling dates groundwater recharge to the Dakota aquifer to Pleistocene time. Depleted stable isotope 


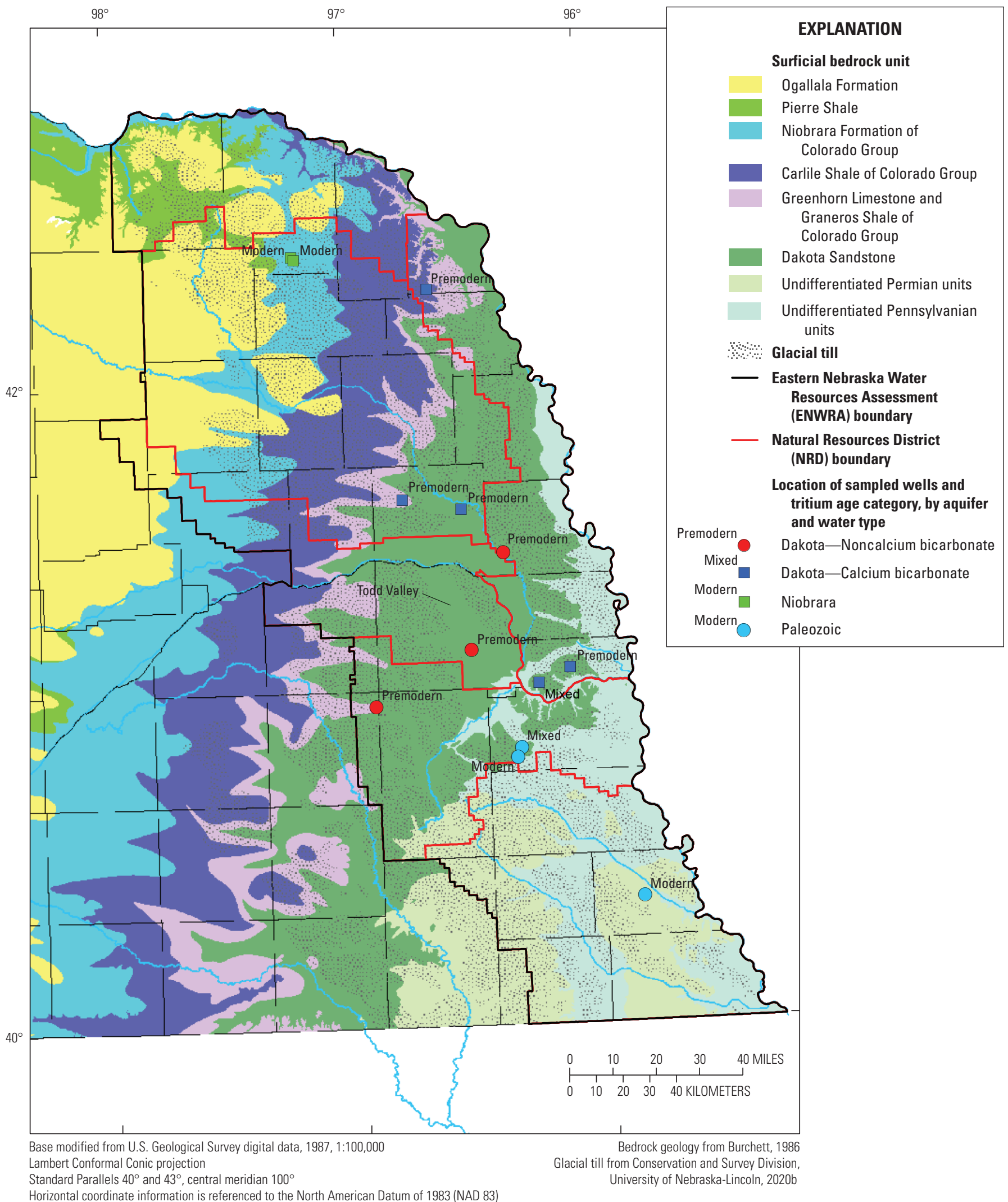

Figure 10. Tritium ( $\left.{ }^{3} \mathrm{H}\right)$ age category from sampled wells, eastern Nebraska, 2016-18. 
results from these samples indicate recharge occurred during a colder climate. Other samples collected in wells completed in sandstone below layers of shale, mudstone, or clay within the Dakota aquifer (Dakota, Washington, Saunders, and Douglas Counties for this report) show similar geochemical and age characteristics. Groundwater in these areas is not easily recharged from precipitation or surface water. Future groundwater-level monitoring could provide information to evaluate whether groundwater supplies remain sufficient to meet future domestic and irrigation needs. Sampling results from the Dakota aquifer, having a dominant water type other than calcium bicarbonate, indicate that groundwater is not vulnerable to surface contamination; however, groundwaterquality issues include elevated concentrations of total dissolved solids and trace elements.

For the Niobrara aquifer and Paleozoic aquifers, the dominant water type was not a diagnostic indicator of recharge source, age, and groundwater quality as it was with the Dakota aquifer. Most likely this is because the host aquifer was dominated by calcium-carbonate-rich rocks, and prolonged rock-water interaction would result in higher concentrations of these major ions; however, relatively few samples were collected from these aquifers to be able to confirm this interpretation. Samples collected from wells completed in the Niobrara aquifer (2 wells) and Paleozoic aquifers (1 well) and characterized as calcium sulfate water type have statistically significantly higher concentrations of total dissolved solids compared to other samples from the Niobrara aquifer and Paleozoic aquifers characterized as calcium bicarbonate. Given that six of the nine of samples collected from the Niobrara and Paleozoic aquifers indicated modern recharge, these secondary bedrock aquifers are reliant on recharge from precipitation to sustain groundwater levels and may be vulnerable to a multiyear drought. Divine and Sibray (2017) state that yields to wells completed in the Niobrara are dependent on the presence of bedding planes, and Tanner and Steele (1991) noted that well yields in Paleozoic aquifers are dependent on fracturing and secondary porosity. It can be inferred that these units offer little storage and that the Niobrara and Paleozoic aquifers are susceptible to overpumping or a multiyear drought. Samples collected from wells completed in Paleozoic aquifers were the most isotopically enriched, isotopically similar to modern precipitation, and had the highest concentrations of nitrate. Sampling indicated that groundwater in Paleozoic and Niobrara aquifers is affected by agricultural activities and future groundwater sampling would be needed to characterize groundwater-quality changes with time.

\section{Summary}

The Eastern Nebraska Water Resources Assessment (ENWRA) project was initiated in 2006 to assist water managers by developing a hydrogeologic framework and water budget for the portion of eastern Nebraska overlain by glacial deposits. The study area covers more than 8,000,000 acres across the Lewis and Clark, Lower Elkhorn, Lower Platte North, Lower Platte South, Nemaha, and Papio-Missouri River Natural Resources Districts (NRDs) and roughly coincides with the extent of glacial till within Nebraska. Municipal, irrigation, and domestic groundwater needs are met from alluvial, buried paleovalley and the High Plains aquifer (where present) and generally, bedrock aquifers are considered a secondary water source; however, in some areas, such as parts of Sarpy and Nemaha Counties, bedrock aquifers are the only source of water within glaciated upland areas. Within eastern Nebraska, population growth has led to increased development of groundwater resources for domestic and municipal needs. Groundwater pumping for irrigation during recent droughts $(2000-6 ; 2012)$ have reduced streamflows and strained drinking-water supplies for some towns and cities.

In response to some of these concerns, water resource managers have been evaluating the use of secondary aquifers to meet future drinking-water needs. To improve the understanding of the quality, geochemistry, and age of groundwater from selected bedrock aquifers in the ENWRA area, the U.S. Geological Survey, in cooperation with the ENWRA group, which includes the Lewis and Clark, Lower Elkhorn, Lower Platte North, Lower Platte South, Nemaha, and PapioMissouri River NRDs, designed a study to sample 31 wells and analyze samples for major ions, physical properties, nutrients, stable isotopes, and selected age tracers. Of the 31 samples collected for this report, 22 samples were collected from wells completed in the Dakota aquifer contained in the Dakota Sandstone, 3 from wells completed in the Niobrara aquifer contained in the Niobrara Formation of Colorado Group, and 6 from wells completed in Paleozoic aquifer contained in undifferentiated Paleozoic-age units. The proportion of samples used in this study roughly reflects the proportion of water use of these bedrock aquifers, with the Dakota aquifer being the most widely used of the aquifers sampled.

The results of this study indicate that major ion data collected from the Dakota aquifer can be used for assessing the quality, recharge source, and age of groundwater. Calcium bicarbonate dominant samples were characterized as modern or mixed, indicating that in these areas, groundwater is unconfined and is recharged by precipitation and (or) surface water. Stable isotope ratios of calcium bicarbonate dominant samples were more isotopically enriched compared to other water types in the Dakota aquifer and were similar to modern precipitation values. If groundwater extraction rates from the Dakota aquifer exceed recharge rates, total dissolved solid concentrations may increase as a result of upwelling of groundwater from deeper units, which can adversely affect groundwater quality. Sampling results presented in this report indicate water quality from the Dakota aquifer with a calcium bicarbonate water type is good, but that groundwater may be vulnerable to surface contamination. Future groundwater sampling plans for the Dakota aquifer with a calcium bicarbonate water type could focus on understanding how groundwater quality changes in the future. 
In contrast, groundwater sampled from the Dakota aquifer, having a dominant water type other than calcium bicarbonate, generally has low dissolved oxygen and nitrate concentrations, and higher concentrations of total dissolved solids and trace elements, including iron and strontium. The geochemical characteristics of these samples indicated confining conditions and groundwater recharge from local precipitation were limited. Apparent groundwater age estimated from ${ }^{14} \mathrm{C}$ (or radiocarbon) sampling dates groundwater recharge to the Dakota aquifer with noncalcium bicarbonate water type during Pleistocene time. Depleted stable isotopes indicate recharge occurred during a colder climate. Other samples collected in wells completed in sandstone below layers of shale, mudstone, or clay in the upper Dakota aquifer (Dakota, Washington, Saunders, and Douglas Counties for this report) show similar geochemical and age characteristics. Groundwater under confined conditions is not easily recharged from precipitation or surface water. Future groundwater-level monitoring of the Dakota aquifer with noncalcium bicarbonate water type could provide information to evaluate whether groundwater supplies remain sufficient to meet future domestic and irrigation needs. Sampling results indicate that groundwater from the Dakota aquifer with noncalcium bicarbonate water type is not vulnerable to surface contamination; however, groundwater-quality issues include elevated concentrations of total dissolved solids and trace elements.

For the Niobrara aquifer and Paleozoic aquifers, the dominant water type was not a diagnostic indicator of recharge source, age, and groundwater quality as with the Dakota aquifer. Most likely this is because the host formation was dominated by calcium-carbonate-rich rocks, and prolonged rock-water interaction would result in higher concentrations of these major ions; however, relatively few samples were collected from these aquifers to be able to confirm this interpretation. Samples collected from wells completed in the Niobrara aquifer and Paleozoic aquifers and characterized as calcium sulfate water type have statistically significantly higher specific conductance, and by inference, total dissolved solids compared to other samples from the Niobrara aquifer and Paleozoic aquifers characterized as calcium bicarbonate. Given that six of the nine of samples collected from the Niobrara and Paleozoic aquifers indicated modern recharge, these secondary bedrock aquifers are reliant on precipitation to sustain groundwater levels and may be vulnerable to a multiyear drought. Yields to wells completed in the Niobrara aquifer are dependent on the presence of bedding planes and yields in Paleozoic aquifers are dependent on fracturing and secondary porosity. It can be inferred that these units offer little storage and that the Niobrara and Paleozoic aquifers are susceptible to overpumping or a multiyear drought. Samples collected from wells completed in Paleozoic aquifers were the most isotopically enriched, isotopically similar to modern precipitation, and had the highest concentrations of nitrate. Sampling indicated that groundwater in Paleozoic and Niobrara aquifers is affected by agricultural activities and future groundwater sampling would be beneficial to characterize groundwater-quality changes with time.

\section{References Cited}

Burchett, R.R., 1986, Geologic bedrock of Nebraska: University of Nebraska Conservation and Survey Division Geologic Maps and Charts 1, scale 1:1,000,000.

Cannia, J.C., Abraham, J.D., and Asch, T.H., 2017, Hydrogeologic framework of selected areas in the Lower Elkhorn Natural Resources District: Aqua Geo Frameworks, 125 p.

Carney, C.P., Abraham, J.D., Cannia, J.C., and Steele, G.V., 2015a, Final report on airborne electromagnetic geophysical surveys and hydrogeologic framework development for the Eastern Nebraska Water Resources Assessment-Volume I. Including Lewis \& Clark, Lower Elkhorn, and the PapioMissouri Natural Resources District: Exploration Resources International, 152 p., accessed May 14, 2019, at http://www. enwra.org/aem\%20data\%20download.html.

Carney, C.P., Abraham, J.D., Cannia, J.C., and Steele, G.V., 2015b, Final report on airborne electromagnetic geophysical surveys and hydrogeologic framework development for the Eastern Nebraska Water Resources Assessment-Volume II. Including Lower Platte North, Lower Platte South, and Nemaha Natural Resources District: Exploration Resources International, 180 p., accessed June 2019 at http://www. enwra.org/aem\%20data\%20download.html.

Center for Advanced Land Management Information Technologies, 2007, 2005 Nebraska land use patterns: Lincoln, Nebr., University of Nebraska-Lincoln, geospatial data, accessed May 14, 2019, at https://dnr.nebraska.gov/ sites/dnr.nebraska.gov/files/doc/data/land-use/landuse.zip.

Clark, I.D., and Fritz, P., 1997, Environmental isotopes in hydrogeology: New York, Lewis Publishers, 328 p.

Condra, G.E., and Reed, E.C., 1943, The geological section of Nebraska: Lincoln, Nebr., University of Nebraska-Lincoln, Conservation and Survey Division, Nebraska Geological Survey Bulletin, v. 14, p. 82.

Conservation and Survey Division, University of NebraskaLincoln, 2020a, Nebraska statewide test-hole database: University of Nebraska-Lincoln, Institute of Agriculture and Natural Resources, digital data, accessed May 8, 2019, at http://snr.unl.edu/csd/geology/testholes.aspx.

Conservation and Survey Division, University of NebraskaLincoln, 2020b, Till — Geology related GIS data: University of Nebraska-Lincoln, Institute of Agriculture and Natural Resources, digital data, accessed May 14, 2019, at http://snr.unl.edu/csd-esic/download/geographygis/utm/ till_utm.zip. 
Conservation and Survey Division, University of NebraskaLincoln, 2020c, Topographic regions, 2019: University of Nebraska-Lincoln, Institute of Agriculture and Natural Resources, digital data, accessed May 14, 2019, at http://snr.unl.edu/csd-esic/download/geographygis/utm/ toporeg_utm.zip.

Coplen, T.B., and Kendall, C., 2000, Stable hydrogen and oxygen isotope ratios for selected sites of the U.S. Geological Survey's NASQAN and benchmark surface-water networks: U.S. Geological Survey Open-File Report 2000-160, 490 p., accessed June 23, 2020, at https://doi.org/ 10.3133/ofr00160.

Craig, H., 1961, Isotopic variations in meteoric waters: Science, v. 133, no. 3465, p. 1702-1703. [Also available at https://doi.org/10.1126/science.133.3465.1702.]

Cunningham, W.L., and Schalk, C.W., comps., 2011, Groundwater technical procedures of the U.S. Geological Survey: U.S. Geological Survey Techniques and Methods, book 1, chap. A1, 151 p., accessed May 4, 2020, at https://doi.org/10.3133/tm1A1.

Dieter, C.A., Linsey, K.S., Caldwell, R.R., Harris, M.A., Ivahnenko, T.I., Lovelace, J.K., Maupin, M.A., and Barber, N.L., 2018, Estimated use of water in the United States county-level data for 2015 (ver. 2.0, June 2018): U.S. Geological Survey data release, accessed June 23, 2020, at https://doi.org/10.5066/F7TB15V5.

Divine, D.P., 2014, The groundwater atlas of Lancaster County, Nebraska: Conservation and Survey Division University of Nebraska-Lincoln, Resource Atlas 7, 39 p., accessed April 13, 2020, at https://digitalcommons.unl.edu/ conservationsurvey/39/.

Divine, D.P., 2015, The Groundwater Atlas of Saunders County, Nebraska: Conservation and Survey Division University of Nebraska-Lincoln, Resource Atlas 9, 37 p., accessed April 13, 2020, at https://digitalcommons.unl.edu/ conservationsurvey/40/.

Divine, D.P., Joeckel, R.M., Korus, J.T., Hanson, P.R., and Olafsen-Lackey, S., 2009, Eastern Nebraska Water Resources Assessment (ENWRA) - Introduction to a hydrogeological study: University of Nebraska-Lincoln Conservation and Survey Division Bulletin 1, accessed February 19, 2020, at http://enwra.org/media/enwra overview.pdf.

Divine, D.P., and Sibray, S.S., 2017, An overview of secondary aquifers in Nebraska: University of Nebraska-Lincoln Conservation and Survey Division Educational Circular no. 26, 40 p., accessed April 13, 2020, at https://dig italcommons.unl.edu/conservationsurvey/138/.
Druliner, A.D., and Mason, J.P., 2000, Hydrogeology and water quality of five principal aquifers in the Lower Platte South Natural Resources District, eastern Nebraska, 1994: Water-Resources Investigations Report 2000-4155, 45 p., accessed April 9, 2020, at https://doi.org/10.3133/ wri004155.

Engberg, R.A., 1984, Appraisal of data for ground-water quality in Nebraska: U.S. Geological Survey WaterSupply Paper 2245, 54 p., accessed April 14, 2020, at https://doi.org/10.3133/wsp2245.

Engberg, R.A. and Druliner, A.D., 1987, Nebraska groundwater quality: U.S. Geological Survey Open-File Report 87-0737, 9 p. accessed April 11, 2020, at https://doi.org/ 10.3133/ofr87737.

Fenneman, N.M., and Johnson, D.W., 1946, The physical divisions of the United States: U.S. Geological Survey, 1 plate, accessed April 10, 2020, at https://water.usgs.gov/GIS/dsdl/ physio_shp.zip.

Fishman, M.J., ed., 1993, v. 93-125. Methods of analysis by the U.S. Geological Survey National Water Quality Laboratory-Determination of inorganic and organic constituents in water and fluvial sediments, U.S. Geological Survey Open-File Report, 217 p. [Also available at https://doi.org/10.3133/ofr93125.]

Fishman, M.J., and Friedman, L.C., 1989, Methods for determination of inorganic substances in water and fluvial sediments: U.S. Geological Survey Techniques of WaterResources Investigations, book 5, chap. A1, 545 p. [Also available at https://doi.org/10.3133/twri05A1.]

Fontes, J.-Ch., and Garnier, J.-M., 1979, Determination of the initial ${ }^{14} \mathrm{C}$ activity of the total dissolved carbon-A review of the existing models and a new approach: Water Resources Research, v. 15, no. 2, p. 399-413. [Also available at https://doi.org/10.1029/WR015i002p00399.]

Garbarino, J.R., 1999, Methods of Analysis by the U.S. Geological Survey National Water Quality Laboratory-Determination of dissolved arsenic, boron, lithium, selenium, strontium, thallium, and vanadium using inductively coupled plasma-mass spectrometry: U.S. Geological Survey Open-File Report 99-093, 31 p. [Also available at https://doi.org/10.3133/ofr9993.]

Garbarino, J.R., and Damrau, D.L., 2001, Methods of Analysis by the U.S. Geological Survey National Water Quality Laboratory-Determination of organic plus inorganic mercury in filtered and unfiltered natural water with cold vapor-atomic fluorescence spectrometry: U.S. Geological Survey Water-Resources Investigations Report 01-4132, 16 p. [Also available at https://doi.org/10.3133/wri014132.] 
Garbarino, J.R., Kanagy, L.K., and Cree, M.E., 2006, Determination of elements in natural-water, biota, sediment, and soil samples using collision/reaction cell inductively coupled plasma-mass spectrometry: U.S. Geological Survey Techniques and Methods, book 5, chap. B1, 88 p. [Also available at https://doi.org/10.3133/tm5B1.]

Gosselin, D.C., Harvey, F.E., and Frost, C.D., 2001, Geochemical evolution of ground water in the Great Plains Dakota Aquifer of Nebraska-Implications for the management of a regional aquifer system: Ground Water, v. 39, no. 1, p. 98-108. [Also available at https://doi.org/10.1111/ j.1745-6584.2001.tb00355.x.]

Green, C.T., and Bekins, B.A., 2010, Sustainability of natural attenuation of nitrate in agricultural aquifers: U.S. Geological Survey Fact Sheet 2010-3077, 4 p. [Also available at https://doi.org/10.3133/fs20103077.]

Gutentag, E.D., Heimes, F.J., Krothe, N.C., Luckey, R.R., and Weeks, J.B., 1984, Geohydrology of the High Plains aquifer in parts of Colorado, Nebraska, New Mexico, Oklahoma, South Dakota, Texas, and Wyoming: U.S. Geological Survey Professional Paper 1400-B, 63 p. [Also available at https://doi.org/10.3133/pp1400B.]

Han, L.-F., and Plummer, L.N., 2013, Revision of Fontes $\&$ Garnier's model for the initial ${ }^{14} \mathrm{C}$ content of dissolved inorganic carbon used in groundwater dating: Chemical Geology, v. 351, p. 105-114. [Also available at https://doi.org/10.1016/j.chemgeo.2013.05.011.]

Harvey, F.E., 2001, Use of NADP archive samples to determine isotope composition of precipitation-Characterizing meteoric input function for use in ground water studies: Ground Water, v. 39, no. 3, p. 380-390, accessed June 23, 2020, at https://doi.org/10.1111/j.1745-6584.2001 .tb02322.x.

Harvey, F.E., Ayers, J.F., and Gosselin, D.C., 2007, Ground water dependence of endangered ecosystems-Nebraska's eastern saline wetlands: Ground Water, v. 45, no. 6, p. 736-752, accessed April 14, 2020, at https://doi.org/ 10.1111/j.1745-6584.2007.00371.x.

Helgesen, J.O., Leonard, R.B., and Wolf, R.J., 1993, Hydrology of the Great Plains aquifer system in Nebraska, Colorado, Kansas, and adjacent areas: U.S. Geological Survey Professional Paper 1414-E, 81 p., accessed April 13, 2020, at https://pubs.usgs.gov/pp/1414e/report.pdf.

Helsel, D.R., Hirsch, R.M., Ryberg, K.R., Archfield, S.A., and Gilroy, E.J., 2020, Statistical methods in water resources: U.S. Geological Survey Techniques and Methods, book 4, chap. A3, 458 p., accessed July 13, 2020, at https://doi.org/ $10.3133 / \mathrm{tm} 4 \mathrm{a} 3$. [Supersedes USGS Techniques of WaterResources Investigations, book 4, chap. A3, version 1.1.]
Kalin, R.M., 2000, Radiocarbon dating of groundwater systems, chap. 4 of Cook, P.G., and Herczeg, A.L., eds., Environmental tracers in subsurface hydrology: Boston, Kluwer Academic Publishers, p. 111-144.

Kazemi, G.A., Lehr, J.H., and Perrochet, P., 2006, Groundwater age: Hoboken, N.J., John Wiley and Sons, Inc., 325 p. [Also available at https://doi.org/10.1002/ 0471929514.]

Kendall, C., and Caldwell, E.A., 1998, Fundamentals of isotope geochemistry, chap. 2 of Kendall, C., and McDonnell, J.J., eds., Isotope tracers in catchment hydrology: Amsterdam, Elsevier, p. 51-86, accessed June 23, 2020, at https://wwwrcamnl.wr.usgs.gov/isoig/isopubs/itchch2.html.

Korus, J.T., Divine, D.P., Hanson, P.R., and Dillon, J.S., 2012, Three geologic cross-sections across portions of eastern Nebraska showing Quaternary lithologic units and stratigraphy of uppermost bedrock: University of NebraskaLincoln Conservation and Survey Division Correlations and Cross sections (CCS) 18, 16 p. [Also available at ht tps://www.enwra.org/media/CCS18_Korus-Divine-HansonDillon.pdf.]

Korus, J.T., and Joeckel, R.M., 2011, Generalized geologic and hydrostratigraphic framework of Nebraska 2011, ver. 2: Lincoln, Conservation and Survey Division, University of Nebraska-Lincoln, Geologic Maps and Charts (GMC) 38.

Laukaitis, A., 2012, High and dry-The drought of 2012: Lincoln Journal Star, Lincoln, Nebr., accessed April 8, 2020, at https://journalstar.com/news/local/high-anddry-the-drought-of/article 8be43c1f-0b17-5495-8275d39bf006f80f.html.

Lindsey, B.D., Jurgens, B.C., and Belitz, K., 2019, Tritium as an indicator of modern, mixed, and premodern groundwater age: U.S. Geological Survey Scientific Investigations Report 2019-5090, 18 p., accessed August 4, 2020, at https://doi.org/10.3133/sir20195090.

Maupin, M.A., Kenny, J.F., Hutson, S.S., Lovelace, J.K., Barber, N.L., and Linsey, K.S., 2014, Estimated use of water in the United States in 2010: U.S. Geological Survey Circular 1405, 56 p. [Also available at https://doi.org/ 10.3133/cir1405.]

McGuire, V.L., Ryter, D.W., and Flynn, A.S., 2012, Altitude, age, and quality of groundwater, Papio-Missouri River Natural Resources District, eastern Nebraska, 1992 to 2009: U.S. Geological Survey Scientific Investigations Report 2012-5036, 68 p., accessed August 4, 2020, at https://doi.org/10.3133/sir20125036. 
Michel, R.L., Jurgens, B.C., and Young, M.B., 2018, Tritium deposition in precipitation in the United States, 1953-2012: U.S. Geological Survey Scientific Investigations Report 2018-5086, 11 p., accessed August 4, 2020, at https://doi.org/10.3133/sir20185086.

Miller, J.A., and Appel, C.L., 1997, Ground water atlas of the United States-Segment 3, Kansas, Missouri, and Nebraska: U.S. Geologic Survey Hydrologic Atlas 730D, 24 p. [Also available at https://doi.org/10.3133/ha730D.]

Mueller, D.K., and Helsel, D.R., 1996, Nutrients in the nation's waters-Too much of a good thing?: U.S. Geological Survey Circular 1136, 24 p. [Also available at https://doi.org/10.3133/cir1136.]

National Center for Environmental Information, 2020, 1981-2010 U.S. climate normals: Asheville, N.C., National Center for Environmental Information, digital data, accessed May 14, 2020, at https://www.ncdc.noaa.gov/cdoweb/datatools/normals.

Nebraska Department of Natural Resources, 2020, Registered groundwater wells data retrieval: Nebraska Department of Water Resources, digital data, accessed April 14, 2020, at http://nednr.nebraska.gov/Dynamic/Wells/Wells.

Parkhurst, D.L., and Charlton, S.R., 2008, NetpathXLAn Excel ${ }^{\circledR}$ interface to the program NETPATH: U.S. Geological Survey Techniques and Methods, book 6, chap. A26, 11 p., accessed June 24, 2020, at https://pubs .usgs.gov/tm/06A26/.

Parkhurst, D.L., and Plummer, L.N., 1993, Geochemical models, chap. 9 of Alley, W.M., ed., Regional ground-water quality: New York, Van Nostrand Reinhold, p. 199-225.

Piper, A.M., and Garrett, A.A., 1953, Native and contaminated ground waters in the Long Beach-Santa Ana area, California: U.S. Geological Survey Water Supply Paper 1136, 320 p. [Also available at https://doi.org/10.3133/ wsp1136.]

Smith, B.D., Abraham, J.D., Cannia, J.C., Steele, G.V., and Hill, P., 2008, Helicopter electromagnetic and magnetic geophysical survey data, Oakland, Ashland, and Firth study areas, eastern Nebraska, March 2007: U.S. Geological Survey Open-File Report 2008-1018, 31 p., 1 plate. [Also available at https://doi.org/10.3133/ofr20081018.]

Solomon, D.K., and Cook, P.G., 2000, 3H and 3He, chap. 13 of Cook, P.G., and Herczeg, A.L., eds., Environmental tracers in subsurface hydrology: Boston, Kluwer Academic Publishers, p. 442-478.

Stotler, R.L., 2000, Isotopic evidence for Pleistocene recharge in the Dakota aquifer, northeast Nebraska: University of Nebraska-Lincoln, School of Natural Resources, B.S. Thesis, $72 \mathrm{p}$.
Stotler, R.L., Harvey, F.E., and Gosselin, D.C., 2010, A Black Hills-Madison aquifer origin for Dakota aquifer groundwater in northeastern Nebraska: Ground Water, v. 48, no. 3 , p. 448-464, accessed April 23, 2020, at https://doi.org/ 10.1111/j.1745-6584.2009.00636.x.

Struzeski, T.M., DeGiacomo, W.J., and Zayhowski, E.J., 1996, Methods of analysis by the U.S. Geological Survey National Water Quality Laboratory-Determination of dissolved aluminum and boron in water by inductively coupled plasma-atomic emission spectrometry: U.S. Geological Survey Open-File Report 96-149, 17 p. [Also available at https://doi.org/10.3133/ofr96149.]

Tanner, D.Q., and Steele, G.V., 1991, Ground-water quality in the Nemaha Natural Resources District, southeastern Nebraska, 1989: U.S. Geological Survey Water Resources Investigations Report 90-4184, 52 p., accessed April 9, 2020, at https://doi.org/10.3133/wri904184.

U.S. Environmental Protection Agency, 2018, 2018 Edition of the drinking water standards and health advisories: Office of Water, U.S. Environmental Protection Agency, Fact Sheet EPA 822-F-18-001, accessed February 21, 2021, at https://www.epa.gov/sites/production/files/2018-03/ documents/dwtable2018.pdf.

U.S. Geological Survey, variously dated, National field manual for the collection of water-quality data: U.S. Geological Survey Techniques of Water-Resources Investigations, book 9, chaps. A1-A9, [variously paged]. [Also available at https://water.usgs.gov/owq/FieldManual/.]

U.S. Geological Survey, 2020a, Dissolved oxygen: U.S. Geological Survey Techniques and Methods, book 9, chap. A6.2, 33 p. [Also available at https://doi.org/10.3133/ tm9A6.2.] [Supersedes USGS Techniques of WaterResources Investigations, book 9, chap. A6.2, version 3.0.]

U.S. Geological Survey, 2020b, USGS water data for the Nation: U.S. Geological Survey National Water Information System database, accessed June 18, 2020, at https://doi.org/ 10.5066/F7P55KJN.

U.S. Geological Survey, 2020c, Menlo Park Tritium Laboratory: U.S. Geological Survey Web site, accessed June 19, 2020, at https://water.usgs.gov/nrp/menlo-parktritium-laboratory/.

U.S. Geological Survey, 2020d, Reston Stable Isotope Laboratory (RSIL): U.S. Geological Survey Web site, accessed June 19, 2020, at https://isotopes.usgs.gov/lab/ methods.html. 
Verstraeten, I.M., and Ellis, M.J., 1995, Reconnaissance of ground-water quality in the Papio-Missouri River Natural Resources District, eastern Nebraska, July through September 1992: U.S. Geological Survey Water-Resources Investigations Report 94-4197, 90 p, accessed April 9, 2020, at https://doi.org/10.3133/wri944197.

Wang, Y., Huntington, T.G., Osher, L.J., Wassenaar, L.I., Trumbore, S.E., Amundson, R.G., Harden, J.W., McKnight, D.M., Schiff, S.L., Aiken, G.R., Lyons, W.B., Aravena, R.O., and Baron, J.S., 1998, Carbon cycling in terrestrial environments, chap. 17 of Kendall, C., and McDonnell, J.J., eds., Isotope tracers in catchment hydrology: Amsterdam, Elsevier Publications, p. 577-610.
Woods Hole Oceanographic Institution, 2020, Woods Hole Oceanographic Institution Accelerator Mass Spectrometry: Woods Hole Oceanographic Institution website, accessed June 19, 2020, at https://www.whoi.edu/nosams/home.

YSI Incorporated, 2020, YSI 556 Operations MPS Manual: Yellow Springs, Ohio, YSI Incorporated, accessed September 16, 2020, at https://www.ysi.com/File\%20 Library/Documents/Manuals/655279-YSI-556-OperationsManual-RevD.pdf. 
For more information about this publication, contact: Director, USGS Nebraska Water Science Center 5231 South 19th Street

Lincoln, NE 68512

402-328-4100

For additional information, visit: https://www.usgs.gov/ centers/ne-water

Publishing support provided by the

Rolla Publishing Service Center 


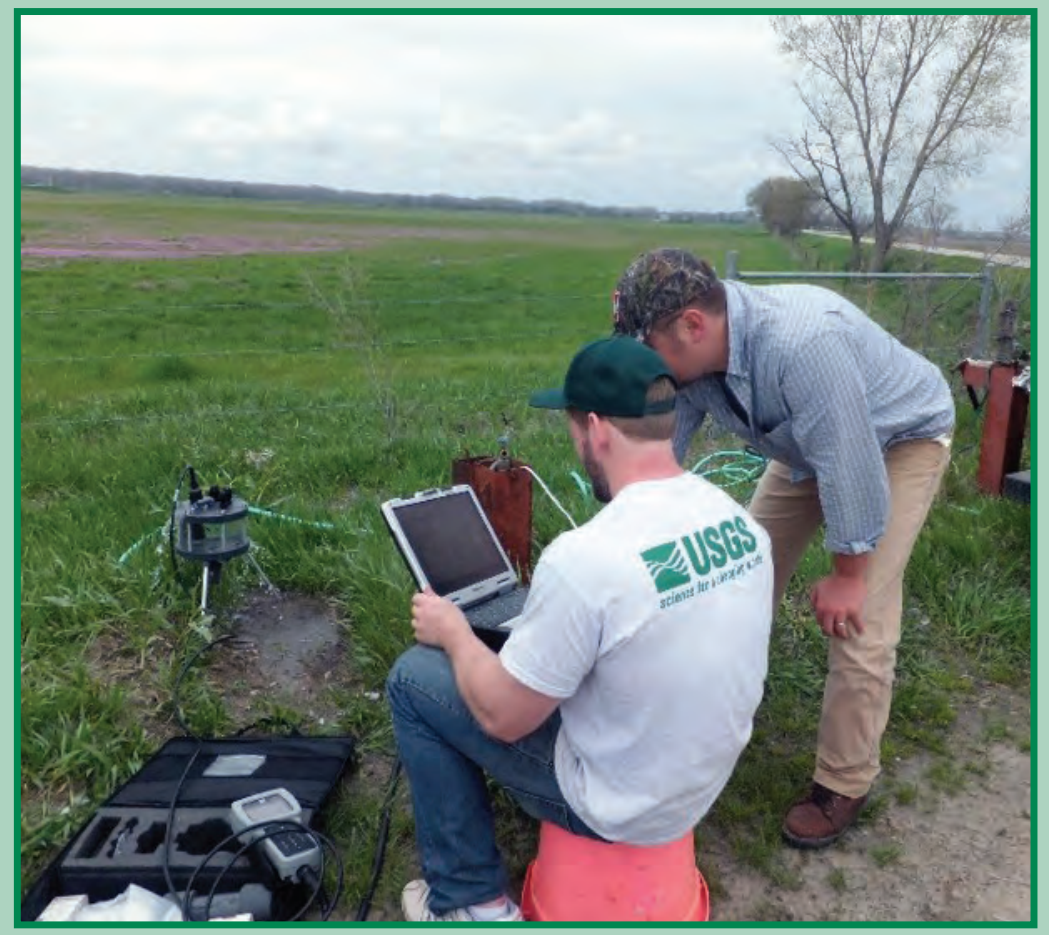

